\title{
Chemistry of Runoff and Shallow Ground Water at the Cattlemans Detention Basin Site, South Lake Tahoe, California, August 2000 - November 2001
}

Scientific Investigations Report 2004-5254

Prepared in cooperation with the EL DORADO COUNTY DEPARTMENT OF TRANSPORTATION, TAHOE ENGINEERING DIVISION 


\section{(Back of Cover)}




\section{Chemistry of Runoff and Shallow Ground Water at the Cattlemans Detention Basin Site, South Lake Tahoe, California, August 2000 - November 2001}

By David E. Prudic, Sienna J. Sager, James L. Wood, Katherine K. Henkelman, and Rachel M. Caskey

U.S. GEOLOGICAL SURVEY

Scientific Investigations Report 2004-5254

Prepared in cooperation with the EL DORADO COUNTY DEPARTMENT OF TRANSPORTATION, TAHOE ENGINEERING DIVISION 


\title{
U.S. DEPARTMENT OF THE INTERIOR GALE A. NORTON, Secretary
}

\author{
U.S. GEOLOGICAL SURVEY \\ CHARLES G. GROAT, Director
}

Any use of trade, product, or firm names in this publication is for descriptive

purposes only and does not imply endorsement by the U.S. Government

For additional information

contact:

District Chief

U.S. Geological Survey

333 West Nye Lane, Room 203

Carson City, NV 89706-0866

Email: GS-W-NVpublic-info @ usgs.gov

$<$ http://nevada.usgs.gov>
For more information about the U.S. Geological Survey and its products:

<http://www.usgs.gov>

Telephone: 1-888-ASK-USGS 


\section{CONTENTS}

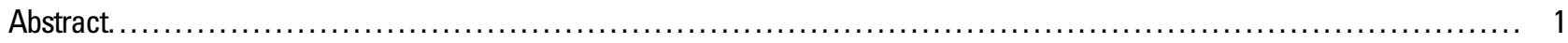

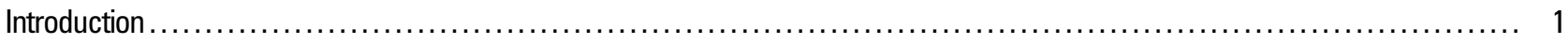

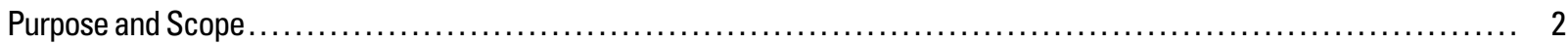

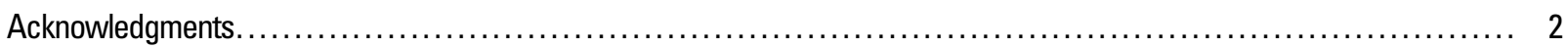

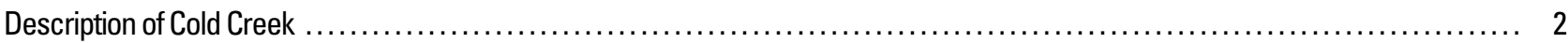

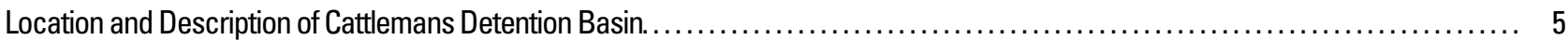

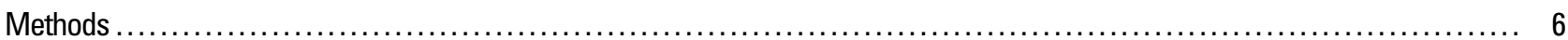

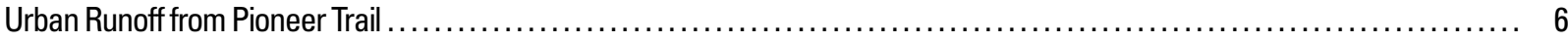

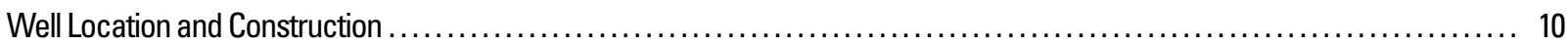

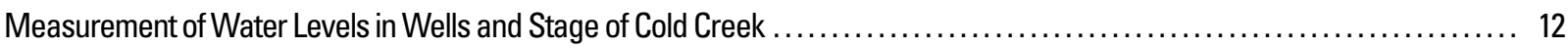

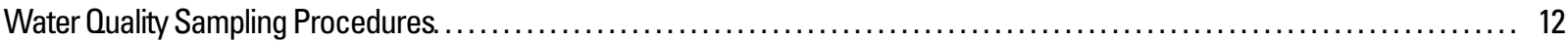

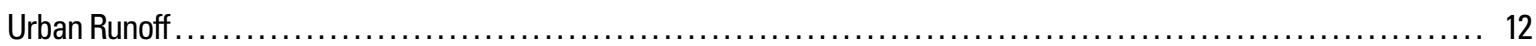

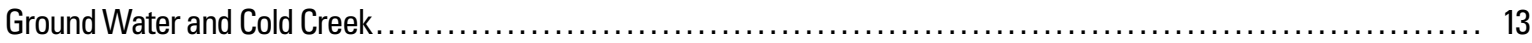

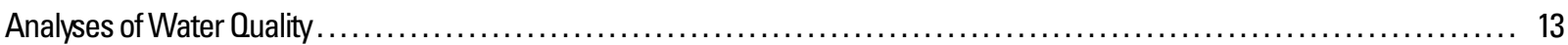

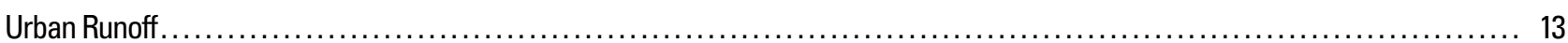

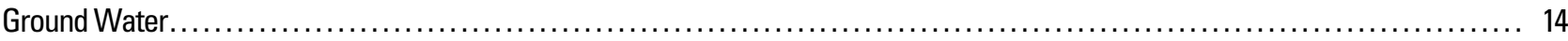

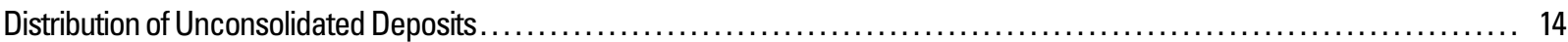

Direction of Ground-Water Flow. . . . . . . .

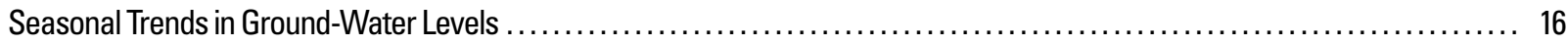

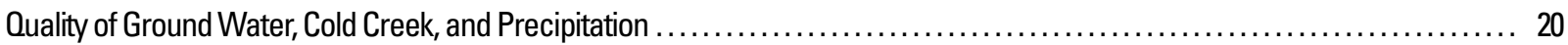

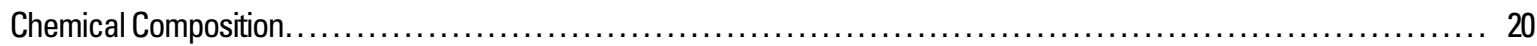

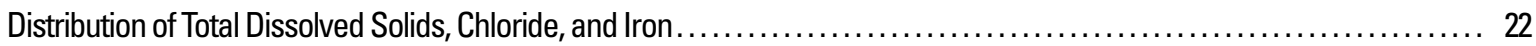

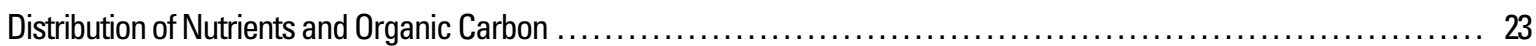

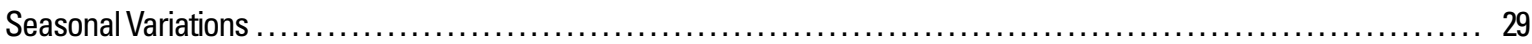

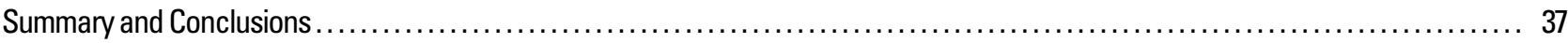

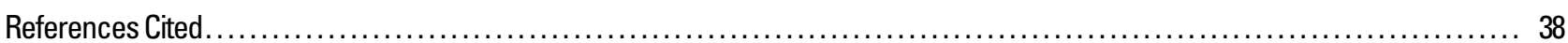

\section{FIGURES}

1. Map showing location of Lake Tahoe and study area adjacent to Cold Creek, South Lake Tahoe, California............... 3

2. Aerial view showing different channels of Cold Creek near Cattlemans detention basin prior to its construction............ 4

3. Photographs showing Cold Creek in January 2001 at the first meander adjacent to Cattlemans detention basin prior to its construction, and Cold Creek in May 2001 downstream of detention basin prior to its construction. ............... 5

4. Drawing of Cattlemans detention basin in relation to Cold Creek, Pioneer Trail, and Cattlemans Court, and location of

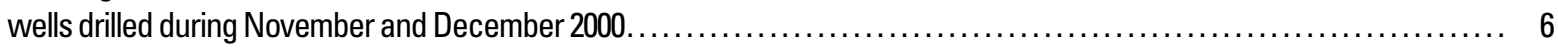

5. Aerial view showing location of areas that contributed runoff to the area of the planned Cattlemans detention basin prior

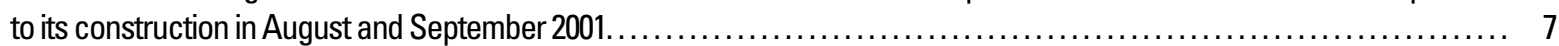

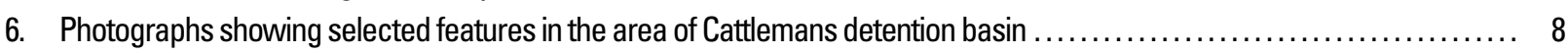

7. Diagram showing construction of wells in the area of Cattlemans detention basin ............................ 12

8. Vertical section showing distribution of shallow unconsolidated deposits beneath Cattlemans detention basin prior to its

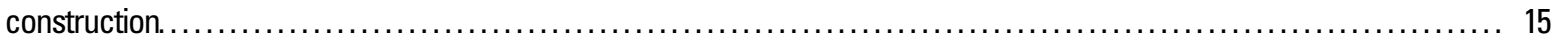

9. Graphs showing time-distance curves and velocity-depth profile for seismic-refraction line $A-A$ 'near Cattlemans

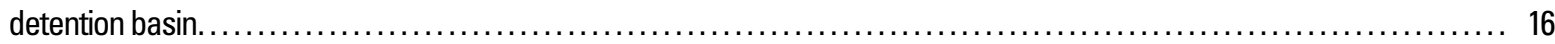

10. Drawing of ground-water level contours for May 2001 in the area of Cattlemans detention basin prior to its construction.... 17 
11. Graphs showing trends of ground-water levels in wells with recording pressure transducers in the area of Cattlemans detention basin prior to and during its construction in relation to precipitation and air temperature, January through

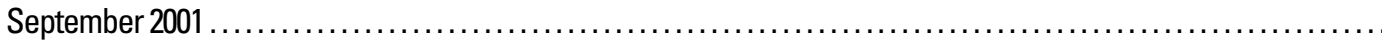

12. Graphs showing trends of ground-water levels from periodic measurements in wells without recording pressure transducers in the area of Cattlemans detention basin prior to and during its construction, December 2000 through October 2001 .....

13. Graph showing relation between stage of Cold Creek and ground-water level at well cc14 on west side of Cattlemans detention basin prior to and during its construction, June through September 2001.

14. Graph showing relation between total dissolved solids and dissolved chloride and bromide in ground water in the area of Cattlemans detention basin prior to and during its construction, January to November 2001.

15. Drawing of distribution of total dissolved solids, dissolved chloride, and dissolved iron in ground water from meadow deposits in the area of Cattlemans detention basin prior to its construction, late April and May 2001 .

16. Vertical sections showing distribution of total dissolved solids, dissolved chloride, and dissolved iron in ground water beneath Cattlemans detention basin prior to its construction, late April and May 2001

17. Drawing of distribution of dissolved ammonia plus organic nitrogen, dissolved phosphorus, and dissolved organic carbon in ground water from meadow deposits in the area of Cattlemans detention basin prior to its construction, late April and May 2001.

18. Vertical sections showing distribution of dissolved ammonia plus organic nitrogen, dissolved phosphorus, and dissolved organic carbon in ground water beneath Cattlemans detention basin prior to its construction, late April and May 2001 ...... 33

19. Graph showing relation between the mean concentration of dissolved organic carbon to mean concentration of total dissolved nitrogen in ground-water samples from the area of Cattlemans detention basin prior to and during its construction, January to November 2001.

20. Graphs showing trends of major dissolved constituents in ground water from meadow deposits in the area of Cattlemans detention basin prior to and during its construction, January to November 2001.

21. Graphs showing trends of major dissolved constituents in ground water from deeper sand and gravel in the area of Cattlemans detention basin prior to and during its construction, January to November 2001

22. Graphs showing trends of dissolved nitrogen and phosphorus in ground water from meadow deposits in the area of Cattlemans detention basin prior to and during its construction, January to November 2001

23. Graphs showing trends of dissolved nitrogen and phosphorus in ground water from deeper sand and gravel in the area of Cattlemans detention basin prior to and during its construction, January to November 2001

24. Graphs showing trends of dissolved organic carbon in ground water in the area of Cattlemans detention basin prior to and during its construction, January to November 2001

\section{TABLES}

1. Well name, land-surface altitude, and construction data for wells in the area of Cattlemans detention basin, South Lake Tahoe, California.

2. Duration, total volume, nutrient mass, and total suspended solids of urban runoff from Pioneer Trail and Montgomery

Estates subdivision, August 2000 to March 2001. . ...

3. Median and mean concentrations of dissolved constituents in ground water and in Cold Creek in the area of Cattlemans detention basin prior to and during its construction, South Lake Tahoe, California, and in perennial and ephemeral springs in granitic rocks and snow in the Sierra Nevada.

4. Concentrations of principal dissolved inorganic constituents and dissolved organic carbon in ground water in the area of Cattlemans detention basin prior to and during its construction, South Lake Tahoe, California, January to November 2001... 23

5. Concentrations of dissolved inorganic trace elements in ground water in the area of Cattlemans detention basin prior to and after its construction, South Lake Tahoe, California, January to November 2001

6. Concentrations of dissolved nutrients in ground water in vicinity of Cattlemans detention basin prior to and during its construction, South Lake Tahoe, California, January to November 2001. 
CONVERSION FACTORS AND VERTICAL DATUM

\begin{tabular}{|c|c|c|}
\hline Multiply & By & To obtain \\
\hline \multicolumn{3}{|c|}{ Length } \\
\hline inch (in.) & 25.4 & millimeter \\
\hline foot $(\mathrm{ft})$ & 0.3048 & meter \\
\hline mile (mi) & 1.609 & kilometer \\
\hline \multicolumn{3}{|c|}{ Area } \\
\hline square foot $\left(\mathrm{ft}^{2}\right)$ & 0.09290 & square meter \\
\hline square mile $\left(\mathrm{mi}^{2}\right)$ & 2.590 & square kilometer \\
\hline \multicolumn{3}{|c|}{ Volume } \\
\hline quart (qt) & 0.9464 & liter \\
\hline gallon (gal) & 3.785 & liter \\
\hline cubic foot $\left(\mathrm{ft}^{3}\right)$ & 0.02832 & cubic meter \\
\hline \multicolumn{3}{|c|}{ Flow rate } \\
\hline foot per second $(\mathrm{ft} / \mathrm{s})$ & 0.3048 & meter per second \\
\hline cubic foot per second $\left(\mathrm{ft}^{3} / \mathrm{s}\right)$ & 0.02832 & cubic meter per second \\
\hline \multicolumn{3}{|c|}{ Mass } \\
\hline ounce, avoirdupois (oz) & 28.35 & gram \\
\hline pound, avoirdupois (lb) & 0.4536 & kilogram \\
\hline
\end{tabular}

Temperature: Degrees Celsius $\left({ }^{\circ} \mathrm{C}\right)$ can be converted to degrees Fahrenheit $\left({ }^{\circ} \mathrm{F}\right)$ by using the formula ${ }^{\circ} \mathrm{F}=\left[1.8\left({ }^{\circ} \mathrm{C}\right)\right]+32$. Degrees Fahrenheit can be converted to degrees Celsius by using the formula ${ }^{\circ} \mathrm{C}=0.556\left({ }^{\circ} \mathrm{F}-32\right)$.

Sea level: In this report, "sea level" refers to the National Geodetic Vertical Datum of 1929 (NGVD of 1929, formerly called "Sea-Level Datum of 1929"), which is derived from a general adjustment of the first-order leveling networks of the United States and Canada.

Horizontal coordinate information is referenced to North American Datum of 1983 (NAD 1983).

Specific conductance is given in microsiemens per centimeter at 25 degrees Celsius $\left(\mu \mathrm{S} / \mathrm{cm}\right.$ at $\left.25^{\circ} \mathrm{C}\right)$.

Concentrations of chemical constituents in water are given in milligrams per liter $(\mathrm{mg} / \mathrm{L})$ or micrograms per liter $(\mu \mathrm{g} / \mathrm{L})$. 



\title{
Chemistry of Runoff and Shallow Ground Water at the Cattlemans Detention Basin Site, South Lake Tahoe, California, August 2000 - November 2001
}

\author{
By David E. Prudic, Sienna J. Sager, James L. Wood, Katherine K. Henkelman, and Rachel M. Caskey
}

\section{Abstract}

A study at the Cattlemans detention basin site began in November 2000. The site is adjacent to Cold Creek in South Lake Tahoe, California. The purpose of the study is to evaluate the effects of the detention basin on ground-water discharge and changes in nutrient loads to Cold Creek, a tributary to Trout Creek and Lake Tahoe. The study is being done in cooperation with the Tahoe Engineering Division of the El Dorado County Department of Transportation. This report summarizes data collected prior to and during construction of the detention basin and includes: (1) nutrient and total suspended solid concentrations of urban runoff; (2) distribution of unconsolidated deposits; (3) direction of ground-water flow; and (4) chemistry of shallow ground water and Cold Creek.

Unconsolidated deposits in the area of the detention basin were categorized into three classes: fill material consisting of a red-brown loamy sand with some gravel and an occasional cobble that was placed on top of the meadow; meadow deposits consisting of gray silt and sand with stringers of coarse sand and fine gravel; and a deeper brown to yellow-brown sand and gravel with lenses of silt and sand. Prior to construction of the detention basin, ground water flowed west-northwest across the area of the detention basin toward Cold Creek. The direction of ground-water flow did not change during construction of the detention basin.

Median concentrations of dissolved iron and chloride were 500 and 30 times higher, respectively, in ground water from the meadow deposits than dissolved concentrations in Cold Creek. Median concentration of sulfate in ground water from the meadow deposits was 0.4 milligrams per liter and dissolved oxygen was below the detection level of 0.3 milligrams per liter. The lack of oxygen in the shallow ground water likely is caused by microbial oxidation of organic matter. The higher chloride concentrations in ground water compared with Cold Creek likely are caused from the application of salt on Pioneer Trail and streets in Montgomery Estates subdivision during the winter. Runoff from these roads contributes to the recharge of the shallow ground water. The range of dissolved constituents generally was greater in the meadow deposits than in the deeper sand and gravel.
Ammonia plus organic nitrogen were the dominant forms of dissolved nitrogen and concentrations ranged from 0.04 to 18 milligrams per liter as nitrogen. Highest concentration was beneath the middle of the detention basin. Nitrate plus nitrite concentrations were low ( $<0.33$ milligrams per liter as nitrogen) throughout the area and dissolved phosphorus concentrations ranged from 0.001 to 0.34 milligrams per liter. Nitrogen and dissolved organic carbon showed no consistent pattern in the direction of ground-water flow, which suggests that, similar to iron and sulfate, local variations in the chemical and biological reactions within the meadow deposits controlled the variation in nitrogen concentrations. The gradual increase in dissolved phosphorus along the direction of ground-water flow suggest that phosphorus may be slowly dissolving into ground water. Dissolved phosphorus was consistently low in July, which may be the result of greater microbial activity in the unconsolidated deposits or from uptake by roots during the summer.

\section{Introduction}

Lake Tahoe is a beautiful high alpine lake and a popular vacation destination. The lake is located on the State line of Nevada and California near the crest of the Sierra Nevada, about 150 mi northeast of San Francisco (fig. 1). Lake Tahoe is remarkable in its size, depth, and clarity, and it is considered by many to rank amongst the world's most beautiful scenes (Crippen and Pavelka, 1970). Unfortunately, Lake Tahoe's clarity has been decreasing (Goldman, 1988). The decrease in clarity has been attributed to increased sediments and nutrients in surface water entering the lake as a result of human activity (Crippen and Pavelka, 1970; Glancy, 1988; and Goldman, 1988; Goldman and Byron, 1986).

Maintaining Lake Tahoe's beauty continues to be a priority for the states of California and Nevada as well as the Federal Government. Additionally, the Clean Water Act greatly affected transportation agencies by requiring implementation of wetland mitigation and urban detention basins in response to provisions of the act ( $\mathrm{Yu}$ and others, 1998). Numerous detention basins have been constructed in the Lake Tahoe Basin (Fenske, 1990; Reuter and others, 1992b) in response to the Clean Water Act and to help maintain Lake Tahoe's clarity. 


\section{Chemistry of Runoff and Shallow Ground Water at the Cattlemans Detention Basin Site, South Lake Tahoe, California}

Constructing wetlands in or adjacent to urban detention basins have improved the quality of urban runoff (Scherger and Davis, 1982; Martin, 1986; Reuter and others, 1992a; and Reuter and others, 1992b; Hydro Science, 2000, p. 44). Conversely, the potential exists for degrading water quality in ground water beneath the detention basins and associated wetlands (K.B. Foster Civil Engineers, Inc.,1989; Church and Friesz, 1993; Granato and others, 1995).

This study is being done in cooperation with the El Dorado County Department of Transportation, Tahoe Engineering Division (TED). TED started data collection in 1999 through a Tahoe Keys Mitigation Grant. The cooperative study began in November 2000, ten months prior to actual construction of the detention basin. Through funding from California Tahoe Conservancy, El Dorado County entered into a joint funding agreement with the U.S. Geological Survey (USGS) to continue the study through 2006.

\section{Purpose and Scope}

The purpose of the study is to evaluate the effects of Cattlemans detention basin on ground-water discharge and changes in nutrient and sediment loads to Cold Creek, a tributary to Trout Creek and Lake Tahoe. Cattlemans detention basin is along Pioneer Trail in South Lake Tahoe, California (fig. 1). The detention basin was constructed in August and September 2001 as part of the El Dorado County Pioneer Trail III Erosion Control and Bike Lane Project.

The scope of the project is to: (1) estimate the quantity of urban runoff that enters and exits the detention basin along with estimates of total nutrient and suspended sediment loads;

(2) estimate ground-water flow before and after construction of the detention basin; and (3) evaluate changes in nutrient loads that may enter Cold Creek from increased ground-water flow as the result of the detention basin. The overall project includes about one year of data collection prior to construction of the detention basin and four years of data collection after construction.

This report summarizes data collected prior to and during construction of the detention basin and includes: (1) nutrient and total suspended solid concentrations of urban runoff collected between August 2000 and March 2001; (2) description of unconsolidated deposits determined from the drilling of 30 monitoring wells in November and December 2000; (3) analysis of the direction of ground-water flow between January 2001 and November 2001; and (4) chemistry of shallow ground water and Cold Creek between January 2001 and November 2001. Data on urban runoff from Pioneer Trail and the adjoining Montgomery Estates subdivision and data on ground-water levels and water quality were collected prior to construction of the detention basin to provide a basis for evaluating changes caused by the detention basin. Although the detention basin was constructed during August and September 2001 , four ground-water samples from wells adjacent to the detention basin were not sampled until November 2001. These wells were sampled at a later date because access to them was difficult during construction of the detention basin. The samples are included with the preconstruction data for continuity with samples collected from other wells in September 2001.

The flow-proportional sampler used to monitor flow and to collect urban samples from Pioneer Trail and parts of adjacent Montgomery Estates was installed and maintained by the TED. The USGS measured the stage in Cold Creek, installed monitoring wells, identified the unconsolidated deposits in the subsurface, measured water levels, and collected water samples from monitoring wells and from Cold Creek.

\section{Acknowledgments}

Many employees from the TED participated in this study. David Friestad designed the Pioneer Trail III Erosion Control and Bike Lane Project where the Cattlemans detention basin is located. Troy Alexander installed and operated the portable automatic flow meters and samplers in a culvert along Pioneer Trail prior to construction of the detention basin. The sampler captured urban runoff from part of Montgomery Estates subdivision and Pioneer Trail. Initially, the flow meter and sampler was loaned to the TED by Vernon Finney from the Department of Agriculture, National Resource Conservation Service, Davis, California. Clayton Chappell and Janel Gifford from the TED and Kimberly Carr from the California Tahoe Conservancy were instrumental in developing the work plan and in securing funding for this study. Troy Alexander, Clayton Chappell, Eric Prouty, and Jennifer Quickel of TED assisted with data collection. Finally, precipitation and temperature data used in this report was provided by Russell Wigart, Assistant Engineer with the City of South Lake Tahoe.

\section{Description of Cold Creek}

The headwater area of Cold Creek is in the mountains south of Lake Tahoe. The creek flows northwest until it joins Trout Creek about 3.6 mi from Lake Tahoe (fig. 1). Cold Creek is the largest watershed tributary to Trout Creek. The drainage area of Cold Creek is $12.8 \mathrm{mi}^{2}$ (Rowe and Allander, 2000, p. 8). Upstream of Pioneer Trail, the drainage is largely undeveloped and is underlain by granodiorite that is covered in places by glacial deposits (Bonham and Burnett, 1976). Cold Creek enters a large meadow where Pioneer Trail crosses the creek about $0.6 \mathrm{mi}$ above its confluence with Trout Creek. 


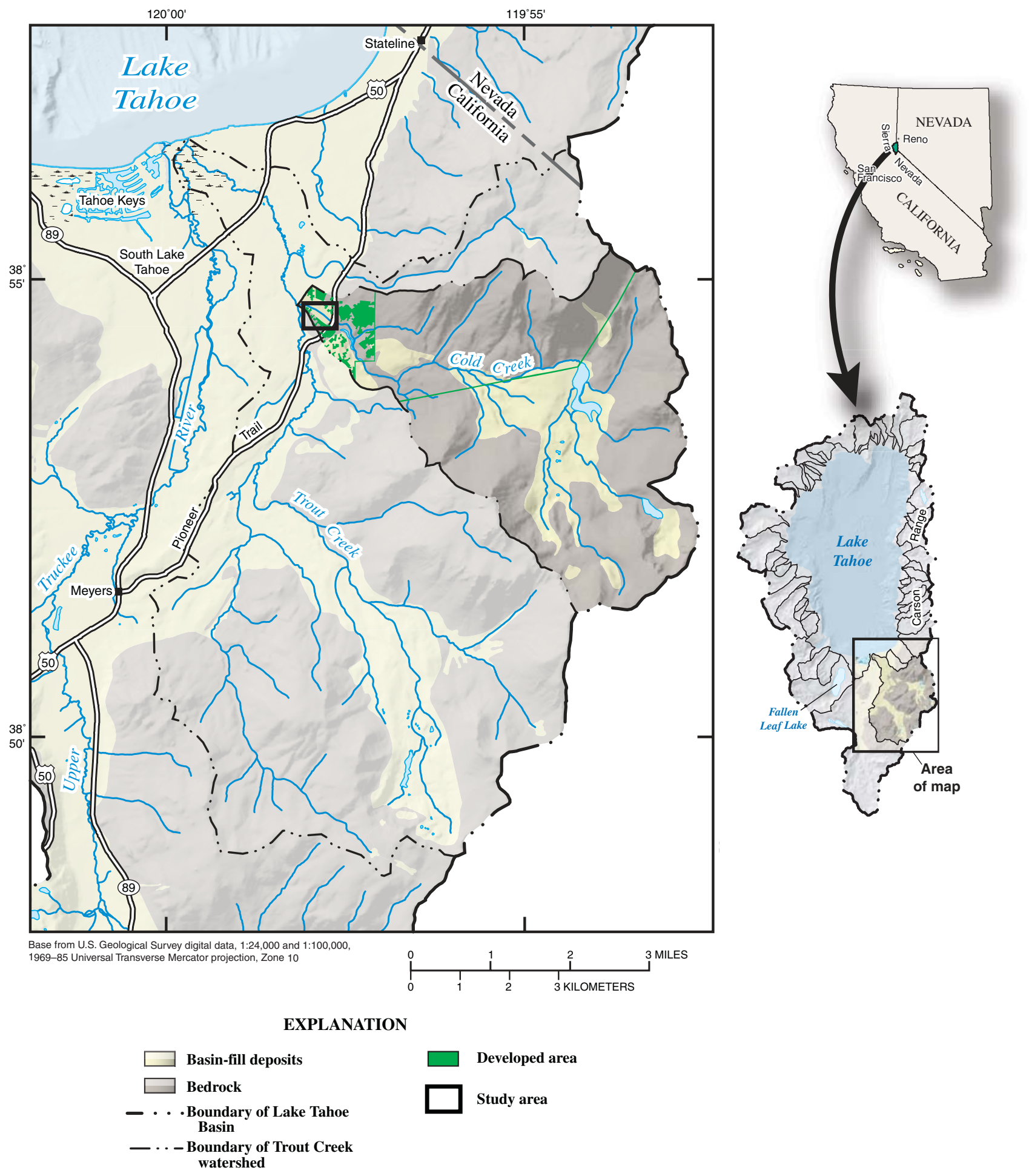

Figure 1. Location of Lake Tahoe and study area adjacent to Cold Creek, South Lake Tahoe, California (modified from Allander, 2003). 


\section{Chemistry of Runoff and Shallow Ground Water at the Cattlemans Detention Basin Site, South Lake Tahoe, California}

Cold Creek and the meadow have undergone several changes since the early 1950's (fig. 2). Prior to the development of the surrounding area, Cold Creek flowed through the meadow in a relatively small and shallow channel. The channel likely did not extend far below the water table; rather the channel bottom in the sandy deposits was controlled by the groundwater level, which in the meadow, is only a few feet below land surface. During periods of high flow, usually in the spring and early summer, the creek would leave its banks and flow across the meadow, which effectively filtered the sediment from the water.

By 1969, a small dam had been constructed across the 1954 channel of Cold Creek about midway between Pioneer Trail and its confluence with Trout Creek, which created Lake Christopher (fig. 2). Sometime between 1969 and 1987 a ditch was excavated along the northern edge of the meadow. The ditch was used to both divert flow around Lake Christopher and to supply flow to the lake.

The dam was removed and the channel of Cold Creek was reconstructed in 1994 into its present form (fig. 2; Kimberly Carr, California Tahoe Conservancy, oral commun., 2003). The reconstructed channel is wider and deeper than the natural channel and has a greater sinuosity. The channel was designed to contain most of the flow within its banks (fig. $3 A$ ). The excavation of the channel below the water table and the creation of meanders that cross the direction of ground-water flow in the meadow likely increased ground-water exchange with the creek as compared to the exchange with the natural channel. The increased ground-water exchange may in part be responsible for bank instability and erosion along the channel (fig. $3 B$ ), particularly along meanders that are perpendicular to the slope of the meadow (see fig. 2).

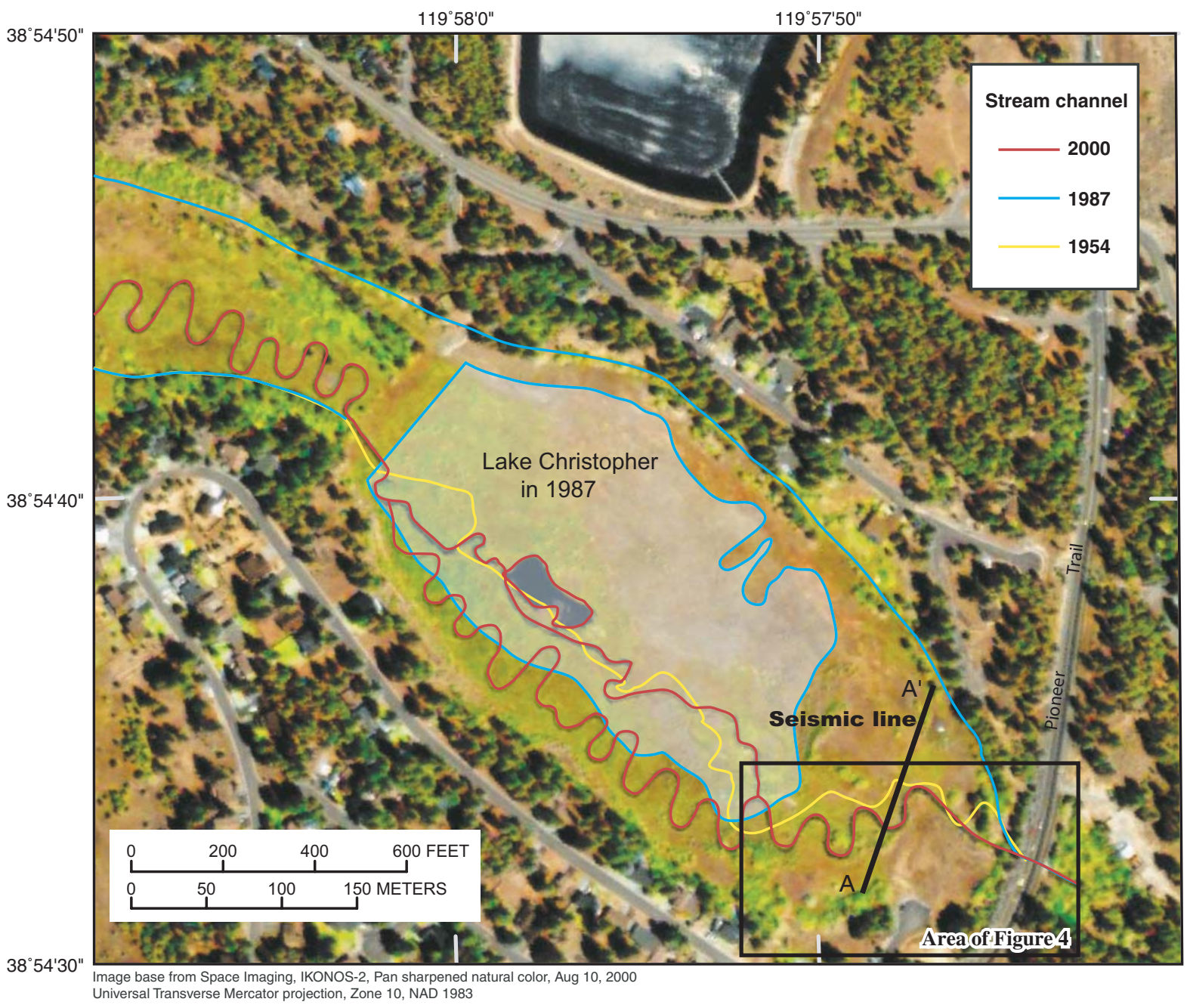

Figure 2. Different channels of Cold Creek near Cattlemans detention basin prior to its construction, South Lake Tahoe, California on three dates between 1954 and 2000 and seismic-refraction line $A-A$ ' used to determine thickness of unconsolidated deposits. 

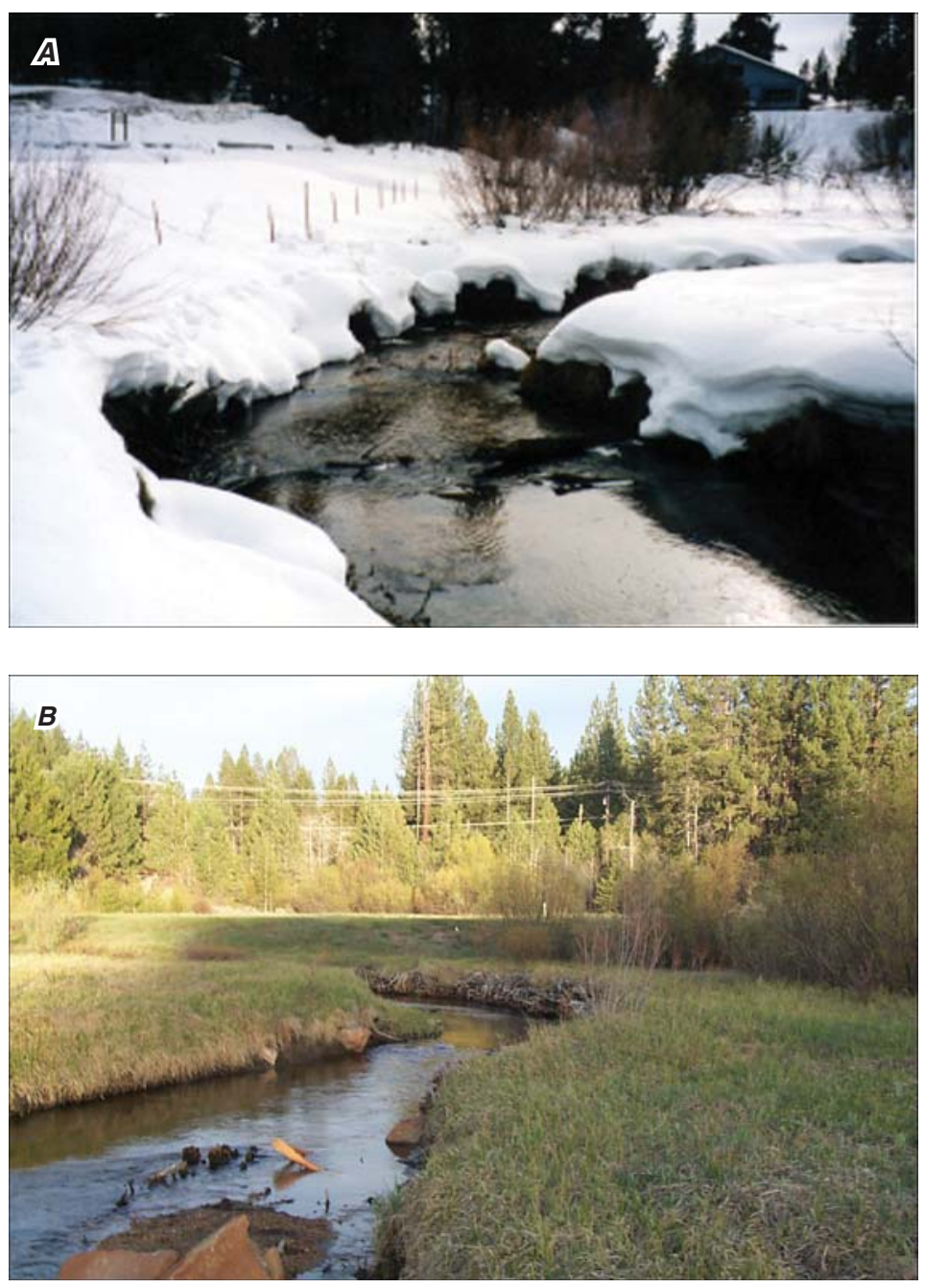

Figure 3. Photographs showing $(A)$ Cold Creek in January 2001 at the first meander adjacent to Cattlemans detention basin prior to its construction, and $(B)$ Cold Creek in May 2001 downstream of detention basin prior to its construction, South Lake Tahoe, California. Photograph $(B)$ shows a plastic pipe and large boulders that are stained orange indicating precipitation of iron on the streambed.

\section{Location and Description of Cattlemans Detention Basin}

Cattlemans detention basin is located at the end of Cattlemans Court cul-de-sac and is bordered by Pioneer Trail to the east and Cold Creek to the north and west (fig. 4). Construction began in late August 2001 and ended in late September 2001.

Prior to construction of the detention basin, urban runoff from part of Montgomery Estates flowed through a culvert on the west side of Pioneer Trail and discharged into Cold Creek through a shallow ditch excavated along the base of Pioneer Trail (fig. 5). Runoff from a small area along the east side of Pioneer Trail entered Cold Creek through a small gully on the southeast side. Once in the gully, the runoff discharged into an abandoned meander of Cold Creek that joined the active channel just upstream from the culvert beneath Pioneer Trail (fig. 5). Runoff from Cattlemans Court and from part of Montgomery Estates subdivision flowed into a storm drain at the north edge of the cul-de-sac, where it flowed north through a short section of culvert before it discharged to the surface of a large flat area. Runoff generally flowed northwest on the large flat area (fig. 5). The large flat area (fig. 6A) at the end of Cattlemans Court was constructed during development of the adjacent subdivision when 4 to $5 \mathrm{ft}$ of fill was placed on top of the meadow. Following completion of the detention basin, runoff from these three areas were rerouted into Cattlemans detention basin through a series of buried culverts (fig. 4). 

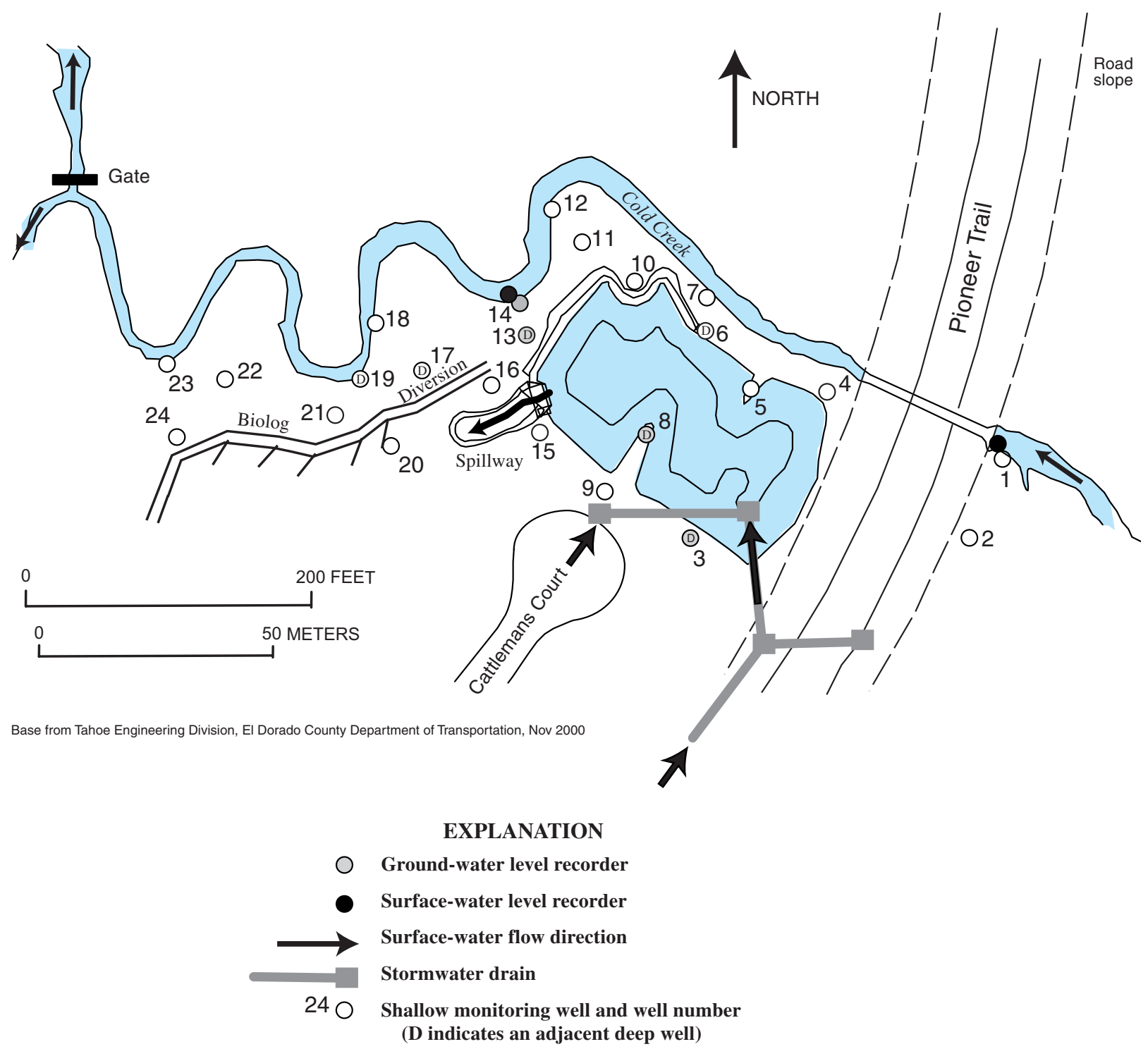

Figure 4. Cattlemans detention basin in relation to Cold Creek, Pioneer Trail, and Cattlemans Court, and location of wells drilled during November and December 2000. Well name listed in table 1 has been abbreviated by omitting the "cc" designation.

The unlined detention basin was constructed to hold a total volume of 22,000 $\mathrm{ft}^{3}$ without surface discharge (Jennifer Quickel, Tahoe Engineering Division, El Dorado County Department of Transportation, written commun., 2003). Much of the fill that had been placed in the area was removed during excavation of the detention basin (fig. 6B). A spillway was constructed of concrete with large boulders on the west side of the detention basin (fig. 6C). Overflow from the detention basin is routed through the spillway and apron into the adjacent meadow. The capacity of the basin when the spillway is at the maximum altitude of 6,276 $\mathrm{ft}$ is $28,500 \mathrm{ft}^{3}$ (Jennifer Quickel, written commun., 2003). Flow into the meadow is retained behind bundled straw (referred to as a biolog) to prevent overflow from the detention basin directly reaching Cold Creek (fig. $6 D$ ).

\section{Methods}

\section{Urban Runoff from Pioneer Trail}

Urban runoff from Pioneer Trail was monitored in a culvert on the west side of Pioneer Trail prior to construction of the detention basin. A portable automatic flow meter and sampler (ISCO 6700 provided by the National Resources Conservation Service) was installed in the culvert at an access location on the west side of Pioneer Trail in April 2000. The sampler was replaced in April 2001 with an American Sigma sampler (900MAX) and flow meter (950). The pump on the American Sigma is a high speed peristaltic, dual roller that uses a 3/8 in. inside diameter by $5 / 8 \mathrm{in}$. outside diameter medical grade 

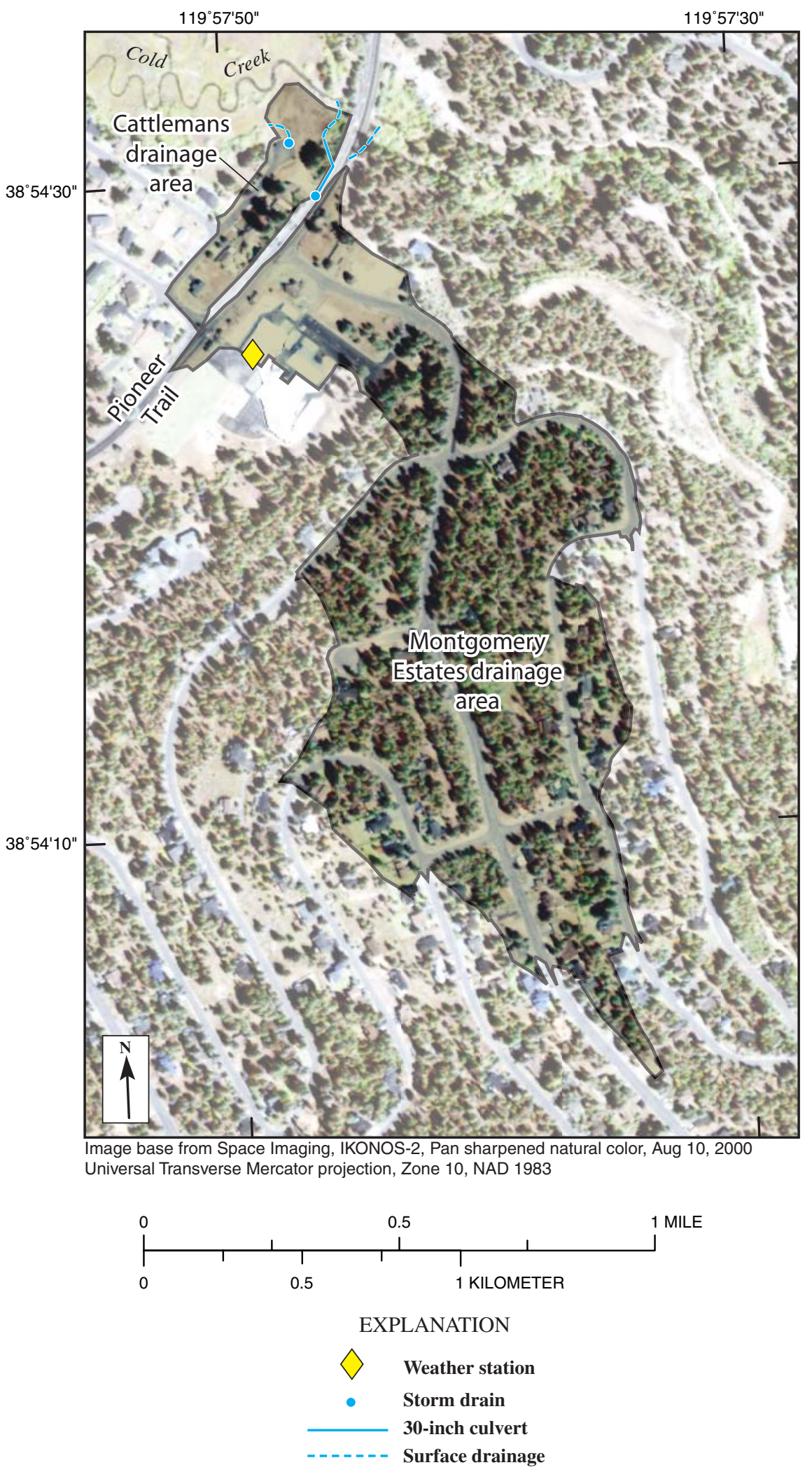

Figure 5. Location of areas that contributed runoff to the area of the planned Cattlemans detention basin prior to its construction in August and September 2001. 

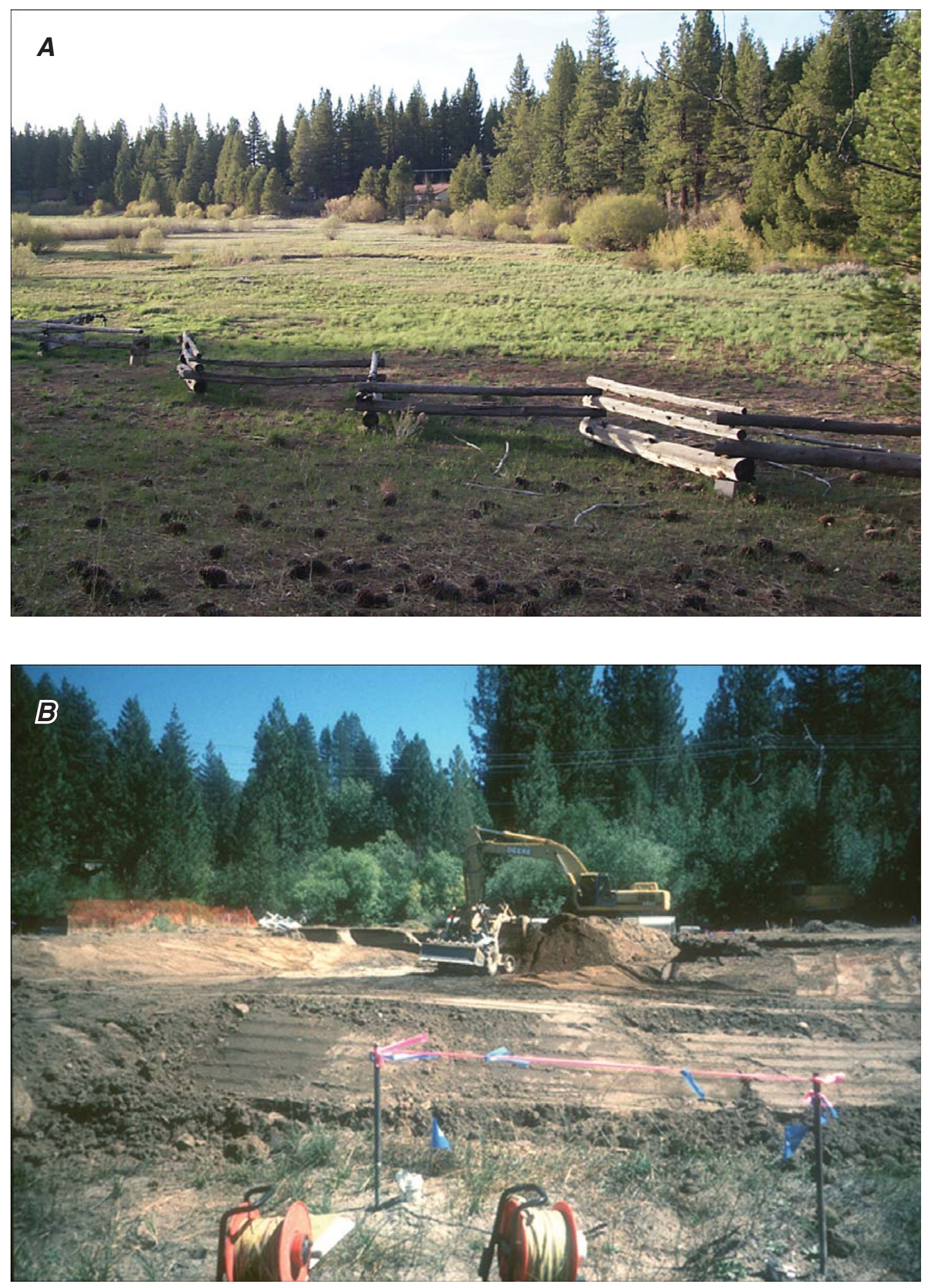

Figure 6. Photographs showing selected features in the area of Cattlemans detention basin: $(A)$ May 2001, view looking northwest across large flat area at end of Cattlemans Court prior to construction of detention basin; (B) September 2001, view looking east across flat area from well cc13 during construction of detention basin; (C) March 2002, view looking south across spillway structure of detention basin to Cattlemans Court; and (D) March 2002, view looking west from the spillway across meadow showing biolog used to keep overflow from entering Cold Creek. 

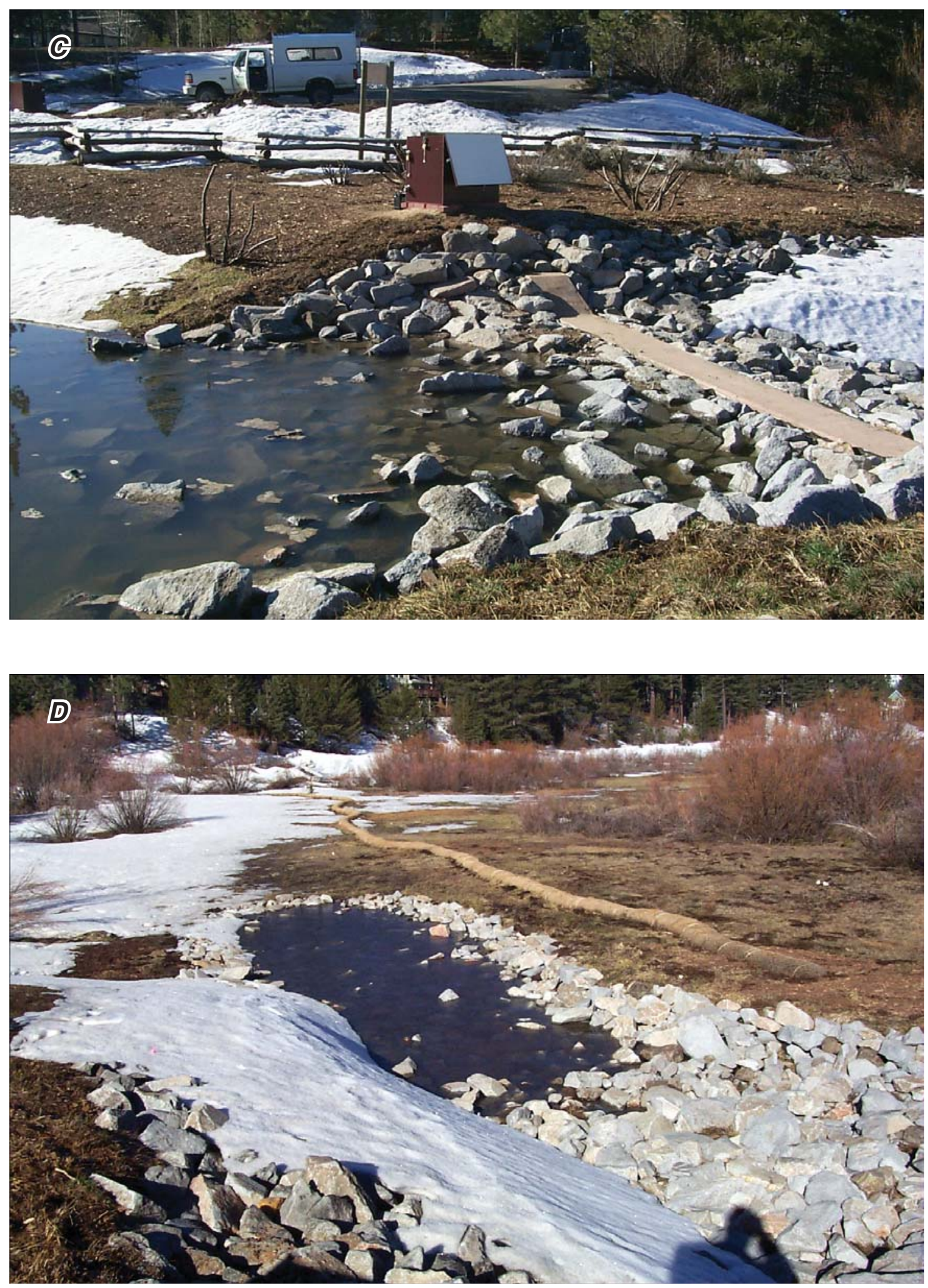

Figure 6.-Continued. 
silicone rubber pump tube. Clear flexible polyvinyl chloride (PVC) tubing ( $3 / 8$ in. inside diameter by $5 / 8$ in. outside diameter) was used for the intake line from the culvert to the sampler. The pump and intake tubing was similar for the ISCO 6700 sampler. The purpose of the flow meters and automatic samplers was to monitor the volume of runoff and the total load of nutrients and sediments that discharge through the culvert. The sampler was set to collect $1.1 \mathrm{qt}$ (1 liter) of water for every $1,500 \mathrm{ft}^{3}$ of flow that passed through the culvert. The initial sampler had 21 bottles and each bottle was 0.8 qt (750 milliliters). Water samples were collected in sequence. The replacement sampler had 8 bottles and each bottle was $2.1 \mathrm{qt}$ ( 2 liters). During runoff, the ISCO 6700 sampler collected a flow portioned sample every 5 minutes whereas the American Sigma collected a 0.21 -qt (200-milliliters) sample for every $300 \mathrm{ft}^{3}$ of flow and thus, the sample interval was dependent on the flow volume. Because nutrient samples are time critical and must be kept chilled, the sampler was routinely checked during and between storms.

\section{Well Location and Construction}

Because of concern over potential transport of nutrients by ground water from the detention basin to Cold Creek, 30 monitoring wells were installed prior to construction (fig. 4). The locations of the wells were selected specifically to help determine directions of ground-water flow in the area of the detention basin and the exchange of ground water with Cold Creek. Wells were placed east and south of the planned detention basin where the land surface altitude was higher, to the north and west between the planned detention basin and Cold Creek, and in the meadow west of the planned spillway structure where the land surface altitude was lower than the basin. In this report, a shallow well adjacent to the deeper well is designated by an $\mathrm{S}$ following the well number and the deeper well is designated by a $\mathrm{D}$ following the well number (for example; wells cc3S and cc3D, table 1).

Wells were installed during November and December 2000. A trailer mounted hollow-stem auger was used to install wells in the area where 4 to $5 \mathrm{ft}$ of fill had been previously placed on top of the meadow. The augered holes measured $7 \mathrm{in}$. in diameter. Well casings made of nominal 2-in. diameter schedule 40 PVC pipe were placed in the augered holes at depths of 9 to $10 \mathrm{ft}$ below land surface (wells cc3S, cc4, cc5, cc6S, cc8S, cc9, cc10, cc13S, and cc15; table 1). These shallow wells were completed in the meadow deposits. Each well casing had a 1-ft long slotted interval (slot size is 0.02 in.) placed $0.5 \mathrm{ft}$ above the bottom of the casing and 2 to $3 \mathrm{ft}$ below the water table at the time the wells were drilled. An end cap was attached to the bottom of each casing using stainless steel rivets. Deeper wells were installed to depths of $15 \mathrm{ft}$ below land surface at selected wells (cc3D, cc6D, cc8D, and cc13D; table 1). The deeper wells were completed in a brown sand and gravel with lenses of silt and sand, and were designed to determine the vertical component of ground-water flow and difference in water chemistry with depth.
Monitoring wells in the meadow and along Cold Creek were installed in hand-augered holes that were 5 to $7.2 \mathrm{ft}$ below land surface (table 1). These hand augered holes were 4.5 in. in diameter. Normally, the nominal 2-in. diameter well casing was installed in the augered holes. Depth to ground water ranged from 2 to $4 \mathrm{ft}$ below land surface at the time the wells were installed. A large stone was encountered while augering the hole for well cc2 (fig. 4) and a 3-in. diameter auger bucket was used until granodiorite was encountered at a depth of $6.8 \mathrm{ft}$. Because of the smaller diameter, a nominal 1-in. diameter schedule 40 PVC well casing was installed in the augered hole (table 1). The well casing had a one-foot slotted interval (slot size is $0.02 \mathrm{in}$.) placed $0.5 \mathrm{ft}$ above the bottom of the casing. The bottom of the casing was capped in the same manner as the 2-in. diameter well casing.

Two deeper wells were drilled adjacent to wells cc17S and cc19S and were designated cc17D and cc19D (table 1). The hole for well cc17D was augered by hand using 4.5 in. diameter bucket and nominal 2-in. diameter well casing was installed to a depth of $10.6 \mathrm{ft}$. However, because of flowing sands encountered while augering the hole for well cc19D, a 3-in. bucket was used inside nominal 4-in. diameter PVC pipe. The pipe was designed to prevent sand from entering the hole. The hole was deepened by alternately pushing the PVC pipe until refusal and then augering out the materials inside the pipe. Total depth of the hole was $10 \mathrm{ft}$. The well was completed in the same manner as well cc2 (table 1).

Wells installed to depths of $10 \mathrm{ft}$ or less were one piece and excess pipe exposed above land surface was cut prior to attaching the upper cap. Wells deeper than $10 \mathrm{ft}$ were installed by attaching a 5-ft section of flush threaded PVC pipe with Teflon O-ring seals to the 10-ft length of PVC pipe with screen. Excess pipe exposed above land surface also was cut prior to attaching the upper cap. Except for the smaller diameter PVC used for wells cc2 and cc19D, the construction of these smaller-diameter wells was the same as the 2-in. well. A lockable and tightly sealed (using two O-rings) cap was placed at the top of each 2-in. diameter PVC pipe to prevent surface runoff from entering the well (fig. 7). The 1-in. diameter wells also were sealed with a lockable cap but the cap differs from the 2-in. diameter wells in that it uses a rubber gasket to seal the top of the casing. Table 1 summarizes the location (latitude and longitude) and construction information for each well.

Once the casing was placed into the hole, the hole around the slotted interval of the well was filled with very coarse silica sand ( 0.04 to 0.08 in.) until the sand was about 0.5 to $1 \mathrm{ft}$ above the screen (fig. 7). A layer (1 to $3 \mathrm{ft}$ thick) of laboratory grade silica flour was placed on top of the very coarse sand. Silica flour was used in place of a bentonite grout because of potential reactions of the sodium-rich bentonite with the ground water. Unconsolidated deposits removed from the hole during augering were placed around the well casing above the silica flour in the deeper holes until the hole was filled to within $3 \mathrm{ft}$ of land surface. Cement grout was poured in the uppermost 1.5 to $3 \mathrm{ft}$ of each hole to seal it. The grout was placed around the 2-in. diameter well cap. Each well cap has a flange at its base (fig. 7) to prevent the cap from being removed once the cement hardened. The top of each well was at or slightly above land surface. 
Table 1. Well name, land-surface altitude, and construction data for wells in the area of Cattlemans detention basin, South Lake Tahoe, California

\begin{tabular}{|c|c|c|c|c|c|c|c|}
\hline \multirow{2}{*}{$\begin{array}{c}\text { Well } \\
\text { name }\end{array}$} & \multirow{2}{*}{$\begin{array}{c}\text { Standard } \\
\text { identification } \\
\text { number }^{1}\end{array}$} & \multirow{2}{*}{$\begin{array}{l}\text { Land-surface } \\
\text { altitude }{ }^{2} \\
\text { (feet) }\end{array}$} & \multirow{2}{*}{$\begin{array}{l}\text { Bottom } \\
\text { of well } \\
\text { (depth, } \\
\text { feet } \\
\text { below } \\
\text { land } \\
\text { surface) }\end{array}$} & \multicolumn{2}{|c|}{$\begin{array}{l}\text { Screened interval } \\
\text { (depth, in feet } \\
\text { below land surface) }\end{array}$} & \multirow{2}{*}{$\begin{array}{l}\text { Wells with } \\
\text { recording } \\
\text { pressure } \\
\text { transducers }\end{array}$} & \multirow{2}{*}{$\begin{array}{l}\text { Lithologic unit in } \\
\text { which screened } \\
\text { interval of well } \\
\text { is completed }\end{array}$} \\
\hline & & & & Top & Bottom & & \\
\hline $\mathrm{cc} 1$ & 385432119574001 & $6,278.84$ & 5.6 & 4.1 & 5.1 & no & meadow deposits \\
\hline $\operatorname{cc} 2$ & 385432119574002 & $6,281.57$ & 6.8 & 5.3 & 6.3 & no & weathered granodiorite \\
\hline $\operatorname{cc} 3 S$ & 385432119574301 & $6,281.23$ & 10.2 & 8.7 & 9.7 & yes & meadow deposits \\
\hline $\operatorname{cc} 3 \mathrm{D}$ & 385432119574302 & $6,281.21$ & 15.1 & 13.6 & 14.6 & yes & sand and gravel \\
\hline $\operatorname{cc} 4$ & 385433119574201 & $6,279.12$ & 10.2 & 8.7 & 9.7 & no & meadow deposits \\
\hline $\operatorname{cc} 5$ & 385433119574202 & $6,278.03$ & 10.2 & 8.7 & 9.7 & no & meadow deposits \\
\hline $\operatorname{cc} 6 \mathrm{~S}$ & 385433119574301 & $6,277.37$ & 9.0 & 7.5 & 8.5 & yes $^{5}$ & meadow deposits \\
\hline $\operatorname{cc} 6 \mathrm{D}$ & 385433119574302 & $6,277.40$ & 15.0 & 13.5 & 14.5 & yes $^{5}$ & sand and gravel \\
\hline $\operatorname{cc} 7$ & 385433119574203 & $6,273.29$ & 5.0 & 3.5 & 4.5 & no & meadow deposits \\
\hline $\operatorname{cc} 8 \mathrm{~S}$ & 385432119574303 & $6,278.13^{4}$ & 9.2 & 7.7 & 8.7 & yes $^{5}$ & meadow deposits \\
\hline $\operatorname{cc} 8 \mathrm{D}$ & 385432119574304 & $6,278.15^{4}$ & 15.0 & 13.5 & 14.5 & yes $^{5}$ & sand and gravel \\
\hline $\operatorname{cc} 9$ & 385432119574305 & $6,279.30$ & 9.9 & 8.4 & 9.4 & no & meadow deposits \\
\hline $\operatorname{cc} 10$ & 385433119574303 & $6,276.39$ & 10.2 & 8.7 & 9.7 & no & meadow deposits \\
\hline $\operatorname{cc} 11$ & 385434119574401 & $6,272.83$ & 5.7 & 4.2 & 5.2 & no & meadow deposits \\
\hline $\operatorname{cc} 12$ & 385434119574402 & $6,272.64$ & 5.1 & 3.6 & 4.6 & no & meadow deposits \\
\hline $\operatorname{cc} 13 \mathrm{~S}$ & 385433119574401 & $6,275.14$ & 10.2 & 8.7 & 9.7 & yes & meadow deposits \\
\hline $\mathrm{cc} 13 \mathrm{D}$ & 385433119574402 & $6,275.69$ & 15.2 & 13.7 & 14.7 & yes & sand and gravel \\
\hline cc14 & 385433119574403 & $6,272.60$ & 5.5 & 4.0 & 5.0 & yes & meadow deposits \\
\hline $\operatorname{cc} 15$ & 385432119574401 & $6,278.33$ & 10.2 & 8.7 & 9.7 & no & meadow deposits \\
\hline $\operatorname{cc} 16$ & 385433119574404 & $6,273.47$ & 7.2 & 5.7 & 6.7 & no & meadow deposits \\
\hline $\operatorname{cc} 17 \mathrm{~S}$ & 385433119574501 & $6,272.71$ & 6.7 & 5.2 & 6.2 & no & meadow deposits \\
\hline cc17D & 385433119574502 & $6,272.82$ & 10.6 & 9.1 & 10.1 & no & sand and gravel \\
\hline $\operatorname{cc} 18$ & 385433119574503 & $6,271.93$ & 5.1 & 3.6 & 4.6 & no & meadow deposits \\
\hline $\operatorname{cc} 19 \mathrm{~S}$ & 385433119574504 & $6,272.19$ & 5.6 & 4.1 & 5.1 & no & meadow deposits \\
\hline cc19D & 385433119574505 & $6,272.11$ & 10.0 & 8.5 & 9.5 & no & sand and gravel \\
\hline $\operatorname{cc} 20$ & 385432119574501 & $6,272.77$ & 7.2 & 5.7 & 6.7 & no & meadow deposits \\
\hline $\operatorname{cc} 21$ & 385432119574601 & $6,272.19$ & 5.0 & 3.5 & 4.5 & no & meadow deposits \\
\hline $\operatorname{cc} 22$ & 385433119574701 & $6,271.94$ & 5.6 & 4.1 & 5.1 & no & meadow deposits \\
\hline $\operatorname{cc} 23$ & 385433119574702 & $6,271.08$ & 5.4 & 3.9 & 4.9 & no & meadow deposits \\
\hline $\operatorname{cc} 24$ & 385432119574701 & $6,271.97$ & 5.5 & 4.0 & 5.0 & no & meadow deposits \\
\hline
\end{tabular}

${ }^{1}$ Standard identification number is used to store all ground water information in the National Water Information System (NWIS). The first 6 digits are the latitude of the well in degrees, minutes, and seconds; the following 7 digits are the longitude of the well in degrees, minutes, and seconds; and the last 2 digits are for sequential numbering of wells when more than one well has the same latitude and longitude. Location of wells is shown in figure 4.

${ }^{2}$ Land-surface altitude referenced to pin set by Tahoe Engineering Division of the El Dorado County Department of Transportation at end of Cattlemans Court. Altitude referenced to NGVD of 1929.

${ }^{3}$ Meadow deposits consist of gray silt and sand with stringers of coarse sand and fine gravel. The deeper sand and gravel consists of brown to yellow-brown sand and gravel with lenses of silt and sand. Both units are alluvium deposited by Cold Creek.

${ }^{4}$ Surface casing lowered at wells cc8S and cc8D October 3, 2001 after construction of detention basin. Excavation lowered land surface to $6,276.63$ feet at well cc8S and to $6,276.95$ feet at well cc8D. Total depth of well $8 \mathrm{~S}$ was decreased to 7.7 feet and well cc8D was decreased to 13.8 feet.

${ }^{5}$ Recording pressure transducers initially in wells cc $8 \mathrm{~S}$ and cc8D were moved to wells cc $6 \mathrm{~S}$ and cc $6 \mathrm{D}$ following construction of detention basin in October 2001 because of concerns that the pond behind the detention dam could flood wells cc8S and cc8D. 


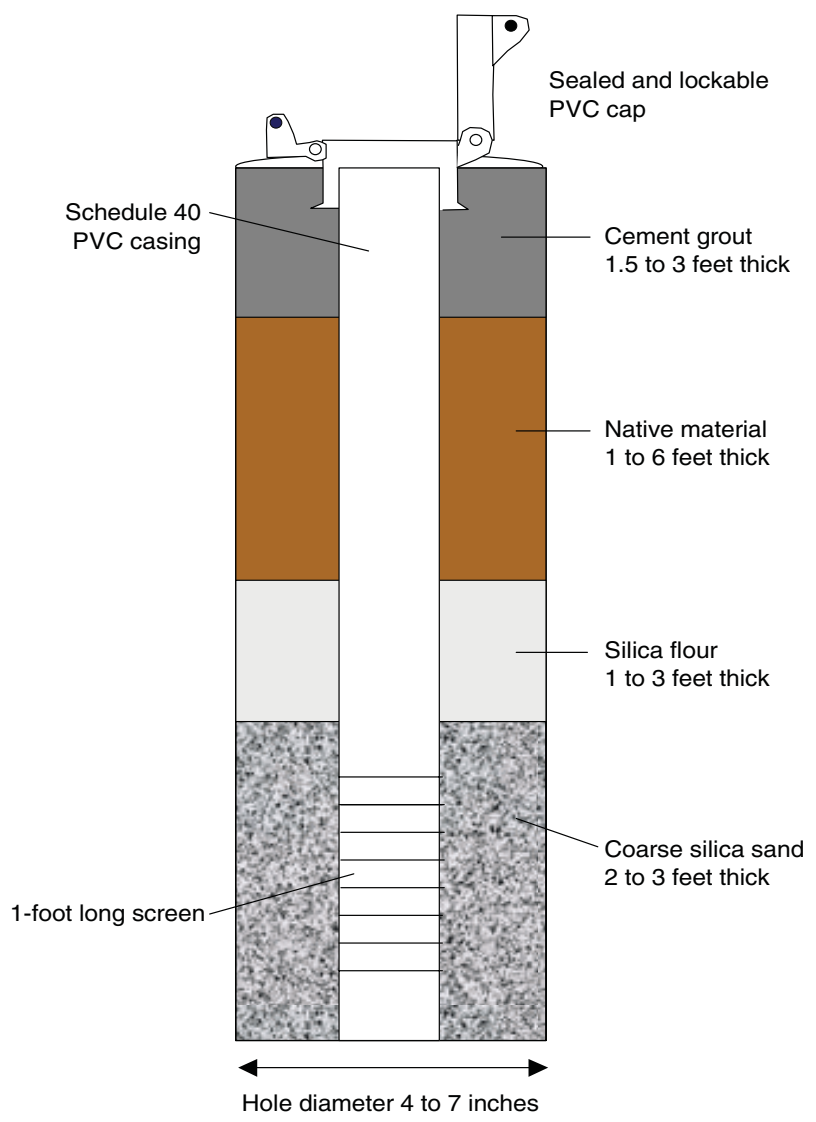

Figure 7. Diagram showing construction of wells in the area of Cattlemans detention basin.

\section{Measurement of Water Levels in Wells and Stage of Cold Creek}

Measurements of depth to water in the wells were made periodically. Depth to water was measured using either a steel tape or an electric tape calibrated to a steel tape. Water depths ranged from $2 \mathrm{ft}$ or less below land surface in wells located next to Cold Creek to more than $9 \mathrm{ft}$ below land surface at wells cc $3 \mathrm{~S}$ and cc3D. Water-level altitudes were determined by subtracting the depth to water in each well from the altitude of the top of each well. The altitude of the top of each well was surveyed using a Nikon Total Station (model DTM-A5LG) and an altitude reference mark set by the TED at the north end of Cattlemans Court. The reference mark has an altitude of 6,282.85 ft above sea level.

Several monitoring wells (cc3S, cc8S, cc8D, cc13S, cc13D, and cc14) were installed with Global Water pressure transducers (Global Water, Inc. model number WL14x) during January 2000 to record changes in water levels during the inaccessible period, when snow covered the ground, and to assess daily variations in water levels. Each pressure transducer and attached datalogger fits inside the 2-in. diameter PVC casing and has a range from 0 to $15 \mathrm{ft}$. Additional pressure transducers were installed in June 2001 at well cc3D and in Cold Creek next to well cc14. One pressure transducer failed shortly after it was installed in January 2001 and reliable data were not obtained until June 2001. Water-level data from the pressure transducers were recorded every hour and the data were retrieved from the dataloggers using a laptop computer.

\section{Water Quality Sampling Procedures}

\section{Urban Runoff}

Samples of urban runoff collected by the automatic samplers were frozen and then sent to a laboratory for nutrient and total suspended-solid analyses. The water was unfiltered and only total concentrations of nutrients were determined. Initially (April and May 2000), most samples were analyzed for total suspended solids and selected samples also were analyzed for nutrient content. Nutrient analyses of the unfiltered water consisted of ammonia (or ammonium), nitrate plus nitrite, total Kjeldahl nitrogen (ammonia plus organic nitrogen), soluble reactive phosphorus (orthophosphorus), total phosphorus, and total iron (analyzed starting October 26, 2000). Because of difficulties in estimating the total mass of nutrients from analyses of selected samples for each runoff period in April and May 2000, a composite of the individual samples for each 
subsequent runoff period was done by shaking each sample and mixing a known volume from each that was representative of the percentage of the total runoff. The composite, which was representative of total runoff, was then analyzed for nutrients.

\section{Ground Water and Cold Creek}

Wells selected for chemical and nutrient analyses were pumped using a portable battery-operated peristaltic pump using C-flex (Masterflex 6424-15) tubing. The C-flex tubing was rinsed with deionized water following each sampling. About $1 \mathrm{gal}$ was pumped from the wells every $10 \mathrm{~min}$. At least three well-bore volumes were pumped prior to sampling. Volumes ranged from about $1 \mathrm{qt}$ (for the shallow wells in the meadow area) to $2 \mathrm{gal}$ (for the deeper wells). Two wells (wells cc17S and cc21) recovered slowly after water was removed from the casing. These wells were allowed to recover before removing more water from the casing. The process was repeated until three well-bore volumes were removed.

Measurements of temperature, specific conductance, and $\mathrm{pH}$ were made in a flow-through cell at the time the wells were sampled. Alkalinity and dissolved oxygen also were determined at the time of sampling for wells that were sampled for major and trace inorganic dissolved constituents. Bicarbonate concentrations were calculated from alkalinity. Initially, eight wells were sampled for dissolved nutrients, organic carbon, and major and trace inorganic constituents in January 2001. During the spring, summer, and fall of 2001, all wells were sampled for nutrients at least once and 26 wells were sampled three times. During this same period, 13 wells were sampled three times for dissolved organic carbon and major and trace inorganic constituents. All ground water samples were filtered through a 0.45 -micron filter.

Water samples were collected in September 2001, from Cold Creek adjacent to well cc1 above Pioneer Trail and well cc14 below the detention basin. Samples were collected by placing the end of the $\mathrm{C}$-flex tubing from the peristaltic pump at mid-depth in the creek and pumping water through a flowthrough chamber prior to collecting the sample. The purpose of these samples was to compare the chemical quality of water in the creek with that of ground water in the wells next to the creek above and below the planned detention basin. Measurements of temperature, specific conductance, $\mathrm{pH}$, and dissolved oxygen were made in the flow-through chamber at the time of sampling. The water samples from Cold Creek were filtered.

Water samples collected for nutrient analyses were split into 3 bottles. The nutrient analyses included Kjedahl nitrogen, ammonia, nitrate plus nitrite, phosphorus, orthophosphorus, and iron. The water sample for filtered iron was acidified with nitric acid to a pH of 2.0 or less. The water samples were placed on ice and chilled to $4^{\circ} \mathrm{C}$ or less and remained chilled until analyzed. Water samples collected for dissolved organic carbon were poured into an amber colored glass bottle and preserved with $4.5 \mathrm{~N}$ sulfuric acid. Water samples collected for anions were poured into a bottle untreated and the samples that were used for cations and trace elements were poured into a separate bottle and acidified with nitric acid to a pH of 2.0 or less. One unfiltered and untreated water sample was used for laboratory determination of specific conductance and $\mathrm{pH}$.

\section{Analyses of Water Quality}

Water samples from urban runoff collected by TED were sent to Acculabs, Inc. in Sparks, Nevada, which is an Environmental Protection Agency (EPA) certified laboratory. All other water samples collected by the USGS were sent either to the USGS National Water Quality Laboratory (NWQL) in Lakewood, Colorado (major and trace inorganic constituents and dissolved organic carbon) or to the University of California, Davis, Tahoe Research Group (TRG) Laboratories (nutrients and filtered iron). Samples for kjeldahl nitrogen (ammonia and organic nitrogen) and (filtered and biologically available) iron were sent to the University of California, Davis in Davis, California and the other samples were sent to the TRG Laboratory in Tahoe City, California. Analytical results from all ground water and Cold Creek samples are stored in the USGS National Water Information System (NWIS) data base. Analytical results from urban runoff are available from TED.

\section{Urban Runoff}

Nutrient concentrations in runoff were determined for six runoff events that occurred between August 2000 and March 2001 (table 2). The largest event with the greatest loads occurred on August 3, 2000 when a thunder storm resulted in runoff through the culvert of about $30,000 \mathrm{ft}^{3}$ over a 5 -hour period. The estimated total load of nitrogen was $190 \mathrm{oz}(5,300$ grams) of which most was in the form of organic nitrogen and the total load of phosphorus was $8.1 \mathrm{oz}$ (230 grams; table 2). Total suspended solids were estimated at 4,000 lbs. The mean concentration of total nitrogen was $6.4 \mathrm{mg} / \mathrm{L}$ and total phosphorus was $0.28 \mathrm{mg} / \mathrm{L}$.

The highest runoff rate (total runoff divided by duration) occurred on September 1, 2000 when 19,000 $\mathrm{ft}^{3}$ was estimated during a 11/2-hr period (table 2). Although the runoff rate was more than that of the August storm, the total load of nitrogen was only $17 \mathrm{oz}$ (480 grams), phosphorus was $3.9 \mathrm{oz}$ (110 grams), and total suspended solids were only $55 \mathrm{lbs}$. The mean concentration of total nitrogen was $0.9 \mathrm{mg} / \mathrm{L}$ and total phosphorus was $0.2 \mathrm{mg} / \mathrm{L}$. The considerably lower loads may have resulted because much of the nutrients and sediments had been removed from the drainage area during the August event and insufficient time had elapsed to accumulate more. Three urban runoff events were recorded in October 2000. Total nitrogen and phosphorus loads in the three October events were similar to the September event; however, total suspended solids in all three October events were about three times greater than the September event. 
Table 2. Duration, total volume, nutrient mass, and total suspended solids of urban runoff from Pioneer Trail and Montgomery Estates subdivision, August 2000 to March $2001^{1}$

[Symbols: <, less than; --, no data]

\begin{tabular}{|c|c|c|c|c|c|c|c|c|c|c|c|}
\hline \multirow[t]{2}{*}{ Date } & \multirow[t]{2}{*}{$\begin{array}{l}\text { Duration } \\
\text { (hours) }\end{array}$} & \multirow[t]{2}{*}{$\begin{array}{c}\text { Total } \\
\text { volume } \\
\text { (cubic feet) }\end{array}$} & Ammonia & Nitrate & Nitrite & $\begin{array}{c}\text { Ammonia } \\
+ \text { organic } \\
\text { nitrogen }\end{array}$ & $\begin{array}{c}\text { Total } \\
\text { nitrogen }\end{array}$ & $\begin{array}{c}\text { Soluble } \\
\text { reactive } \\
\text { (ortho) } \\
\text { phosphorus }\end{array}$ & $\begin{array}{c}\text { Total } \\
\text { phosphorus }\end{array}$ & $\begin{array}{l}\text { Total } \\
\text { iron }\end{array}$ & $\begin{array}{c}\text { Total } \\
\text { suspended } \\
\text { solids }\end{array}$ \\
\hline & & & \multicolumn{5}{|c|}{ Ounces of nitrogen } & \multicolumn{2}{|c|}{ Ounces of phosphorus } & \multicolumn{2}{|c|}{ Pounds } \\
\hline $08 / 03 / 2000$ & 5 & 30,000 & 5.6 & 1.4 & $<0.28$ & 190 & 190 & 0.56 & 8.1 & -- & 4,000 \\
\hline $09 / 01 / 2000$ & 1.5 & 19,000 & 1.1 & 2.8 & .19 & 14 & 17 & 1.5 & 3.9 & -- & 55 \\
\hline $10 / 09 / 2000$ & 2 & 2,600 & .71 & $<.14$ & $<.03$ & 21 & 21 & $<.07$ & 2.2 & -- & 157 \\
\hline $10 / 26 / 2000$ & 22 & 25,000 & $<1.2$ & $<.25$ & $<.25$ & 28 & 28 & 1.5 & 4.6 & 6.0 & 163 \\
\hline $10 / 28 / 2000$ & 21 & 17,000 & $<.85$ & $<.18$ & $<.18$ & 14 & 14 & .85 & 2.5 & 5.3 & 165 \\
\hline $03 / 06 / 2001$ & 13 & 26,000 & 3.1 & 4.9 & $<.28$ & 39 & 44 & .74 & 6.7 & 11 & 287 \\
\hline
\end{tabular}

\footnotetext{
${ }^{1}$ Data are from the Tahoe Engineering Division of the El Dorado County Department of Transportation, South Lake Tahoe, California. Nutrient and total suspended solids were analyzed by Acculabs, Inc. in Sparks, Nevada, for El Dorado County Department of Transportation. Acculabs is an U.S. Environmental Protection Agency (EPA) certified laboratory. Data used for this table are available through El Dorado County Department of Transportation. Sampling location is shown in figure 5.
}

Only one urban runoff event was recorded during snowmelt in the spring of 2001. Total runoff for the March 6, 2001, event was 26,000 $\mathrm{ft}^{3}$ and was nearly equal to that on August 3, 2000 , although the duration was 2.5 times longer; however, the total nitrogen load for this event was considerably less than that for the August 2000 event (table 2). The dominant form of nitrogen for the March 6, 2001 event was still organic nitrogen even though nitrate (plus nitrite) load was the highest of any recorded event. The mean total nitrogen concentration during the March 6, 2001 event was $1.7 \mathrm{mg} / \mathrm{L}$, and total phosphorus was $0.26 \mathrm{mg} / \mathrm{L}$.

\section{Ground Water}

The shallow ground-water system beneath Cattlemans detention basin is a potential pathway for dissolved nutrients in urban runoff to reach Cold Creek. Ground water has the potential to flow from the detention basin through unconsolidated deposits and discharge into Cold Creek. Understanding groundwater flow is important in assessing how effectively the detention basin reduces nutrients loads to Cold Creek.

Ground water in the area of the detention basin prior to its construction primarily was from four sources: recharge from precipitation and snowmelt; subsurface flow from the adjacent upland areas; seepage from Cold Creek into unconsolidated deposits upstream of Pioneer Trail; and periodic infiltration of urban runoff.

\section{Distribution of Unconsolidated Deposits}

Unconsolidated deposits penetrated during the augering for each monitoring well were classified according to texture, color, and odor. Three general classes of unconsolidated deposits were categorized—fill, organic silt and sand, and sand and gravel (fig. 8). Fill material consists of red-brown loamy sand with some gravel and an occasional cobble. The loamy sand is similar to that found in the adjacent uplands and the gravel and cobbles are granodiorite. This suggests the fill was obtained locally and placed on top of the meadow. Construction materials such as wood and electrical wiring were occasionally encountered in the fill.

Immediately below the fill are meadow deposits that consist of medium to dark gray organic silt and sand with stringers of coarse sand and fine gravel. These deposits contain organic matter, have a musty odor, and are generally from 5 to $8 \mathrm{ft}$ thick in the area of the detention basin. Mica flecks are common throughout the deposits. Roots from the meadow grasses are common to a depth of $1 \mathrm{ft}$ and occasional pieces of decomposing wood (possibly roots of large trees) were found in the deposits.

The origin of meadow deposits might be related to a change in the slope of the Cold Creek channel. Upstream (east) of Pioneer Trail, Cold Creek is incised into bedrock and has a higher gradient than the channel downstream (west) of Pioneer Trail (Harrill, 1977). The deposit could be from the gradual accumulation of sediments during flooding that caused Cold Creek to overflow its banks and spread across the meadow. Another possibility is that the lenses of silt were deposited in shallow ponds that may have formed in the meadow.

The third category of deposits found in the augered holes is a sand and gravel with lenses of silt and sand. The thickness of this unit is unknown but it was found everywhere beneath the gray organic silt and sand. The unconsolidated deposits consist of a brown to yellow brown (oxidized) sand and gravel with lenses of silt and sand. The deposits are similar in origin to the meadow deposits. A profile across the detention basin prior to construction (fig. 8) shows the general distribution of unconsolidated deposits. 


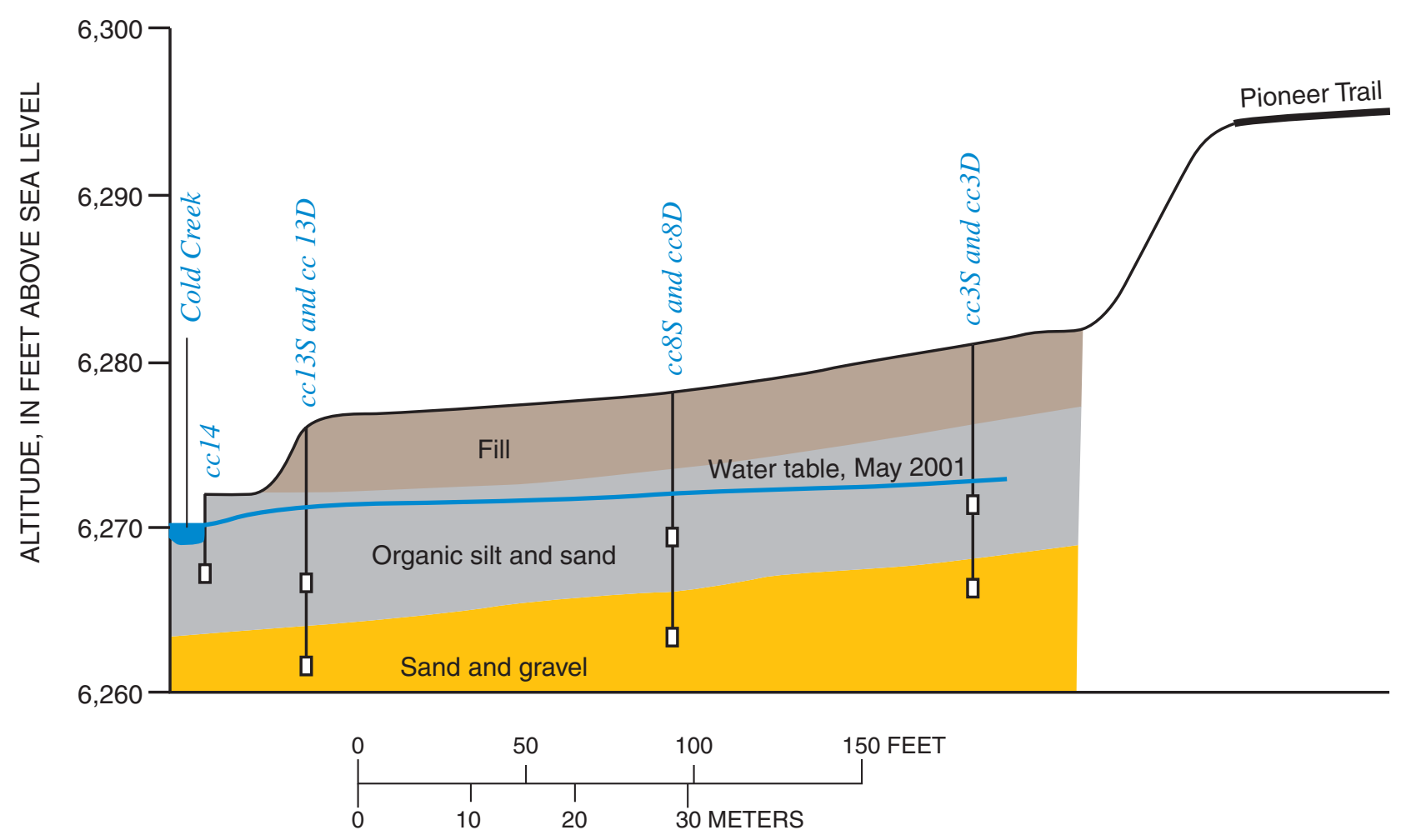

Figure 8. Distribution of shallow unconsolidated deposits beneath Cattlemans detention basin prior to its construction.

Depth to bedrock along a north-south profile just west of the planned detention basin was estimated from seismicrefraction data (location of north-south profile is shown on fig. 2). The following discussion is excerpted from D.L. Berger (U.S. Geological Survey, written commun., 2004). The seismicrefraction data is based on measured travel times of artificially generated waves of elastic energy. The waves of elastic energy refract according to Snell's Law whenever they encounter a contrast in properties within the subsurface, such as a contrast between unconsolidated deposits and bedrock (Telford and others, 1976, p. 245). For the method to work, each successively deeper refractor must have a higher seismic velocity along with a considerable velocity contrast.

Travel times of the refracted elastic energy waves are measured by an array of geophones. The travel times are plotted against distance from the surface shock point along the line (profile) of geophones (for example, see fig. 9A). The inverse slope of the time-distance curve is equal to the apparent velocity of a corresponding refracting interface in the subsurface. Travel-time estimates are collected from the surface shock points at either end of the seismic profile to correct for dipping interfaces and to compute a true seismic velocity. The seismic profile was $473 \mathrm{ft}$ long and consisted of two seismic lines of 12 geophones spaced $20 \mathrm{ft}$ apart. Because of the shallow depth to saturated deposits (water table was less than $3 \mathrm{ft}$ below land surface in September 2001) relative to the spacing of the geophones (20-ft spacing), an accurate estimate of the depth to saturated deposits along the transect could not be made. The velocity of the unsaturated deposits ranged from 1,700 to $3,100 \mathrm{ft} / \mathrm{s}$ (fig. $9 A$ ) and averaged 2,300 ft/s. The velocity of the saturated deposits ranged from 4,800 to $5,800 \mathrm{ft} / \mathrm{s}$ (fig. $9 A$ ) and averaged 5,500 ft/s. The velocity of the buried granitic bedrock (granodiorite) ranged from 10,700 to 14,700 ft/s (fig. 9A) and averaged $12,700 \mathrm{ft} / \mathrm{s}$.

The seismic-refraction data were interpreted by an inversion algorithm that used the delay-time method (Barthelmes, 1946; Pakiser and Black, 1957) to obtain a first-approximation depth model, then these approximations were enhanced by a series of ray-tracing iterations (Scott, 1993). The result is the estimated profile of the contact between the unconsolidated deposits and the buried granitic bedrock (fig. 9B). The estimated altitude of the bedrock just west of the planned detention basin was about $6,200 \mathrm{ft}$ (south end of profile), which means that the thickness of unconsolidated deposits is about $80 \mathrm{ft}$. The bedrock surface rises to the north where the altitude of the bedrock is about $6,220 \mathrm{ft}$ and there, the depth to bedrock is about $60 \mathrm{ft}$. 

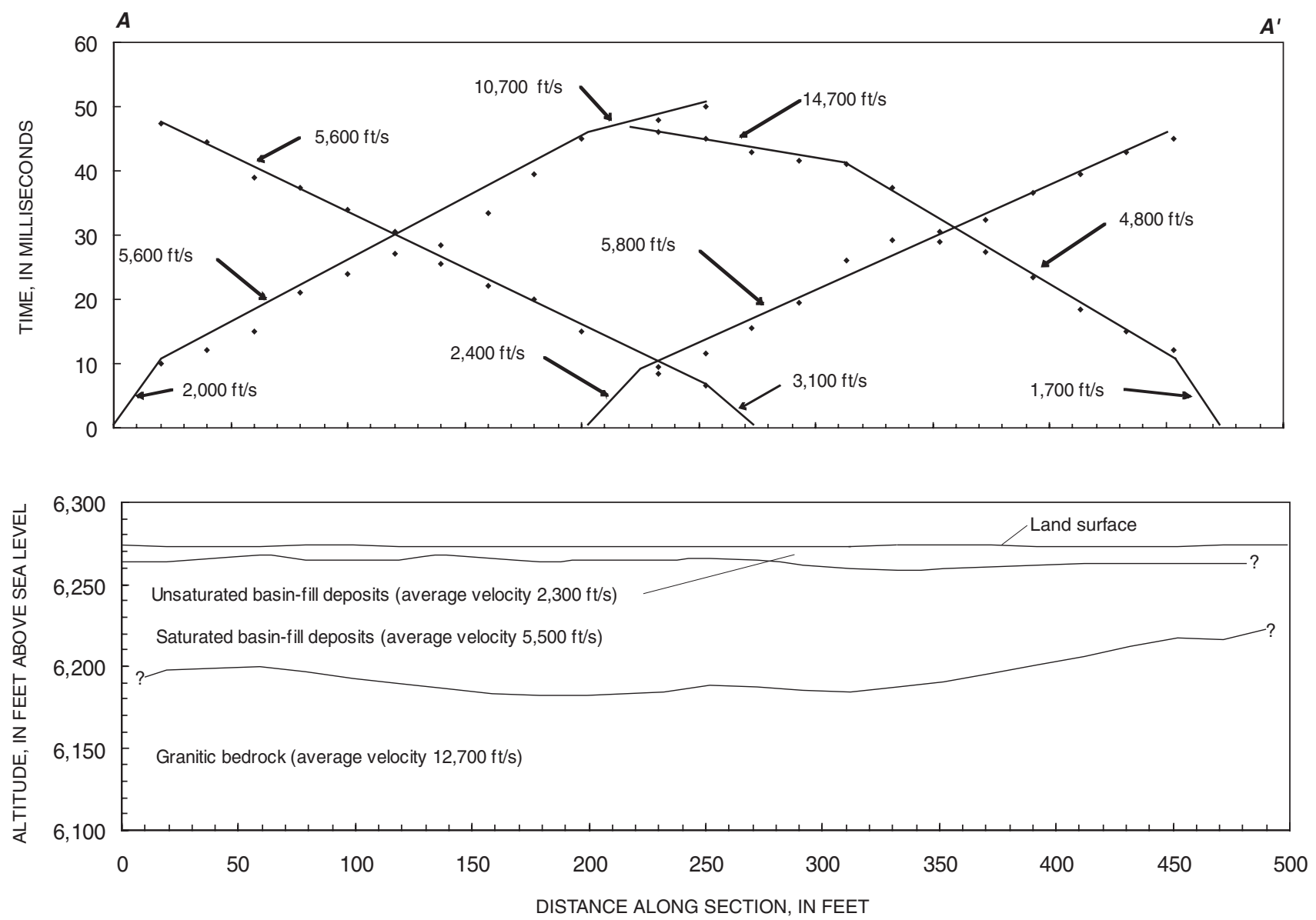

Figure 9. Time-distance curves and velocity-depth profile for seismic-refraction line $A-A$ 'near Cattlemans detention basin. Location of line is shown on figure 2. Units are in feet per second (ft/s).

The depth to bedrock decreases eastward because granodiorite is exposed at the surface east of Pioneer Trail and the area is mapped as bedrock (fig. 1). Bedrock (granodiorite) may have been encountered in well cc2 at a depth of $6.8 \mathrm{ft}$ below land surface. This well is east of Pioneer Trail and near the base of the hill slope (fig. 4).

\section{Direction of Ground-Water Flow}

Ground-water flow generally is from areas of higher ground-water levels to areas of lower ground-water levels. Prior to construction of the detention basin, the ground-water levels were highest east of Pioneer Trail and decreased westward following the slope of the meadow (fig. 10). On the basis of ground-water level contours, ground water beneath the planned detention basin was flowing toward two meanders on Cold Creek that trend perpendicular to the direction of groundwater flow. Although ground-water levels were higher in the spring and lower in the fall and winter, the general pattern of higher ground-water levels east of Pioneer Trail and lower ground-water levels west of the planned detention basin remained persistent throughout the year indicating the direction of flow also did not change.

\section{Seasonal Trends in Ground-Water Levels}

Ground-water levels increased rapidly at wells cc3S and cc13S beginning March 5, 2001 (fig. 11). The response at wells cc8S and cc8D were much less on March 5 in relation to the rapid increase on March 16, 2001. The rapid rise on March 5, 2001, correlates to precipitation that likely was in the form of rain (fig. $11 C$; minimum temperature was near freezing and maximum temperature was above freezing). The absence of a water-level rise in February was because much of the precipitation was in the form of snow (fig. $11 C$; precipitation occurred on days when temperatures were generally below freezing). The delayed response at wells cc8S and cc8D could have been due to the wells being in the center of the area covered by fill.

Water levels in wells with recording pressure transducers peaked on March 21, 2001, declined through early April, and then increased again following snowstorms on April 6 and 7 (figs. 11C). Water levels reached a second peak on April 23, 2001, that followed 4 days of rain and snow from April 18-21, 2001 (fig. 11C) before slowly declining until September 2001. The increase in water levels at the end of August 2001 was not related to precipitation; however, the rapid increase on September 25, 2001, corresponds to rain on the same day. 


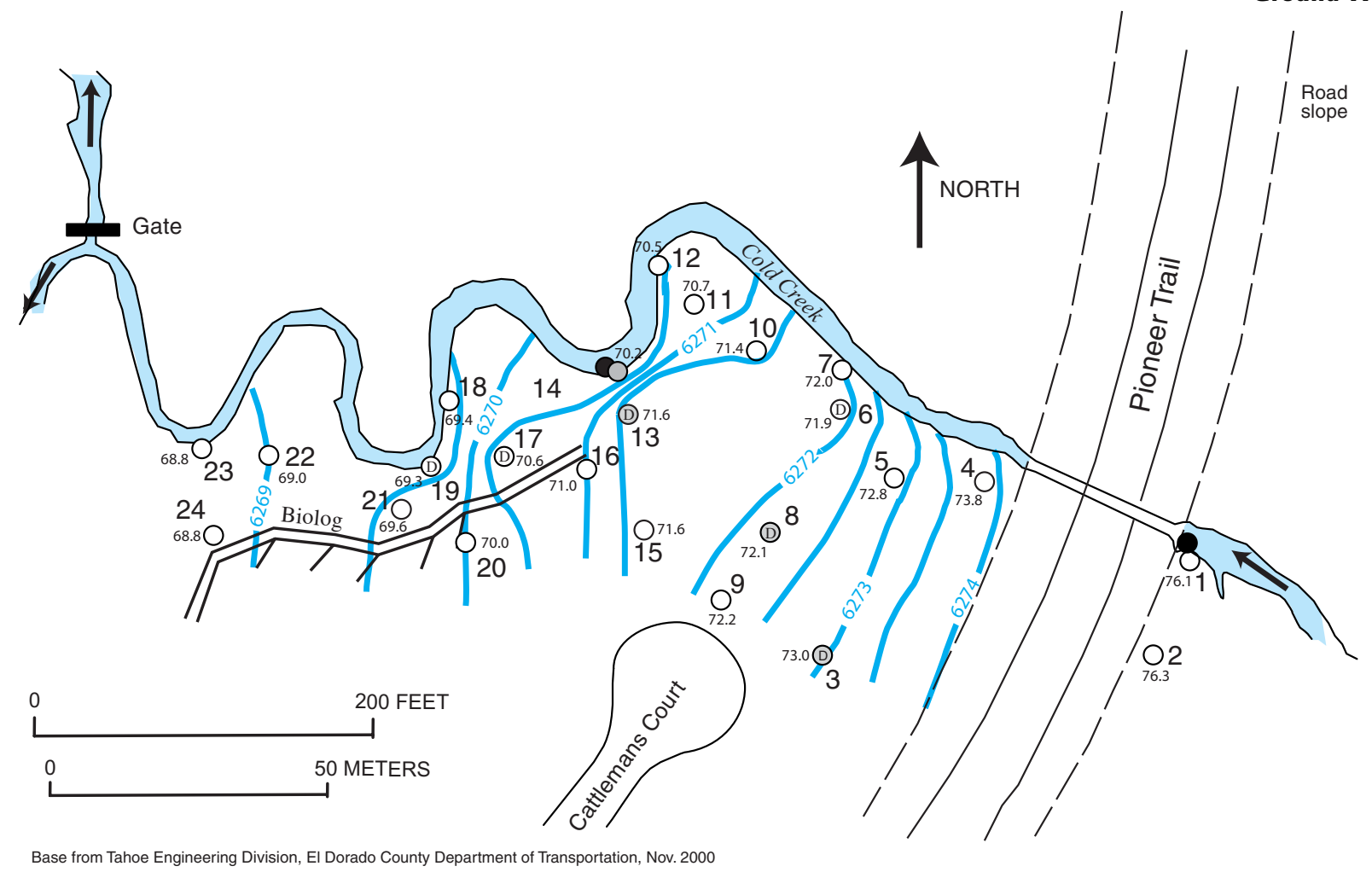

Base from Tahoe Engineering Division, El Dorado County Department of Transportation, Nov. 2000

\section{EXPLANATION}

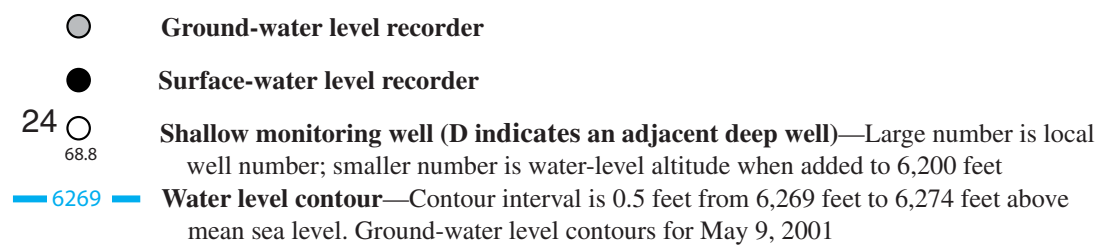

Figure 10. Ground-water level contours for May 2001 in the area of Cattlemans detention basin prior to its construction. Well name listed in table 1 has been abbreviated by omitting the "cc" designation.

The greatest rise in water level was observed at well cc3S, which rose $2.3 \mathrm{ft}$ between January 30 and March 21, whereas the water level rose only $0.2 \mathrm{ft}$ during the same period at well cc14 next to Cold Creek. The observed trends in water levels in the area of the detention basin prior to its construction are consistent with subsurface flow from the upland areas to the east and south, and recharge from infiltration of precipitation (rain and snowmelt) and urban runoff in the study area. The groundwater levels rose throughout the study area between January and May 2001 as indicated from periodic measurements in all the wells and declined during the summer (fig. 12). Again, the trends are consistent with recharge during the spring, and discharge of ground water to Cold Creek as well as discharge by evapotranspiration in the meadow during the summer.

Differences in ground-water levels between the paired shallow and deep wells (figs. 11 and 12) indicate that ground water was moving upward from the deeper sand and gravel into the meadow deposits at the middle part of the detention basin prior to construction (wells cc8S, and cc8D; fig. 11A). The ground-water level in wells cc3D and cc6D also were slightly higher than the ground-water levels in wells cc $3 \mathrm{~S}$ and cc6S, although differences were slight. In contrast, a component of water in the meadow deposits was contributing water to the deeper deposits at the lower end (wells cc13S and cc13D in fig. $11 B$ ). The change from an upward gradient at well cc8S to a downward gradient at well cc13S suggests the unconsolidated deposits thicken rapidly between the two wells.

The stage of Cold Creek next to well cc14 was monitored with a pressure transducer beginning June 13, 2001. The rapid response between stage and ground-water levels in well cc14 indicates that the shallow ground water and the creek are hydraulically connected (fig. 13). The stage was slightly less than that in well cc14 with the greatest difference in June. Water levels slowly converged until August when they were nearly the same (within $0.02 \mathrm{ft}$ ). Plywood was placed across the culvert on the upstream side of Pioneer Trail by neighborhood youths to create a pond. This decreased the stage of Cold Creek downstream of the culvert and in well cc14 and increased water levels in wells cc1, cc2, and cc4 (well cc5 showed only a slight rise) in August 2001 (fig. 12). The observed rise in these wells while Cold Creek was dammed at the culvert indicates that groundwater levels beneath the detention basin are sensitive to changes in water levels in Cold Creek above Pioneer Trail. The plywood was removed on September 25; the same day that 0.3 in. of precipitation was recorded at a nearby weather station (fig. 11C). 

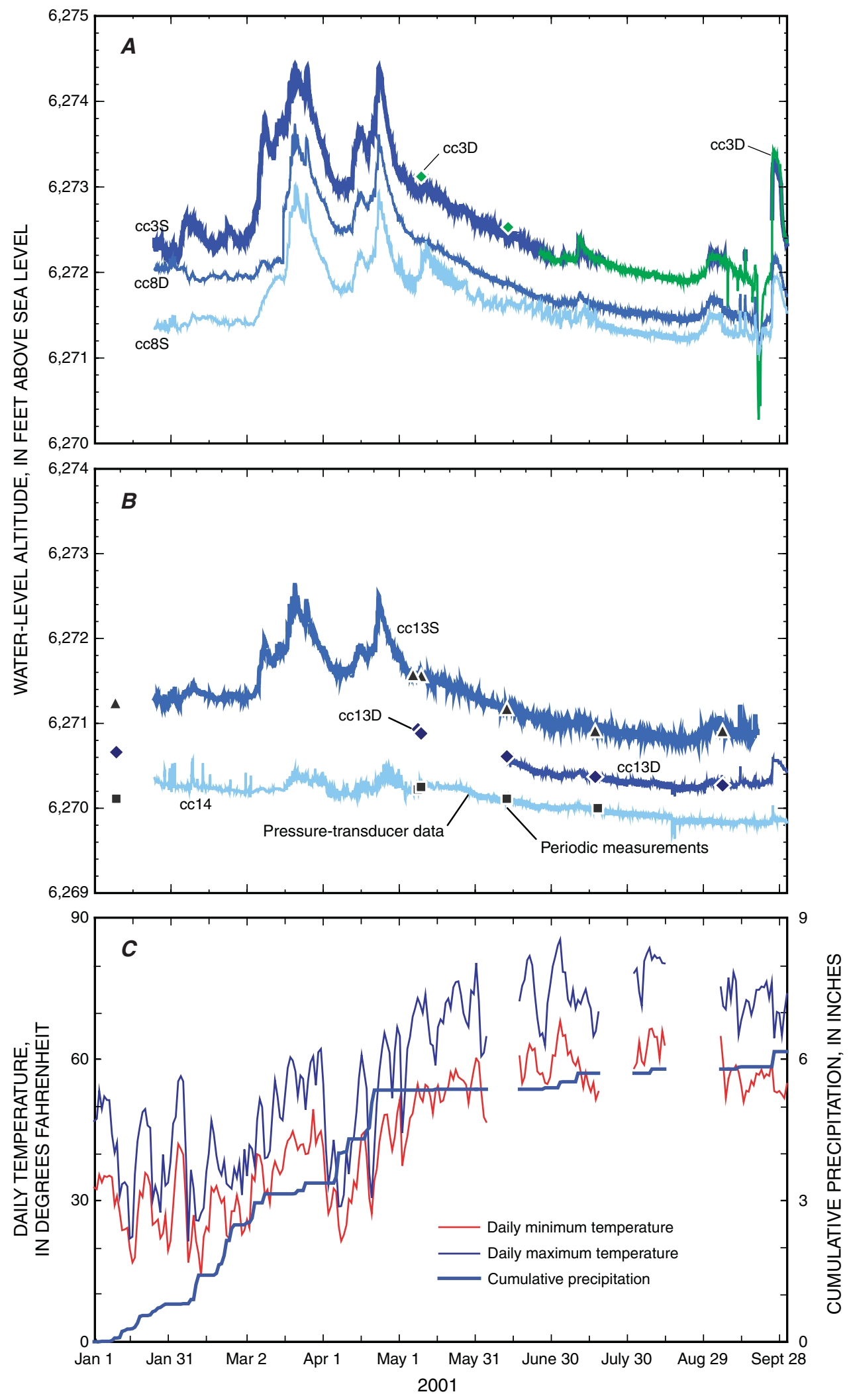

Figure 11. Trends of ground-water levels in wells with recording pressure transducers in the area of Cattlemans detention basin prior to and during its construction in relation to precipitation and air temperature, January through September 2001: $(A)$ wells cc3S, cc3D, cc8S, cc8D; $(B)$ wells cc13S, cc13D, and cc14; and $(C)$ cumulative precipitation and daily minimum and maximum temperature from weather station at the nearby elementary school. Location of wells is shown in figure 4, and location of weather station is shown in figure 5. 

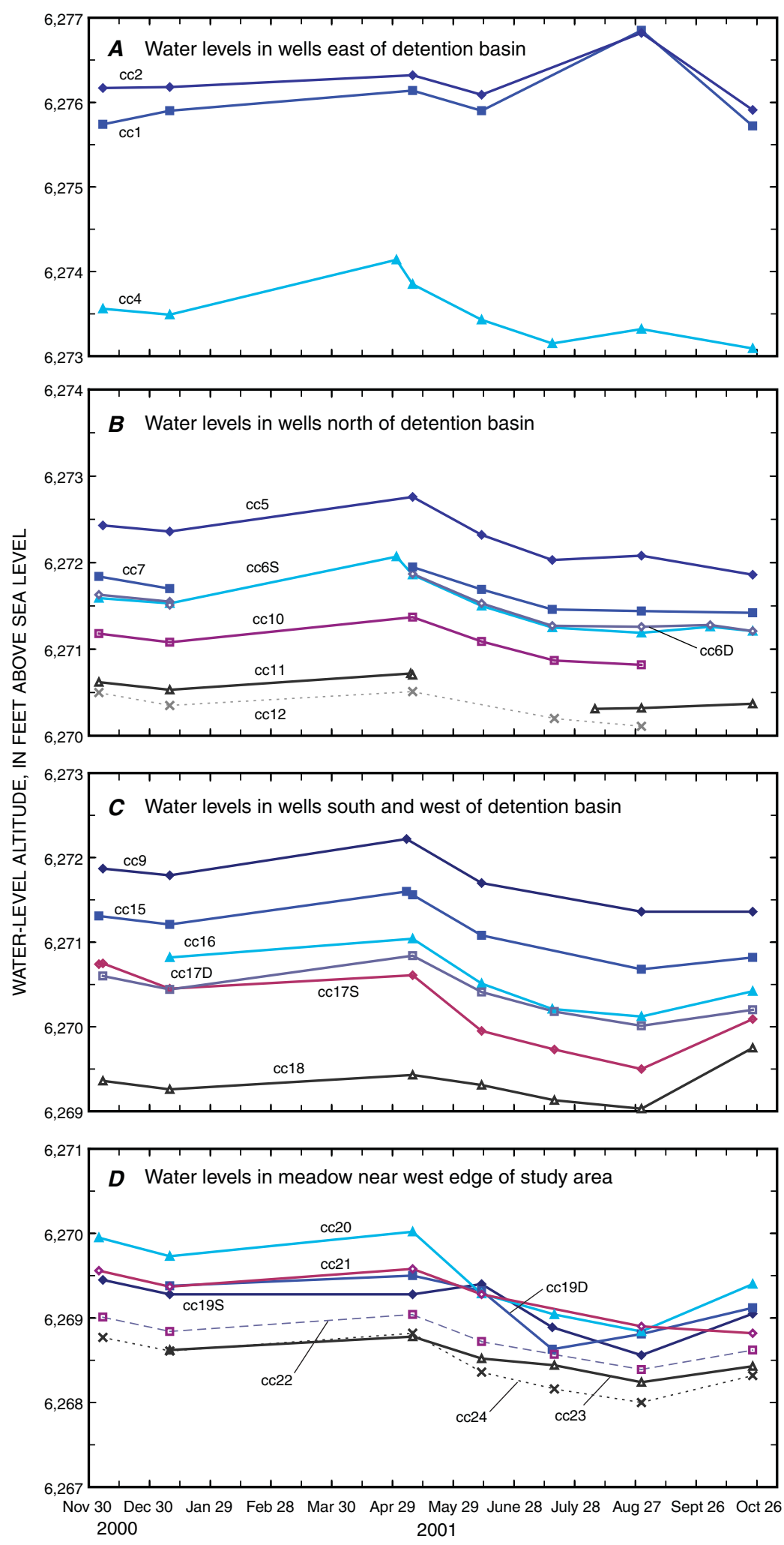

Figure 12. Trends of ground-water levels from periodic measurements in wells without recording pressure transducers in the area of Cattlemans detention basin prior to and during its construction, December 2000 through October 2001: $(A)$ wells east of detention basin; $(B)$ wells north of detention basin; $(C)$ wells south and west of detention basin; $(D)$ wells in meadow near west edge of study area. Location of wells is shown in figure 4. 


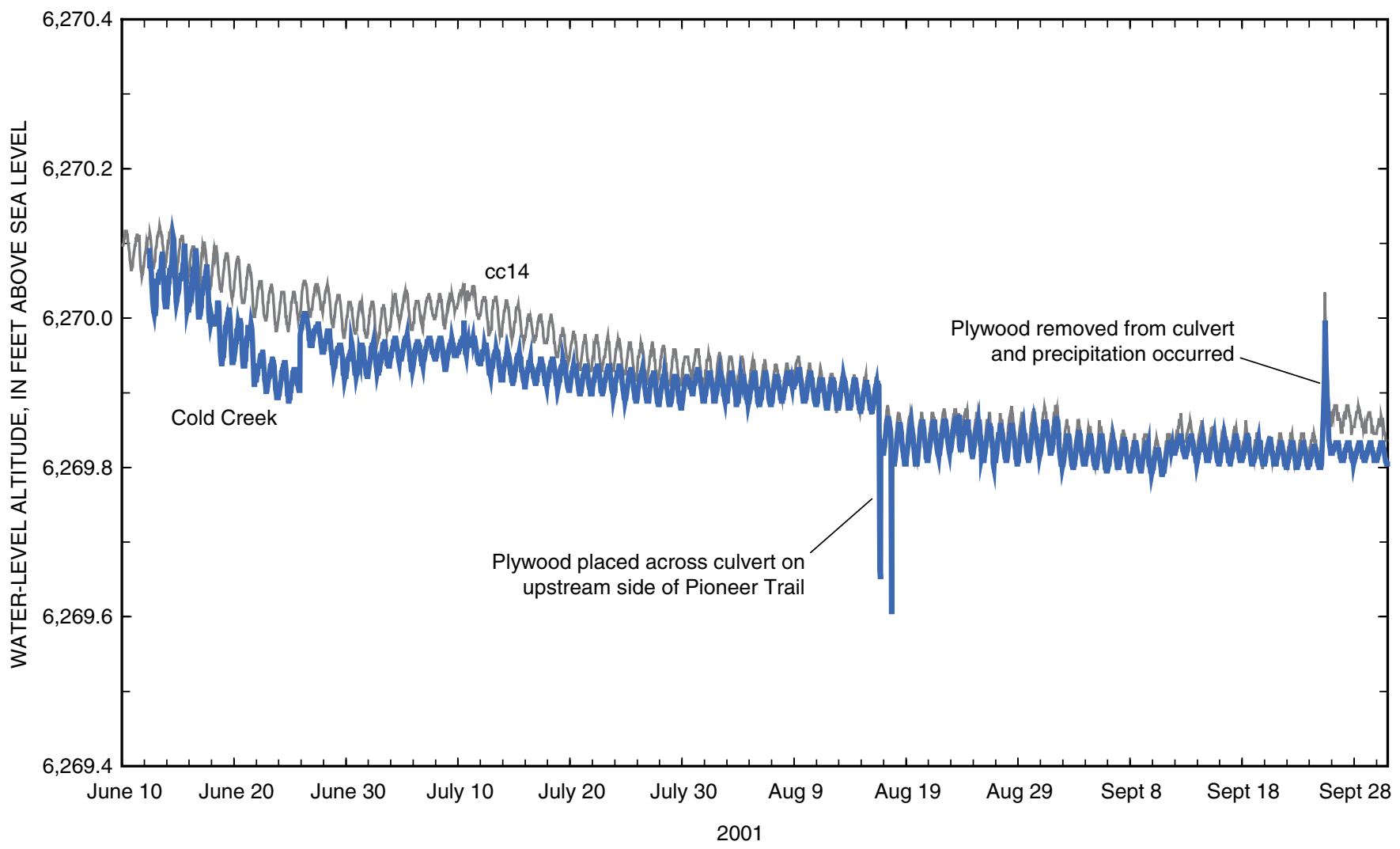

Figure 13. Relation between stage of Cold Creek and ground-water level at well cc14 on west side of Cattlemans detention basin prior to and during its construction, June through September 2001.

\section{Quality of Ground Water, Cold Creek, and Precipitation}

The quality of ground water in the area of the detention basin prior to its construction was mostly dependent on the quality of water from the different sources (precipitation, urban runoff from Pioneer Trail, Montgomery Estates, and Cattlemans Court, inflow from upland areas, and seepage from Cold Creek), the chemical and biological reactions that occurred within the unconsolidated deposits through which ground water flowed, and the residence time of water in the deposits. The detention basin was constructed at the base of the upland area adjacent to the upper edge of a large meadow. The water table beneath the area of the detention basin prior to and during its construction was primarily in the gray silt and sand of the meadow deposits; consequently, lateral ground-water flow from the area of the planned detention basin to nearby Cold Creek was primarily through the meadow deposits.

\section{Chemical Composition}

Dissolved calcium, sodium, and bicarbonate in Cold Creek were about 12 times more than the snow, whereas chloride concentrations were nearly the same (table 3 ). Greater concentrations of dissolved constituents in Cold Creek compared with ephemeral springs is attributed to the dissolution of minerals as water moves through the shallow soil and saprolite (Feth and others, 1964, p. 35). The ephemeral and perennial springs listed in table 3 are from areas of granitic rocks in the Sierra Nevada, some of which are springs that were sampled in the upland areas south of South Lake Tahoe (Feth and others, 1964, table 1). A summary of the chemistry of these springs is listed in table 3 (Feth and others, 1964, table 2). The lack of an increase in chloride concentrations in Cold Creek compared with ephemeral springs and precipitation suggests rapid infiltration of precipitation and minimal evaporation prior to reaching Cold Creek. Like precipitation, water from ephemeral and perennial springs and Cold Creek is a calcium, sodium bicarbonate type. This suggests that granitic rocks in the Cold Creek drainage are the principal source of dissolved constituents in water from the creek.

Ground water in meadow deposits within the study area had higher concentrations of most constituents than either snow or water in Cold Creek (table 3); a notable exception is sulfate. Total dissolved solids in the ground water were 34 times more than snow and about 4 times more than the water in Cold Creek. Total dissolved solids in Cold Creek on September 11, 2001, were 10 times more than that of snow and were similar to that from ephemeral and perennial springs.

The mean silica concentration in ground water was more than 100 times greater than the mean silica concentration in snow. Some of the greatly increased dissolved silica in water pumped from the wells could be caused by dissolution of the silica flour and quartz sand used in well construction; however, 
Table 3. Median and mean concentrations of dissolved constituents in ground water and in Cold Creek in the area of Cattlemans detention basin prior to and during its construction, South Lake Tahoe, California, and in perennial and ephemeral springs in granitic rocks and snow in the Sierra Nevada

[Values are reported to two significant figures unless reported by laboratory to one significant figure. Symbol: --, not determined]

\begin{tabular}{|c|c|c|c|c|c|c|c|c|}
\hline \multirow{3}{*}{ Constituent } & \multicolumn{8}{|c|}{ Concentrations in milligrams per liter } \\
\hline & \multicolumn{2}{|c|}{ Ground water ${ }^{1}$} & \multicolumn{2}{|c|}{$\begin{array}{l}\text { Perennial } \\
\text { springs }^{2}\end{array}$} & \multicolumn{2}{|c|}{$\begin{array}{c}\text { Ephemeral } \\
\text { springs }^{2}\end{array}$} & \multirow{2}{*}{$\begin{array}{c}\begin{array}{c}\text { Cold } \\
\text { Creek }^{3}\end{array} \\
\text { Mean }\end{array}$} & \multirow{2}{*}{$\begin{array}{l}\text { Snow }^{4} \\
\text { Mean }\end{array}$} \\
\hline & Median & Mean & Median & Mean & Median & Mean & & \\
\hline Silica $\left(\mathrm{SiO}_{2}\right)$ & 18 & 18 & 22 & 25 & 13 & 16 & 16 & 0.16 \\
\hline Iron $(\mathrm{Fe})$ & 15 & 19 & .01 & .03 & .02 & .03 & .04 & -- \\
\hline Calcium $(\mathrm{Ca})$ & 10 & 14 & 10 & 10 & 2.6 & 3.1 & 5.5 & .4 \\
\hline Magnesium (Mg) & 1.6 & 2.3 & 1.0 & 1.7 & .5 & .70 & .62 & .17 \\
\hline Sodium $(\mathrm{Na})$ & 25 & 22 & 5.5 & 6.0 & 2.7 & 3.0 & 5.0 & .46 \\
\hline Potassium (K) & 2.0 & 2.5 & 1.4 & 1.6 & 1.0 & 1.1 & .90 & .32 \\
\hline Bicarbonate $\left(\mathrm{HCO}_{3}\right)$ & 100 & 120 & 51 & 55 & 14 & 20 & 30 & 2.9 \\
\hline Sulfate $\left(\mathrm{SO}_{4}\right)$ & .40 & .38 & 1.6 & 2.4 & .6 & 1.0 & 2.2 & .95 \\
\hline Chloride $(\mathrm{Cl})$ & 31 & 31 & .45 & 1.1 & .2 & .50 & .52 & .50 \\
\hline Nitrate $\left(\mathrm{NO}_{3}\right)$ & .24 & .33 & .1 & .28 & .0 & .02 & -- & .07 \\
\hline Dissolved solids & 130 & 160 & 72 & 75 & 29 & 36 & 45 & 4.7 \\
\hline \multicolumn{9}{|c|}{$\begin{array}{l}{ }^{1} \text { Median and mean concentrations are from ground water in the meadow deposits of gray silt and sand (see table 4). Nitrate } \\
\text { concentrations listed in this table were converted from nitrate plus nitrite concentrations listed as nitrogen in table } 6 \text {. Location of } \\
\text { wells is shown in figure } 4 .\end{array}$} \\
\hline \multicolumn{9}{|c|}{$\begin{array}{l}{ }^{2} \text { Median and mean concentrations are from perennial and ephemeral springs that discharge from granitic rocks in the Sierra } \\
\text { Nevada (Feth and others, 1964, table 2). Ground water from the upland areas is assumed to have similar concentrations as the } \\
\text { perennial springs because granitic rocks underlie the upland areas east of the detention basin. }\end{array}$} \\
\hline $\begin{array}{l}{ }^{3} \text { Mean concentration in } \\
\text { upstream of Pioneer Trail } \\
\text { estimated from the differe }\end{array}$ & $\begin{array}{l}\text { vater sample } \\
\text { ear well cc1 } \\
\text { in sum of }\end{array}$ & $\begin{array}{l}\text { from Col } \\
\text { and one ne } \\
\text { ations and }\end{array}$ & $\begin{array}{l}\text { Creek. Mean } \\
\text { well cc14 } \\
\text { nions. }\end{array}$ & $\begin{array}{l}\mathrm{s} \text { based or } \\
\text { fig. } 4 \mathrm{fc}\end{array}$ & $\begin{array}{l}\text { vo samples } \\
\text { ocation of }\end{array}$ & $\begin{array}{l}\text { llected o } \\
\text { lls). Bica }\end{array}$ & $\begin{array}{l}\text { eptember } \\
\text { nate conce }\end{array}$ & $\begin{array}{l}\text { 2001: one } \\
\text { ration was }\end{array}$ \\
\hline
\end{tabular}

dissolved silica concentrations in ground water were similar to concentrations in Cold Creek and ephemeral and perennial springs (table 3). Thus, the dissolved silica concentration in water from the shallow wells likely is caused by dissolution of the abundant silica naturally present in minerals in the unconsolidated deposits.

In contrast to water in Cold Creek and water from ephemeral and perennial springs, ground water in the meadow deposits had higher concentrations of iron, sodium, chloride, and bicarbonate, and lower concentrations of sulfate (table 3). Dissolved nitrate plus nitrite in ground water was similar to dissolved nitrate from the perennial springs (Feth and others, 1964), indicating that dissolved nitrate in ground water occurs naturally. The dissolved iron concentrations in the meadow deposits were about 500 times greater and chloride was more than 30 times greater than dissolved concentrations in Cold Creek or water from the ephemeral and perennial springs. The median and mean sulfate concentrations in the meadow deposits were $0.4 \mathrm{mg} / \mathrm{L}$ (table 3 ) and dissolved oxygen was near the detection limit $(<0.3 \mathrm{mg} / \mathrm{L}$; see table 6$)$. The low dissolved oxygen concentrations indicate that shallow ground water in the meadow is largely anoxic. The lack of oxygen is likely the result of microbial oxidation of organic matter in the meadow deposits. The anoxic conditions allow for iron and manganese to be dissolved at higher concentrations than oxygenated ground water.

Dissolved chloride concentrations in ground water from the meadow deposits and deeper sand and gravel correlate well to total dissolved solids, whereas bromide concentrations (although much lower) show no relation (fig. 14). These two anions have similar sources and both have similar geochemical behavior. Because bromide does not show a correlation to total dissolved solids, the increase in chloride cannot be explained by concentration resulting from evapotranspiration of ground water. The chloride in the ground water probably was from a source other than the unconsolidated deposits. One likely source of chloride and sodium is from the application of a mixture of road cinders and salt (sodium chloride) at proportions of 1 part salt to 4 parts cinders along Pioneer Trail and streets in Montgomery Estates subdivision during the winter (Jennifer Quickel, Tahoe Engineering Division, El Dorado County Department of Transportation, written commun., 2003). 


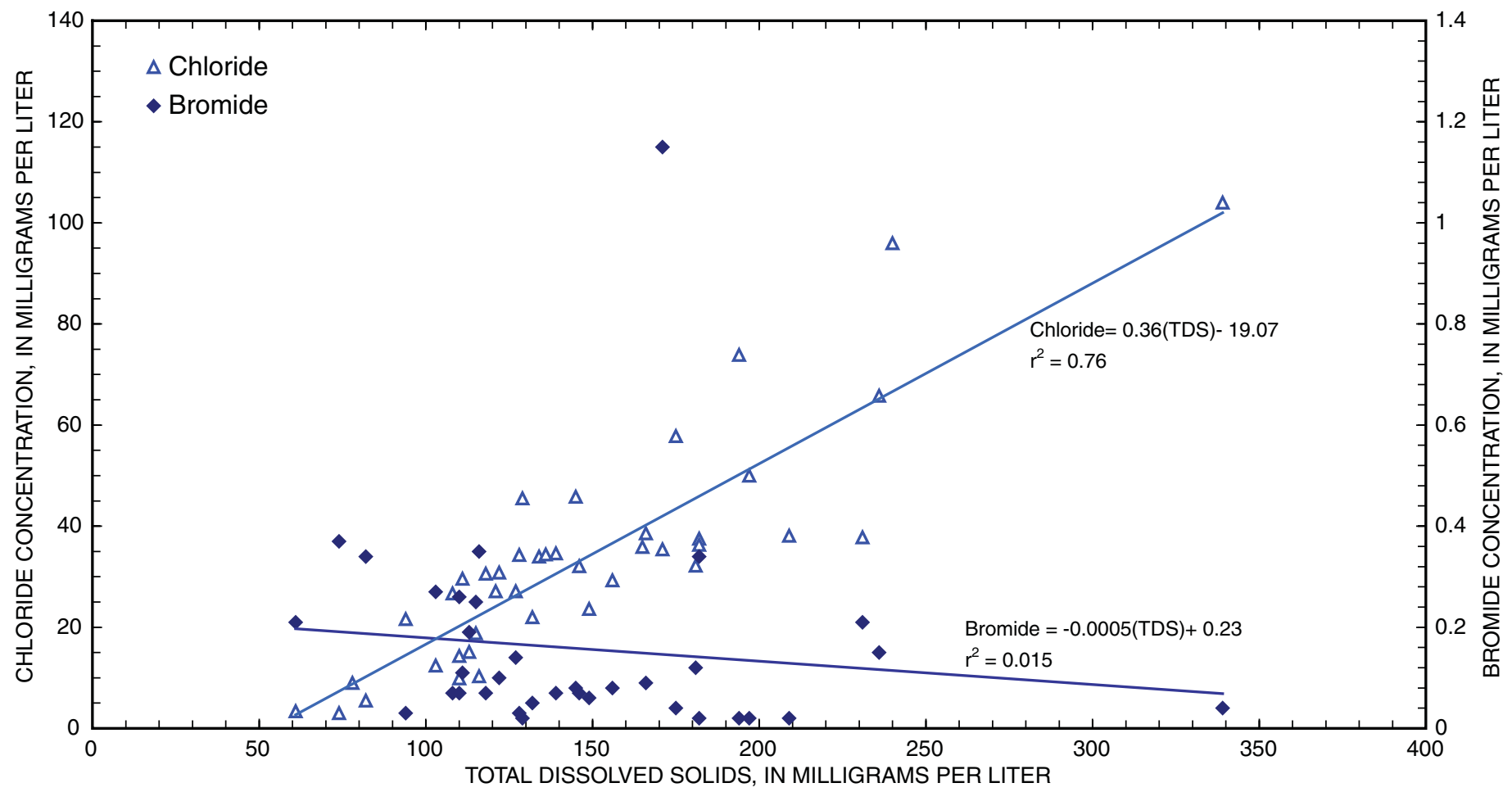

Figure 14. Relation between total dissolved solids and dissolved chloride and bromide in ground water in the area of Cattlemans detention basin prior to and during its construction, January to November 2001.

The chemical composition of water in shallow meadow deposits was similar to the chemical composition of water in the deeper brown sand and gravel. Exceptions include sulfate concentrations, which were generally higher, and dissolved iron and organic carbon, which were about 2 times less (table 4). The range in dissolved concentrations of most constituents generally was greater in the meadow deposits than in the deeper sand and gravel. Iron concentrations in the meadow deposits ranged from 0.66 to $60 \mathrm{mg} / \mathrm{L}$, whereas concentrations in the deeper sand and gravel ranged from 0.035 to $19 \mathrm{mg} / \mathrm{L}$ (table 4). Similarly, dissolved organic carbon ranged from 2.5 to $14 \mathrm{mg} / \mathrm{L}$ in the meadow deposits, and from 1.2 to $5.8 \mathrm{mg} / \mathrm{L}$ in the sand and gravel (table 4). The greater dissolved organic carbon in ground water from meadow deposits likely was caused by the greater availability of organic material in the meadow deposits.

Except for aluminum, barium, manganese, molybdenum, and uranium, concentrations of most dissolved trace elements in ground water were less than $2 \mu \mathrm{g} / \mathrm{L}$ (table 5). Similar to iron, concentrations of manganese and aluminum were lower in ground water from the deeper sands and gravels compared with ground water from the shallow meadow deposits.

\section{Distribution of Total Dissolved Solids, Chloride, and Iron}

Concentrations of total dissolved solids, chloride, and iron for April-May 2001, shortly after peak ground-water levels, were used to illustrate areal distributions of dissolved constituents within the meadow deposits. The highest measured dissolved solids concentration of $339 \mathrm{mg} / \mathrm{L}$ was at well cc21 (fig. 15A). In the area of the planned detention basin, concentrations of dissolved solids were higher at wells cc3S and cc8S than at wells closer to Cold Creek (wells cc10, cc11, cc12, cc13S, and cc14) or from well cc9 at the end of Cattlemans Court. Chloride concentrations also were highest at well cc21 and were nearly the same in wells cc3S, cc9, cc15, and cc14 (fig. 15B). The nearly uniform chloride concentrations in the vicinity of the planned detention basin suggest that chloride is well dispersed in the shallow meadow deposits. Chloride concentrations were least in wells cc11 and cc12 and could result from mixing with the more dilute water in Cold Creek.

Dissolved iron was analyzed as part of the nutrient analyses, consequently more wells were sampled for dissolved iron than for total dissolved solids and chloride (fig. 15C). The distribution of iron shows a similar pattern-highest concentration of iron was measured in well cc21 and the lowest was next to Cold Creek at well cc7. The low dissolved iron concentration in 
Table 4. Concentrations of principal dissolved inorganic constituents and dissolved organic carbon in ground water in the area of Cattlemans detention basin prior to and during its construction, South Lake Tahoe, California, January to November 2001

[Abbreviation: microsiemens per centimeter, $\mu \mathrm{S} / \mathrm{cm}$. Values are reported to two significant figures unless reported by laboratory to one significant figure.]

\begin{tabular}{|c|c|c|c|c|c|c|c|c|}
\hline \multirow[t]{2}{*}{ Constituent } & \multicolumn{4}{|c|}{$\begin{array}{l}\text { Ground water in meadow deposits }{ }^{1} \\
\text { (concentrations in milligrams per liter, } \\
\text { except as noted) }\end{array}$} & \multicolumn{4}{|c|}{$\begin{array}{l}\text { Deeper ground water in sand and gravel }{ }^{2} \\
\text { (concentrations in milligrams per liter, } \\
\text { except as noted) }\end{array}$} \\
\hline & Minimum & Median & Maximum & Mean & Minimum & Median & Maximum & Mean \\
\hline Silica $\left(\mathrm{SiO}_{2}\right)$ & 12 & 18 & 28 & 18 & 15 & 22 & 26 & 20 \\
\hline Iron $(\mathrm{Fe})$ & 0.66 & 15 & 60 & 19 & 0.035 & 5.9 & 19 & 8.3 \\
\hline Calcium $(\mathrm{Ca})$ & 4.5 & 10 & 32 & 14 & 5.6 & 11 & 20 & 11 \\
\hline Magnesium (Mg) & .68 & 1.6 & 5.3 & 2.3 & .82 & 1.9 & 3.2 & 1.9 \\
\hline Sodium (Na) & 6.7 & 25 & 43 & 22 & 15 & 26 & 63 & 31 \\
\hline Potassium (K) & .67 & 2.0 & 7.6 & 2.5 & 1.2 & 1.7 & 2.2 & 1.7 \\
\hline Bicarbonate $\left(\mathrm{HCO}_{3}\right)$ & 46 & 100 & 270 & 120 & 60 & 73 & 99 & 77 \\
\hline Sulfate $\left(\mathrm{SO}_{4}\right)$ & .1 & .4 & .8 & .38 & .3 & 1.1 & 3.4 & 1.4 \\
\hline Chloride $(\mathrm{Cl})$ & 3.0 & 31 & 104 & 31 & 5.5 & 33 & 96 & 40 \\
\hline Bromide (Br) & $<.02$ & .12 & 1.2 & .19 & $<.02$ & .06 & .34 & .1 \\
\hline Fluoride (F) & $<.2$ & $<.2$ & $<.2$ & $<.2$ & $<.2$ & $<.2$ & $<.2$ & $<.2$ \\
\hline Organic carbon (DOC) & 2.5 & 5.2 & 14 & 5.5 & 1.2 & 2.0 & 5.8 & 2.2 \\
\hline pH (standard units) & 5.8 & 6.5 & 6.9 & 6.5 & 6.2 & 6.5 & 6.8 & 6.5 \\
\hline Specific conductance $(\mu \mathrm{S} / \mathrm{cm})$ & 84 & 260 & 550 & 280 & 160 & 260 & 350 & 270 \\
\hline Dissolved solids & 61 & 130 & 340 & 160 & 82 & 150 & 240 & 150 \\
\hline
\end{tabular}

\footnotetext{
${ }^{1}$ Water was sampled from shallow wells between January and November 2001. Values are based on 34 samples collected from wells 3S, 8S, 9, $10,11,12,13 \mathrm{~S}, 14,15$, and 21, except dissolved iron, which is based on 70 samples collected from wells $1,2,3 \mathrm{~S}, 6 \mathrm{~S}, 7,8 \mathrm{~S}, 9$, 10, 11, 12, 13S, 14, $15,16,17 \mathrm{~S}, 18,19 \mathrm{~S}, 20,21,22,23$, and 24 . Well name has been abbreviated by omitting the "cc" designation. Shallow wells are screened in meadow deposits of gray silt and sand with lenses of sand and gravel. Location of wells is shown in figure 4.

${ }^{2}$ Water was sampled from deeper wells between January and November 2001. Values are based on 12 samples from wells 3D, 8D, and 13D except for dissolved iron, which is based on 21 samples collected from wells 3D, 6D, 8D, 13D, 17D, and 19D. Well name has been abbreviated by omitting the "cc" designation. Deeper wells are screened in the brown to yellow brown sand and gravel with lenses of silt and sand. Location of wells is shown in figure 4.
}

well cc7 supports water-level measurements that indicate Cold Creek was supplying water to the meadow deposits at or near the well (fig. 10). Dissolved iron concentrations in wells next to Cold Creek were highest at well cc14, which is consistent with water-level measurements that indicate ground water is discharging to Cold Creek near the well.

Concentrations of dissolved constituents also differed between ground water in the shallow meadow deposits and in the deeper sand and gravel (fig. 16). Total dissolved solids were lower in the deeper wells cc3D and cc8D when compared with total dissolved solids in wells cc3S and cc8S, whereas total dissolved solids in well cc13D were higher than in well cc13S

(fig. 16A). Total dissolved solids in well cc14 are higher than in well cc13S suggesting that dissolved solids near the water table could be higher than that measured at well cc13S. Chloride concentrations were consistently higher in the deeper sand and gravel than in the shallow meadow deposits (fig. 16B). Chloride was highest in well cc3D next to Pioneer Trail suggesting that the application of salt mixed with cinders was contributing chloride to the deeper sand and gravel. Iron concentrations in the deeper sand and gravel were low at well cc3D and highest in the shallow meadow deposits at well cc8S (fig. 16C). Similar to total dissolved solids, iron concentration in well cc14 was higher than in well cc13S. This suggests that dissolved constituents vary considerably in the meadow deposits depending on organic content, and chemical and biological reactions.

\section{Distribution of Nutrients and Organic Carbon}

Concentrations of the different forms of dissolved nitrogen and phosphorus, and concentrations of dissolved iron, and organic carbon were generally higher in the meadow deposits than in the deeper sand and gravel (table 6). Ammonia plus organic nitrogen were the dominant forms of nitrogen and had a maximum concentration of $18 \mathrm{mg} / \mathrm{L}$. Median concentrations of dissolved nitrogen, phosphorus, and organic carbon in the meadow deposits were higher than those in the deeper sand and gravel. 
Table 5. Concentrations of dissolved inorganic trace elements in ground water in the area of Cattlemans detention basin prior to and after its construction, South Lake Tahoe, California, January to November 2001

[Values are reported to two significant figures unless reported by laboratory to one significant figure.]

\begin{tabular}{|c|c|c|c|c|c|c|c|c|}
\hline \multirow{2}{*}{ Constituent } & \multicolumn{4}{|c|}{$\begin{array}{l}\text { Ground water in meadow deposits } \\
\text { (concentrations in micrograms per liter) }\end{array}$} & \multicolumn{4}{|c|}{$\begin{array}{l}\text { Deeper ground water in sand and gravel } \\
\text { (concentrations in micrograms per liter) }\end{array}$} \\
\hline & Minimum & Median & Maximum & Mean & Minimum & Median & Maximum & Mean \\
\hline Aluminum (Al) & 4 & 10 & 65 & 21 & 1 & 2 & 6 & 2.5 \\
\hline Antimony (Sb) & $<0.05$ & $<0.05$ & $<0.05$ & $<0.05$ & $<0.05$ & $<0.05$ & 0.09 & $<0.05$ \\
\hline Arsenic (As) & $<2$ & $<2$ & 5 & $<2$ & $<2$ & $<2$ & 2.6 & $<2$ \\
\hline Barium (Ba) & 6.1 & 22 & 100 & 33 & 8.2 & 20 & 77 & 27 \\
\hline Beryllium (Be) & $<.06$ & $<.06$ & $<.06$ & $<.06$ & $<.06$ & $<.06$ & $<.06$ & $<.06$ \\
\hline Cadmium (Cd) & $<.04$ & $<.04$ & .14 & .05 & $<.04$ & $<.04$ & .12 & .05 \\
\hline Chromium $(\mathrm{Cr})$ & $<.8$ & $<.8$ & 1.7 & $<.8$ & $<.8$ & $<.8$ & $<.8$ & $<.8$ \\
\hline Cobalt $(\mathrm{Co})$ & .04 & .82 & 3.3 & .94 & .5 & .66 & 1.5 & .83 \\
\hline Copper $(\mathrm{Cu})$ & $<.6$ & $<.6$ & $<.6$ & $<.6$ & $<.6$ & $<.6$ & $<.6$ & $<.6$ \\
\hline Lead $(\mathrm{Pb})$ & $<.08$ & $<.08$ & .44 & .09 & $<.08$ & $<.08$ & $<.08$ & $<.08$ \\
\hline Manganese (Mn) & 59 & 230 & 1,500 & 390 & 38 & 130 & 280 & 130 \\
\hline Molybdenum (Mo) & 1.7 & 6.0 & 39 & 8.5 & 1.9 & 11 & 24 & 11 \\
\hline Nickel (Ni) & $<.06$ & $<.06$ & .49 & .15 & $<.06$ & $<.06$ & .35 & .11 \\
\hline Selenium (Se) & $<2.4$ & $<2.4$ & $<2.4$ & $<2.4$ & $<2.4$ & $<2.4$ & $<2.4$ & $<2.4$ \\
\hline Silver (Ag) & $<1$ & $<1$ & $<1$ & $<1$ & $<1$ & $<1$ & $<1$ & $<1$ \\
\hline Uranium(U) & .7 & 2.1 & 30 & 4.4 & 1.8 & 3.7 & 11 & 4.4 \\
\hline Zinc $(\mathrm{Zn})$ & $<2$ & $<2$ & $<2$ & $<2$ & $<1$ & $<1$ & $<1$ & $<1$ \\
\hline
\end{tabular}

\footnotetext{
${ }^{1}$ Water was sampled from shallow wells between January and November 2001. Values are based on 34 samples collected from wells cc3S, cc8S, cc9, cc10, cc11, cc12, cc13S, cc14, cc15, and cc21. Shallow wells are screened in meadow deposits of gray silt and sand with lenses of sand and gravel. Location of wells is shown in figure 4.

${ }^{2}$ Water was sampled from deeper wells between January and November 2001. Values are based on 12 samples from wells cc3D, cc8D, and cc13D. Deeper wells are screened in the brown to yellow brown sand and gravel with lenses of silt and sand. Location of wells is shown in figure 4.
}

Concentrations of dissolved ammonia plus organic nitrogen, phosphorus, and organic carbon for samples collected in late April and early May 2001, shortly after peak ground-water levels, from ground water in the meadow deposits do not show any consistent areal patterns (fig. 17). This suggests that variations in concentration likely are controlled by variations in the chemical and biological reactions within the meadow deposits. Ammonia plus organic nitrogen ranged from $0.07 \mathrm{mg} / \mathrm{L}$ at well cc7 next to Cold Creek to $16 \mathrm{mg} / \mathrm{L}$ as well cc $8 \mathrm{~S}$ in the middle of the detention basin site (fig. 17A). With the exception of three wells, ammonia plus organic nitrogen concentrations were less than $2 \mathrm{mg} / \mathrm{L}$. Dissolved phosphorus was more uniform with concentrations ranging from 0.04 to $0.32 \mathrm{mg} / \mathrm{L}$ (fig. 17B). Dissolved organic carbon concentrations ranged from 3.2 to $7.7 \mathrm{mg} / \mathrm{L}$ (fig. 17C).

Ammonia plus organic nitrogen, phosphorus, and organic carbon concentrations were consistently less in the deeper sand and gravel than in the meadow deposits (fig. 18). Ammonia plus organic nitrogen and dissolved organic carbon show no consistent change in the direction of ground-water flow again suggesting that local variations in the chemical and biological reactions within the meadow deposits are controlling the variation in nitrogen concentrations; however, dissolved phosphorus increased in both the meadow deposits and in the deeper sand and gravel along the direction of ground-water flow. This suggests that phosphorus concentrations in ground water may be controlled by the dissolution of phosphorus-containing minerals in the unconsolidated deposits.

The two highest concentrations of dissolved organic carbon in ground water from the meadow deposits were from wells cc3S and cc8S and are coincident with the highest concentrations of total dissolved nitrogen (sum of all nitrogen compounds, fig. 19). These wells are located in an area where thick fill was placed over the meadow deposits. Ground water from wells near the edge of the fill (wells cc9, cc10, cc13S, and cc15), and from wells along Cold Creek and in the meadow west of the planned detention basin (wells cc11, cc12, cc14, and cc21) also suggest that total dissolved nitrogen may be correlated to dissolved organic carbon but the increase in total dissolved nitrogen compared with the increase in dissolved organic carbon is much less than that at wells cc $3 \mathrm{~S}$ and cc8S. The correlation between dissolved nitrogen and dissolved organic carbon in the meadow deposits may be nonlinear as suggested by the data shown on figure 19. The higher dissolved nitrogen and organic carbon at well cc8S could be from the decomposition of vegetation buried by the fill. 


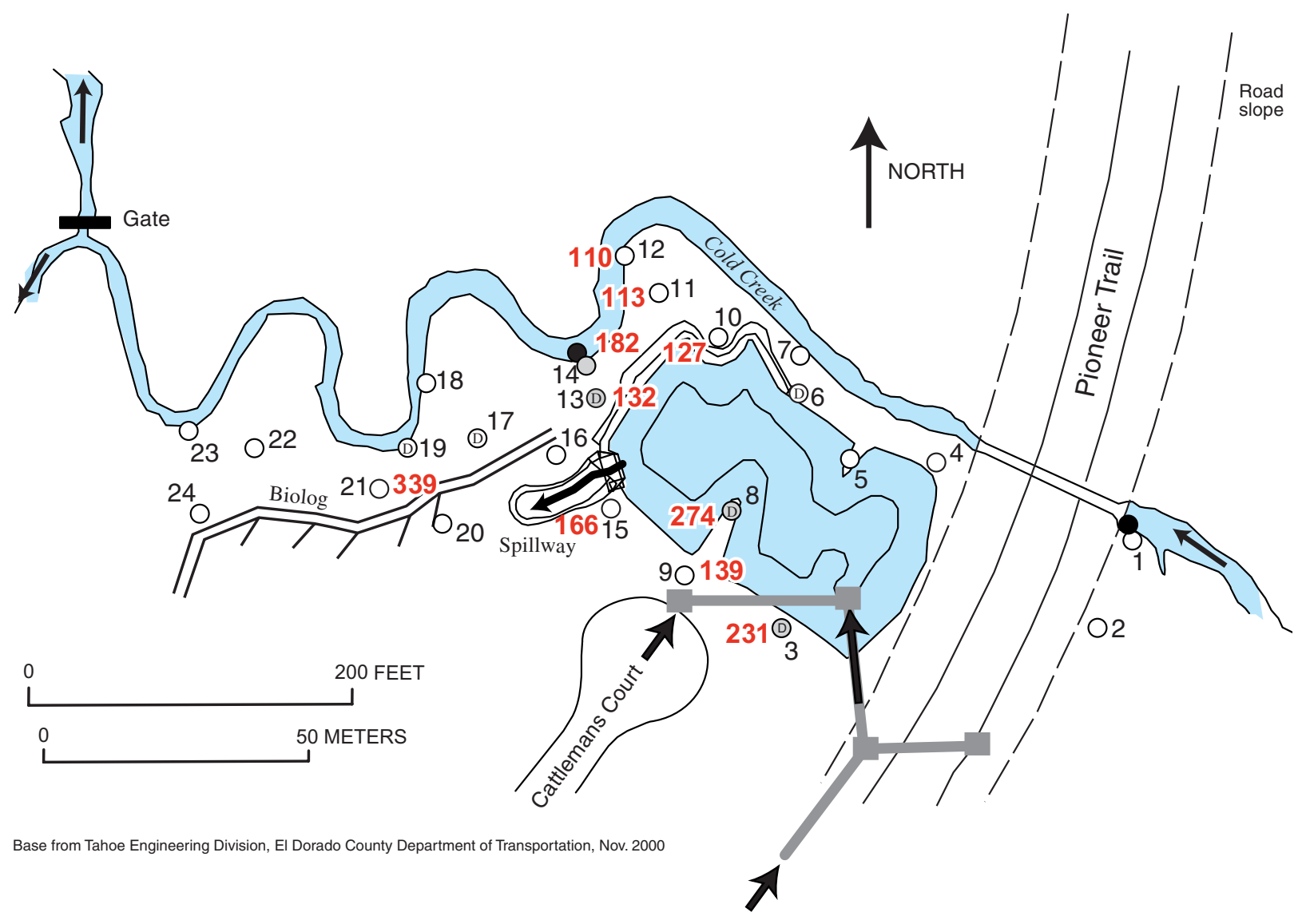

EXPLANATION

339 Total dissolved solids-In milligrams per liter

Ground-water level recorder

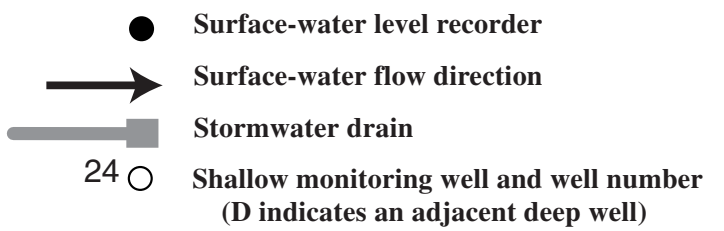

Figure 15. Distribution of $(A)$ total dissolved solids, $(B)$ dissolved chloride, and $(C)$ dissolved iron concentrations in ground water from meadow deposits in the area of Cattlemans detention basin prior to its construction, late April and May 2001. Well name listed in table 1 has been abbreviated by omitting the "cc" designation. 
B Dissolved chloride, late April-May 2001

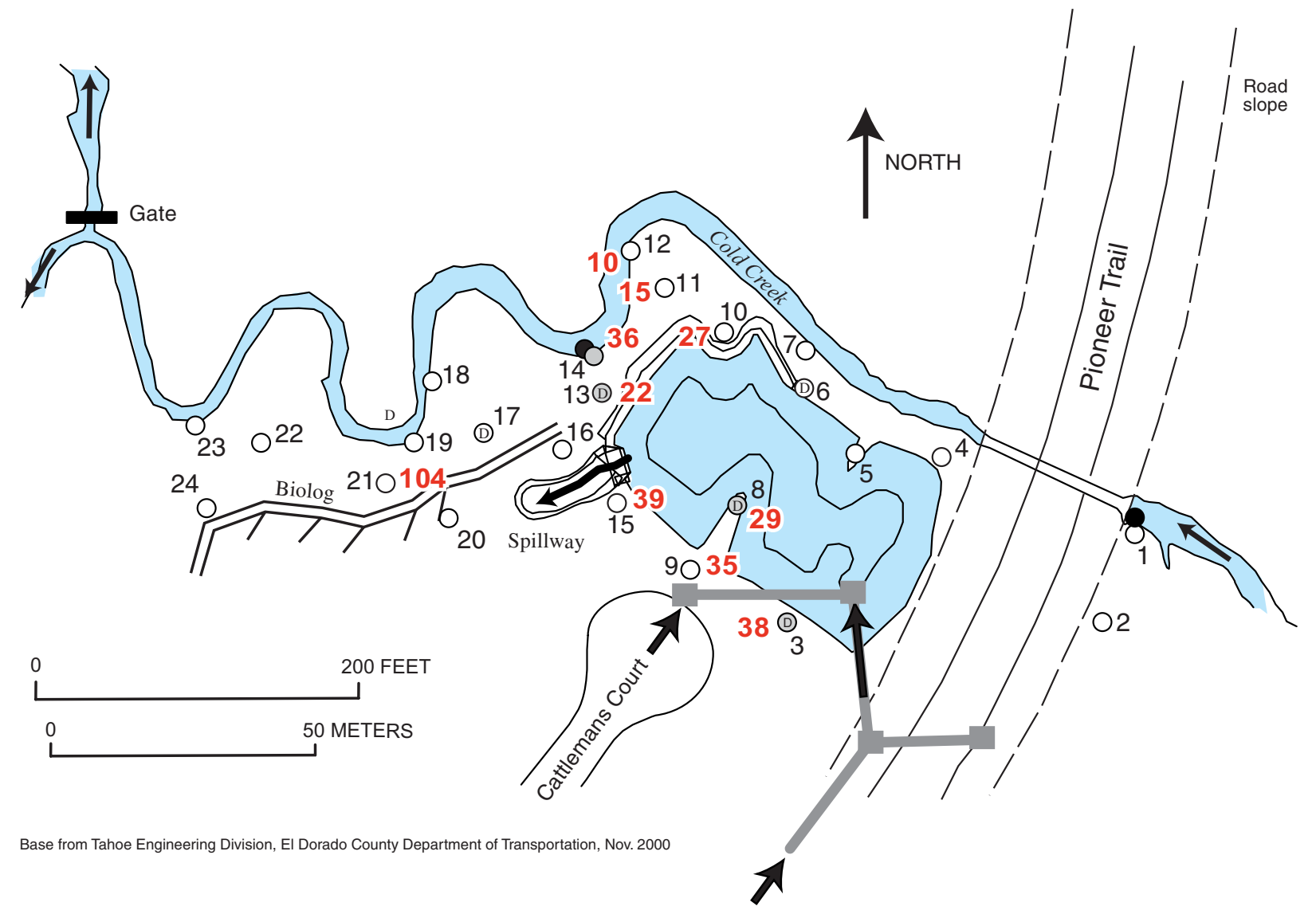

\section{EXPLANATION}

104 Dissolved chloride - In milligrams per liter

Ground-water level recorder

Surface-water level recorder

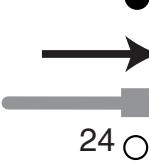

Surface-water flow direction

Stormwater drain

$24 \bigcirc$ Shallow monitoring well and well number

(D indicates an adjacent deep well)

Figure 15.-Continued. 
C Dissolved iron, late April-May 2001
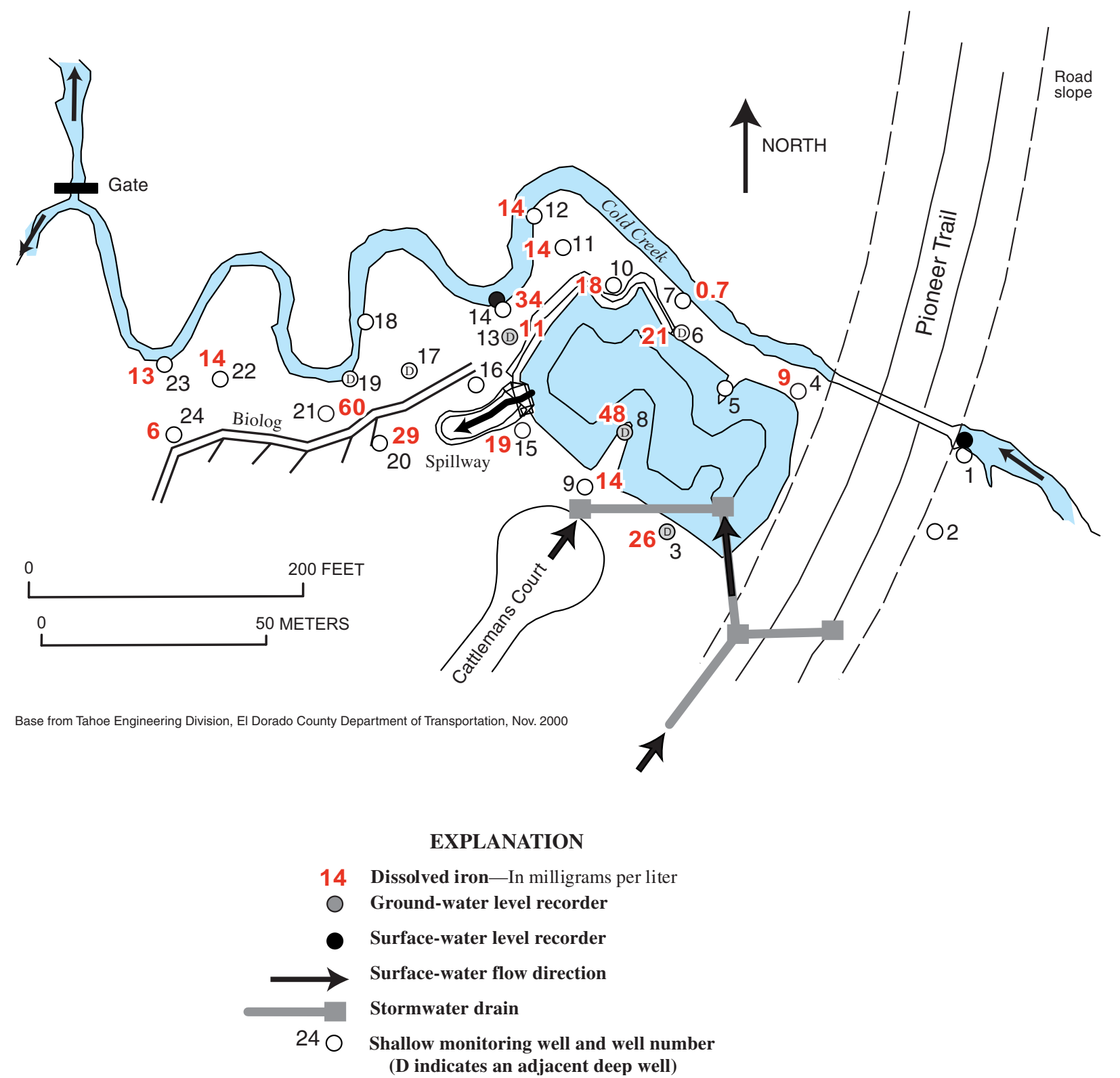

Figure 15.-Continued. 


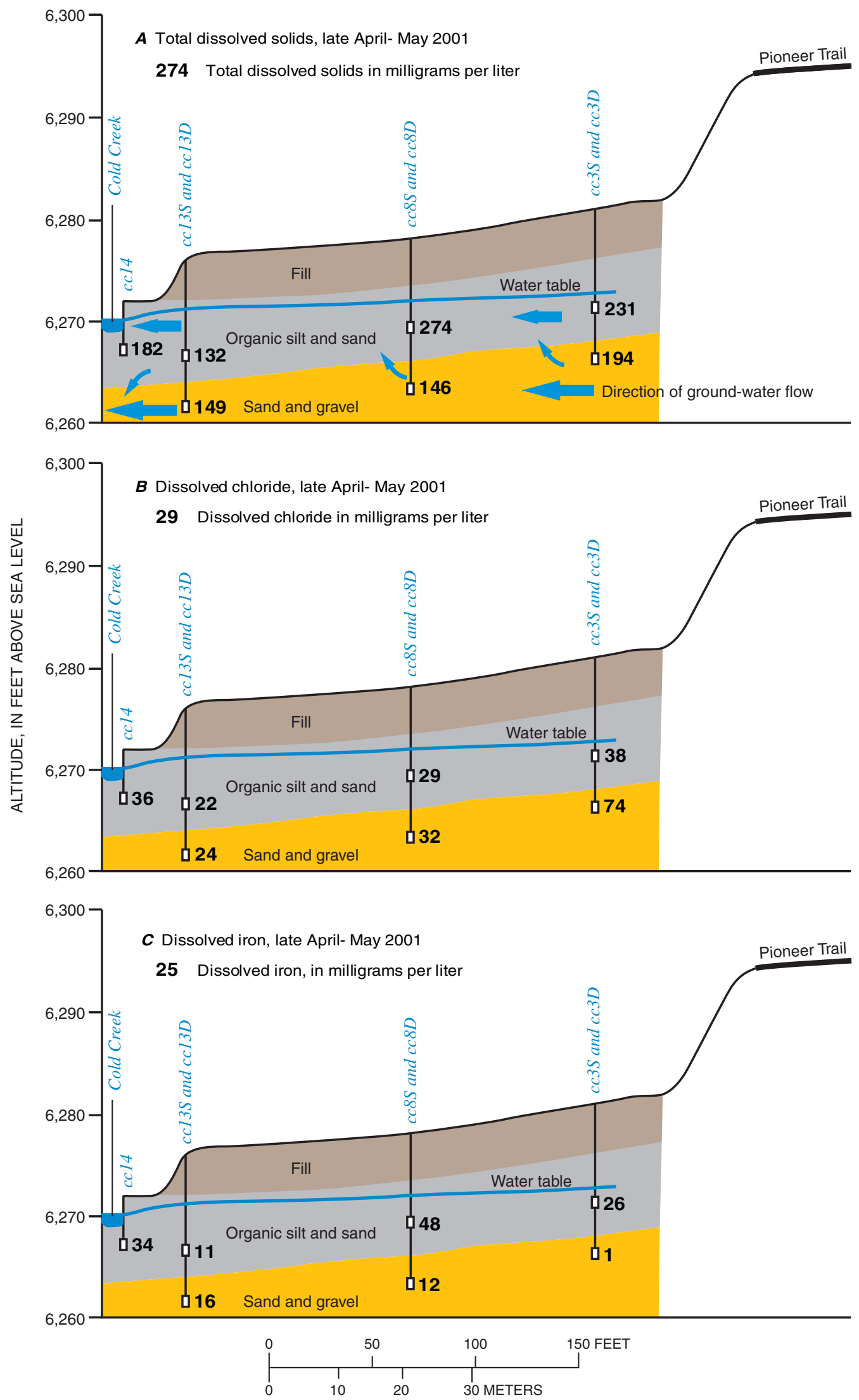

Figure 16. Vertical sections showing distribution of $(A)$ total dissolved solids, $(B)$ dissolved chloride, and $(C)$ dissolved iron concentrations in ground water beneath Cattlemans detention basin prior to its construction, late April and May 2001. 
Table 6. Concentrations of dissolved nutrients in ground water in vicinity of Cattlemans detention basin prior to and during its construction, South Lake Tahoe, California, January to November 2001

[Values are reported to two significant figures unless reported by laboratory to one significant figure.]

\begin{tabular}{|c|c|c|c|c|c|c|c|c|}
\hline \multirow{2}{*}{ Nutrient } & \multicolumn{4}{|c|}{$\begin{array}{l}\text { Ground water in meadow deposits } \\
\text { (concentrations in milligrams per liter) }\end{array}$} & \multicolumn{4}{|c|}{$\begin{array}{l}\text { Deeper ground water in sand and grave }{ }^{2} \\
\text { (concentrations in milligrams per liter) }\end{array}$} \\
\hline & Minimum & Median & Maximum & Mean & Minimum & Median & Maximum & Mean \\
\hline Ammonia $\left(\mathrm{NH}_{3}\right)$ as nitrogen $(\mathrm{N})$ & 0.004 & 0.31 & 18 & 1.5 & 0.014 & 0.062 & 0.64 & 0.15 \\
\hline Nitrate $\left(\mathrm{NO}_{3}\right)+$ nitrite $\left(\mathrm{NO}_{2}\right)$ as $\mathrm{N}$ & .002 & .054 & 0.33 & 0.075 & .004 & .043 & .12 & .047 \\
\hline Orthophosphorus, as $\mathrm{P}$ & .001 & .02 & .34 & .069 & .001 & .005 & .40 & .039 \\
\hline Organic carbon (DOC) & 2.5 & 5.2 & 14 & 5.5 & 1.2 & 2.0 & 5.8 & 2.2 \\
\hline Dissolved oxygen (DO) & $<.3$ & $<.3$ & 2.4 & .4 & $<.3$ & .4 & 1.0 & .5 \\
\hline
\end{tabular}

${ }^{1}$ Water was sampled from shallow wells between January and November 2001. Values are based on 70 samples collected from wells 1, 2, 3S, 6S, 7, 8S, 9, 10, $11,12,13 \mathrm{~S}, 14,15,16,17 \mathrm{~S}, 18,19 \mathrm{~S}, 20,21,22,23$, and 24 except for organic carbon and dissolved oxygen which are based on 34 samples from wells $3 \mathrm{~S}, 8 \mathrm{~S}$, $10,11,12,13 \mathrm{~S}, 14,15$, and 21 . Well name has been abbreviated by omitting the "cc" designation. Shallow wells are screened in meadow deposits of gray silt and sand with lenses of sand and gravel. Location of wells is shown in figure 4.

${ }^{2}$ Water was sampled from deeper wells between January and November 2001. Values are based on 21 samples collected from wells 3D, 6D, 8D, 13D, 17D, and 19D except organic carbon and dissolved oxygen, which are based on 34 samples from wells $3 \mathrm{~S}, 8 \mathrm{~S}, 10,11,12,13 \mathrm{~S}, 14,15$, and 21. Well name has been abbreviated by omitting the "cc" designation. Deeper wells are screened in the brown to yellow-brown sand and gravel with lenses of finer-textured silt and sand. Location of wells is shown in figure 4.

\section{Seasonal Variations}

Concentrations of dissolved calcium, sodium, iron, bicarbonate, and chloride varied during the year among ground water in the meadow deposits from four wells sampled across the detention basin site (fig. 20). Changes in sodium, calcium, and iron concentrations were not consistent among the four wells. In general, sodium was the dominant cation in wells cc $3 \mathrm{~S}$ and cc13S; iron was the dominant cation at well cc8S; and iron was dominant during the winter and spring and sodium during the summer and fall at well cc14. Concentrations of sodium, calcium, and iron remained unchanged at well cc8S. Sodium concentrations varied the least at all four wells whereas calcium was most variable at well cc3S and iron was most variable at well cc14. Bicarbonate concentrations were nearly constant at wells cc $8 \mathrm{~S}$ and cc14, decreased slightly after the spring at well cc3S, and increased from winter to summer at well cc13S. Bicarbonate concentrations were highest at well cc8S (exceeded $260 \mathrm{mg} / \mathrm{L}$ ) and lowest at well cc13S (ranged from 65 to $100 \mathrm{mg} / \mathrm{L}$ ). Chloride concentrations were nearly constant at wells cc3S and cc8S; generally followed the same trend as bicarbonate at well cc13S; and slowly decreased from spring to fall at well cc14.

Concentrations of dissolved calcium, sodium, iron, bicarbonate, and chloride generally varied more during the year among ground water in the deeper sand and gravel sampled from three wells compared with ground water in the meadow deposits (fig. 21). Changes in sodium, calcium, and iron concentrations were not consistent among the three deeper wells and were not consistent with changes in the meadow deposits. Calcium, iron, and bicarbonate concentrations in the deeper sand and gravel at wells cc3D and cc8D were less than concentrations in adjacent wells in the meadow deposits (compare cc3D and cc8D in fig. 21 to $\operatorname{cc} 3 \mathrm{~S}$ and cc $8 \mathrm{~S}$ in fig. 20). Although changes in concentrations during the year were not the same for wells cc13D and cc13S, concentrations of calcium, sodium, iron, bicarbonate, and chloride were similar between ground water from the meadow deposits and the deeper sand and gravel (figs. $20 C$ and $21 C$ ). Iron concentrations increased in the deeper sand and gravel along the general direction of ground-water flow. Variations of dissolved constituents among ground water in the meadow deposits and in the deeper sand and gravel and through time suggests that concentrations at any one well is affected by a variety of processes that include; subsurface flow from upland areas, recharge through the fill materials that overlie the meadow deposits, flow between the meadow deposits and deeper sand and gravel, and chemical and biological reactions within the unconsolidated deposits.

Concentrations of sodium and chloride in the deeper wells were much higher at well cc3D than at wells cc8D and cc13D. The water at well cc3D was dominated by sodium and chloride in May and July 2001. Because of the close proximity of well cc3D to Pioneer Trail and because the shallow meadow deposits do not extend into the upland area, the likely source of the sodium and chloride is the application of salt mixed with cinders during winter along surface roads. The peak in chloride concentrations lags a couple of months behind the peak in ground-water levels measured in well cc3D (see fig. 11). The later chloride peak may correspond to the time for chloride to travel from its source area along Pioneer Trail and the Montgomery Estates subdivision to well cc3D. 
A Ammonia plus organic nitrogen, late April-May 2001

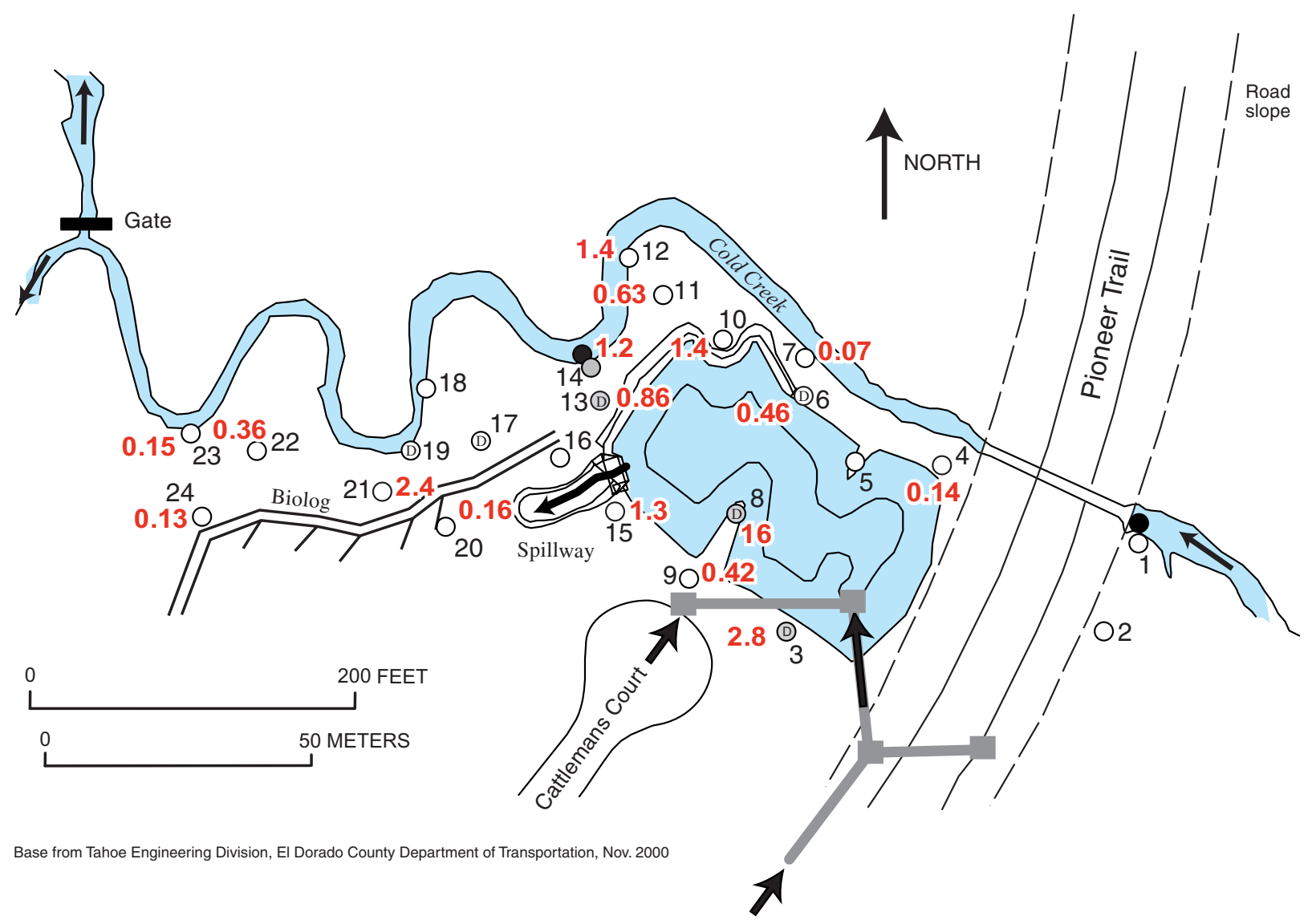

\section{EXPLANATION}

2.4 Ammonia plus organic nitrogen as nitrogen-In milligrams per liter

Ground-water level recorder

- Surface-water level recorder

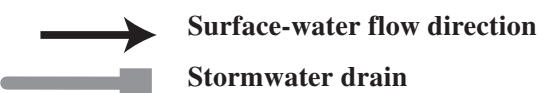

$24 \bigcirc$ Shallow monitoring well and well number (D indicates an adjacent deep well)

Figure 17. Distribution of $(A)$ dissolved ammonia plus organic nitrogen, $(B)$ dissolved phosphorus, and $(C)$ dissolved organic carbon concentrations in ground water from meadow deposits in the area of Cattlemans detention basin prior to its construction, late April and May 2001. Well name listed in table 1 has been abbreviated by omitting the "cc" designation. 


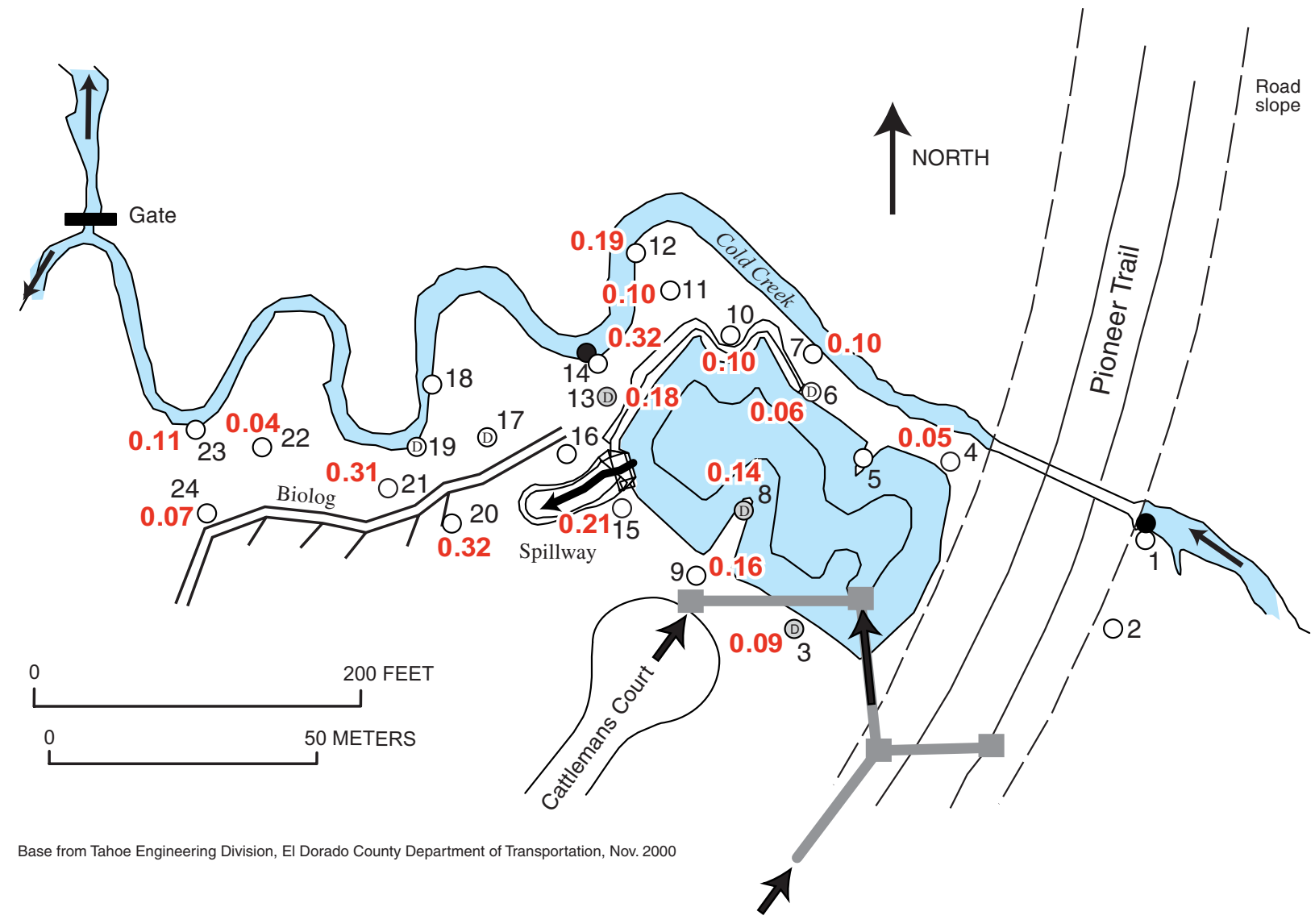

\section{EXPLANATION}

0.31 Dissolved phosphorus - In milligrams per liter

Ground-water level recorder

- Surface-water level recorder

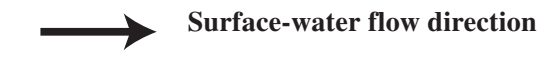

Stormwater drain

$24 \bigcirc$ Shallow monitoring well and well number (D indicates an adjacent deep well)

Figure 17.-Continued 
C Dissolved organic carbon, late April-May 2001

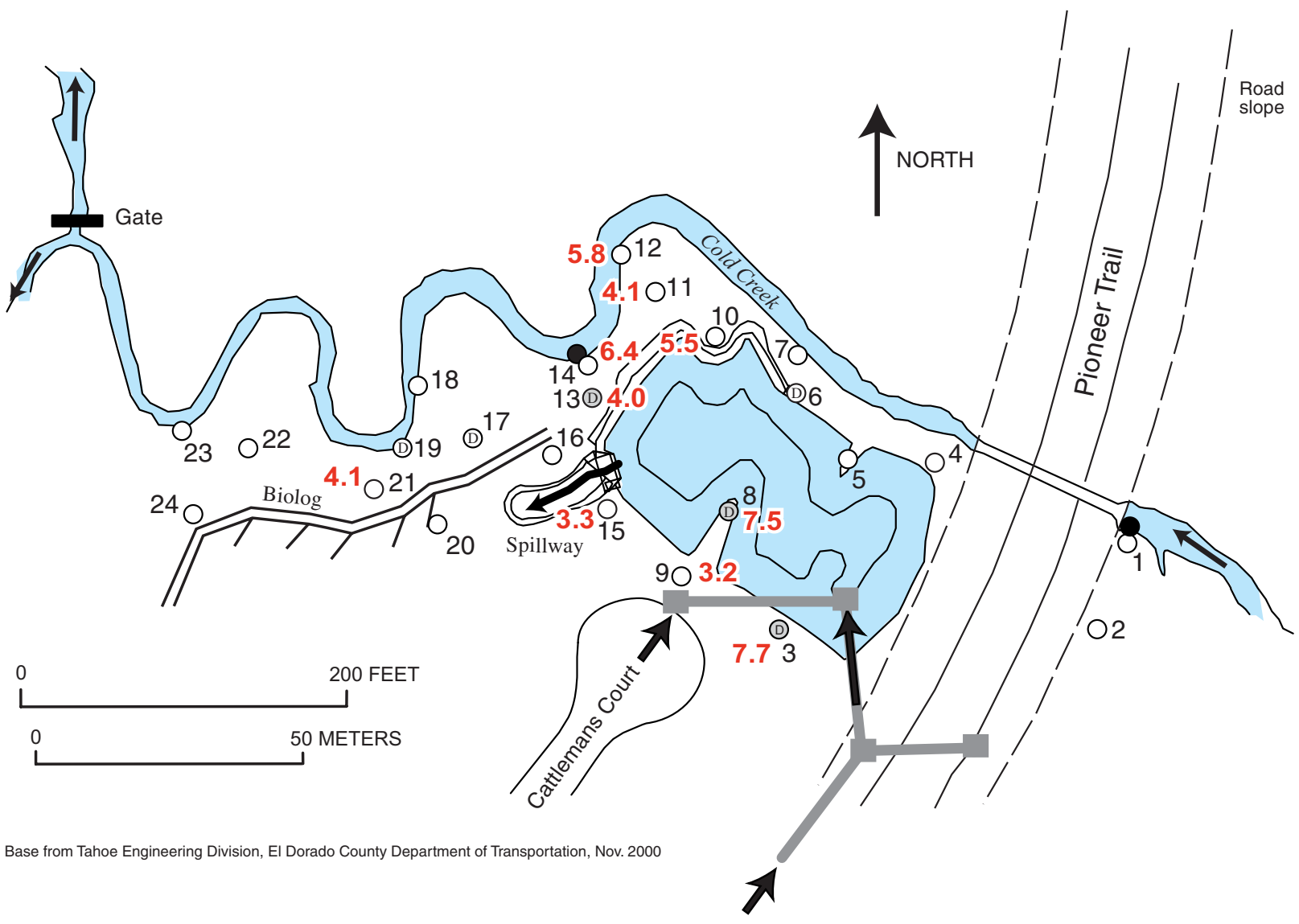

EXPLANATION

4.1 Dissolved organic carbon-In milligrams per liter

Ground-water level recorder

- Surface-water level recorder

$\longrightarrow \begin{aligned} & \text { Surface-water flow direction } \\ & \text { Stormwater drain }\end{aligned}$

$24 \bigcirc$ Shallow monitoring well and well number (D indicates an adjacent deep well)

Figure 17.-Continued. 

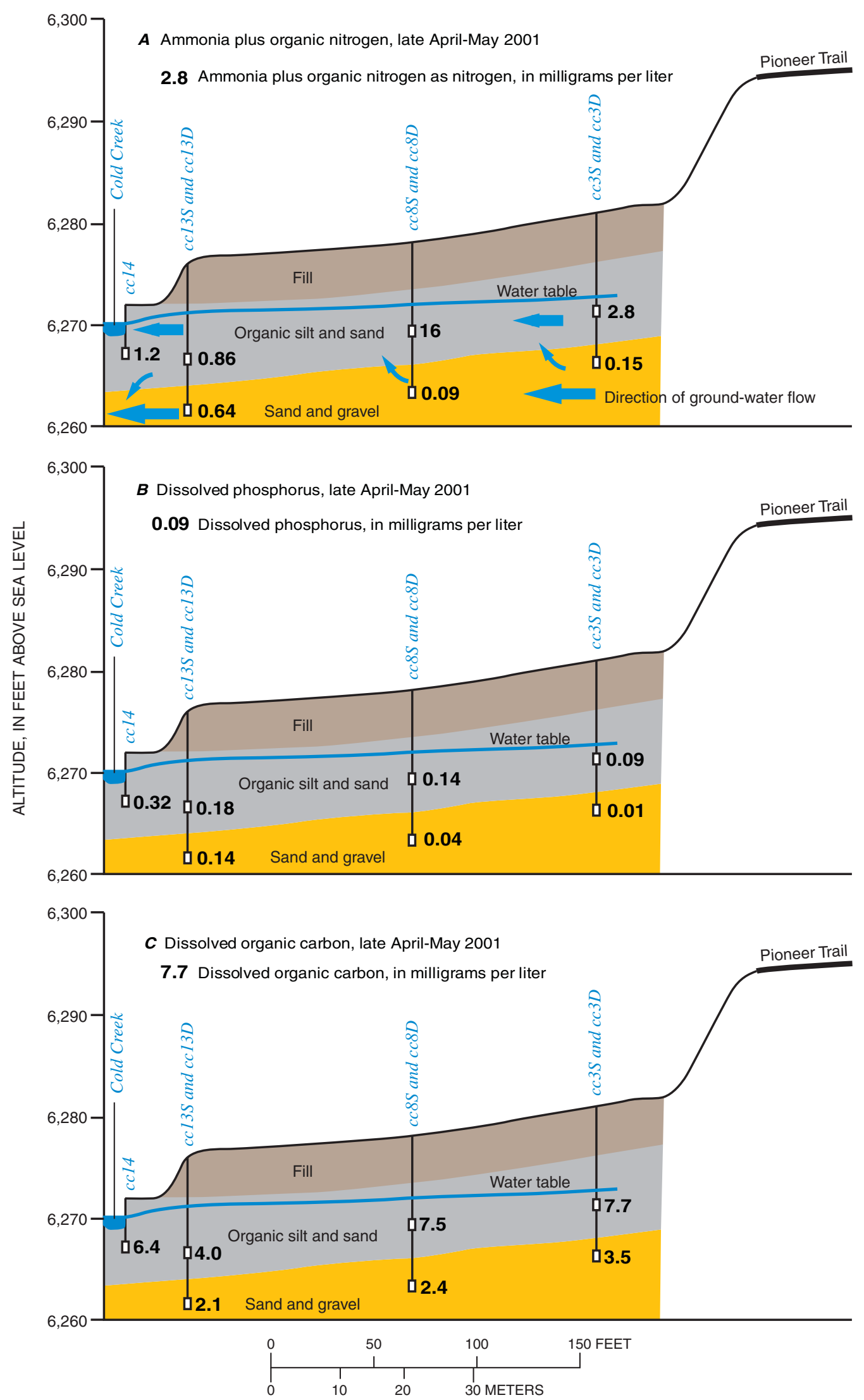

Figure 18. Vertical sections showing distribution of $(A)$ dissolved ammonia plus organic nitrogen, $(B)$ dissolved phosphorus, and $(C)$ dissolved organic carbon concentrations in ground water beneath Cattlemans detention basin prior to its construction, late April and May 2001. 


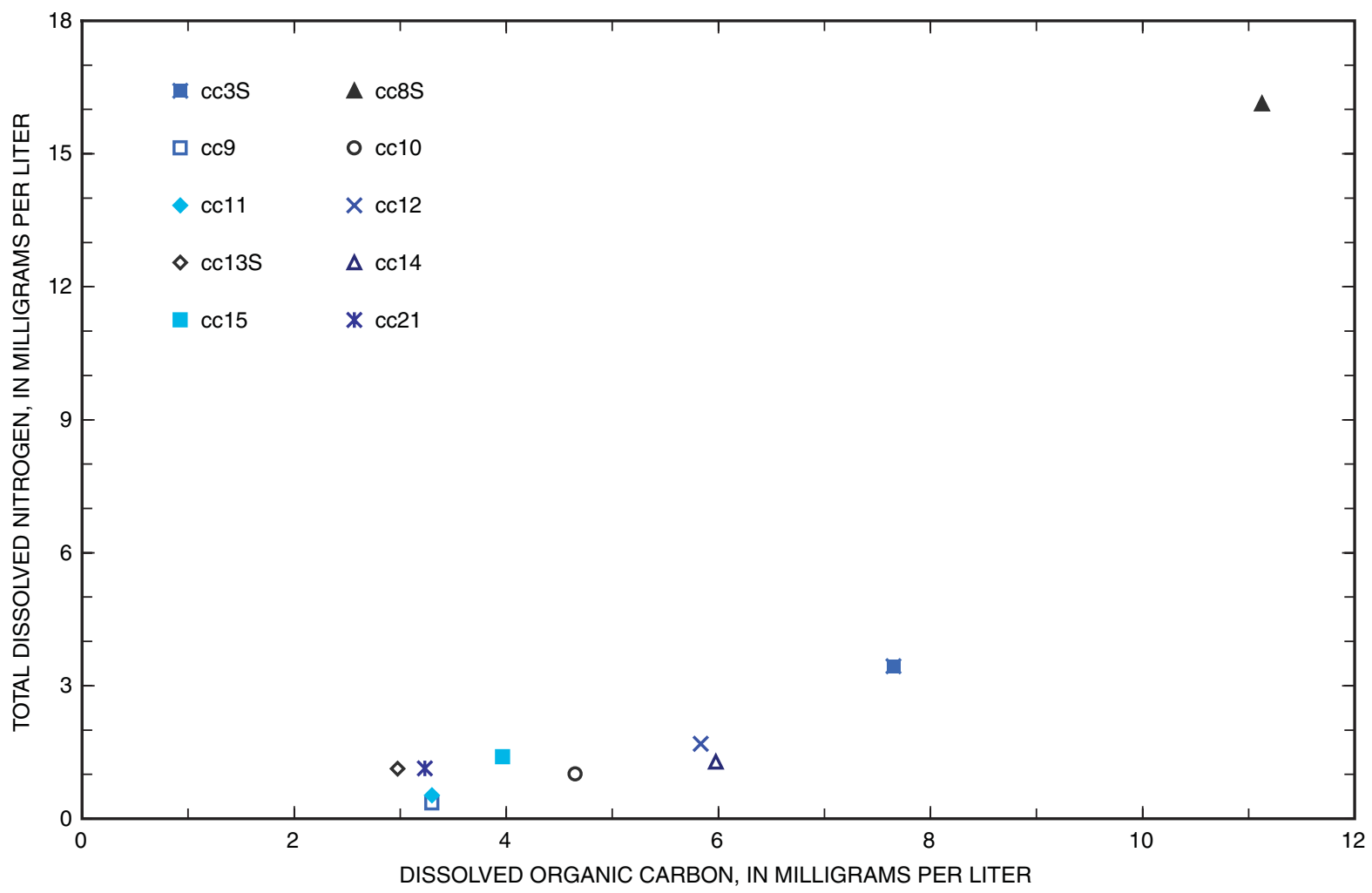

Figure 19. Relation between the mean concentration of dissolved organic carbon to mean concentration of total dissolved nitrogen in ground-water samples from the area of Cattlemans detention basin prior to and during its construction, January to November 2001.

Dissolved nitrate plus nitrite concentrations in ground water from the meadow deposits were consistently less than $0.33 \mathrm{mg} / \mathrm{L}$ as nitrogen. Ammonia and ammonia plus organic nitrogen (dissolved kjeldahl nitrogen) were consistently higher than dissolved nitrate plus nitrite throughout the year (fig. 22). Ammonia and ammonia plus organic nitrogen was highest in November at well cc3S (fig. 22A), whereas highest concentrations were observed in July at wells cc8S, cc13S, and cc14 (figs. 22B-D). Concentrations of ammonia plus organic nitrogen should always be greater than or equal to ammonia. This was the case for all analyses in which dissolved ammonia plus organic nitrogen concentrations were less than $1 \mathrm{mg} / \mathrm{L}$; however, for concentrations that exceeded $1 \mathrm{mg} / \mathrm{L}$, analytical results of dissolved ammonia plus organic nitrogen were occasionally less than ammonia. When the difference in concentrations exceeded the analytical error, the concentrations of dissolved ammonia plus organic nitrogen was assumed to equal the ammonia concentration. Analysis of ammonia had less variability among samples from the same well than did the ammonia plus organic nitrogen, thus the error in the analysis was assumed to be in the analysis for the ammonia plus organic nitrogen.

Dissolved phosphorus concentrations in all ground water were consistently lower in July than at the other sampled dates. The decrease in dissolved phosphorus in July may be the result of greater microbial activity in the unconsolidated deposits. Concentrations of dissolved phosphorus should always be greater than or equal to the concentration of orthophosphorus. Similar to ammonia, an occasional analytical result of orthophosphorus was greater than that of dissolved phosphorus. When the difference in concentrations exceeded the analytical error, the concentration of dissolved orthophosphorus was assumed to equal the dissolved phosphorus. For example, the July sample from well cc14 had a dissolved orthophosphorus concentration greater than the concentration of dissolved phosphorus plus the analytical error. The concentration of orthophosphorus in the well exceeded all other analyses from the well and all analyses for that date. Consequently, the orthophosphorus was set equal to the dissolved phosphorus.

Dissolved nitrogen concentrations were much lower in the deeper sand and gravel than in the meadow deposits (figs. 22 and 23). Although ammonia plus organic nitrogen concentrations were the predominant form of nitrogen, concentrations did not exceed $0.6 \mathrm{mg} / \mathrm{L}$ as nitrogen. Ammonia plus organic nitrogen concentrations were highest in November 2001 at wells cc3D and cc8D (fig. 23A and $B$ ), and were highest in January at well cc13D (fig. 23C). Dissolved phosphorus concentrations were lowest in July, and showed the same pattern as ground water from wells in the meadow deposits. Orthophosphorus generally follows the same trend as dissolved phosphorus. 

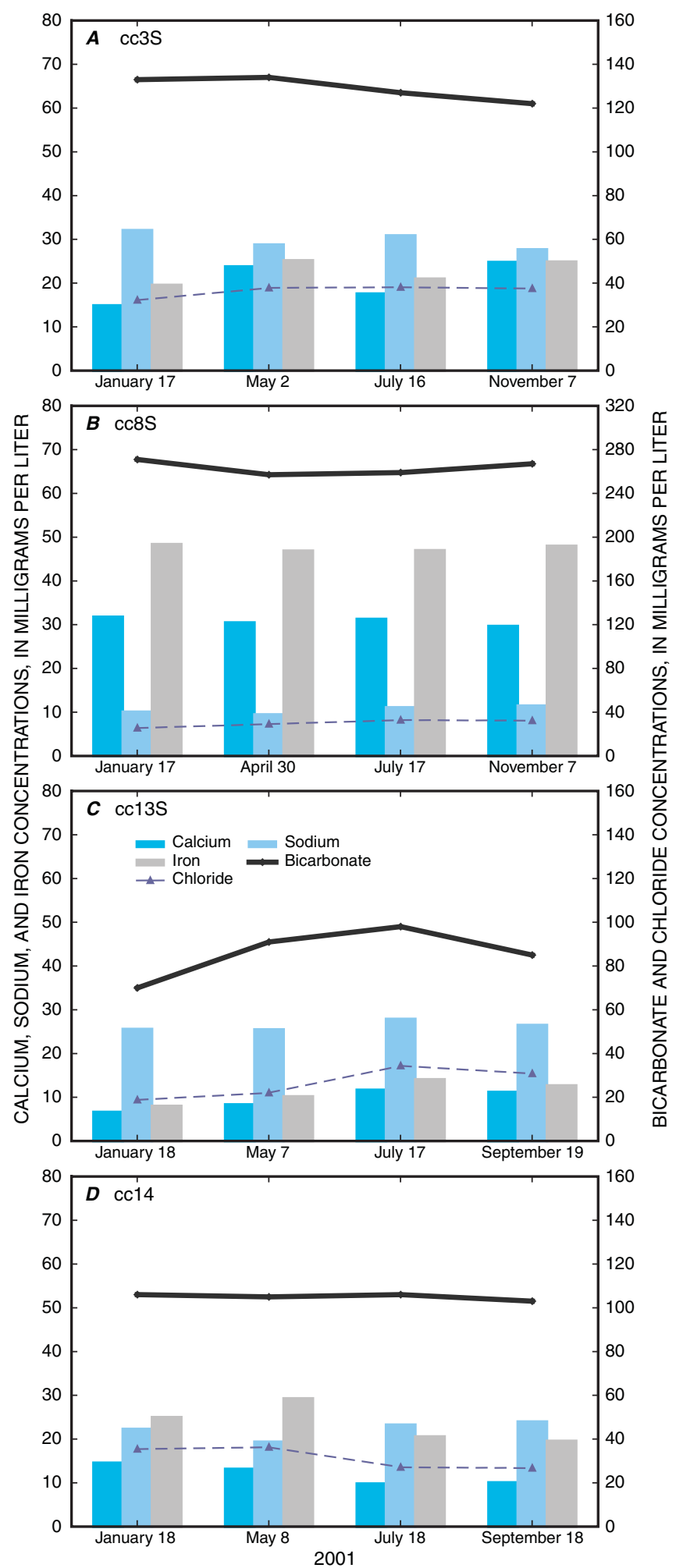

Figure 20. Graphs showing trends of major dissolved constituents in ground water from meadow deposits in the area of Cattlemans detention basin prior to and during its construction, January to November 2001.
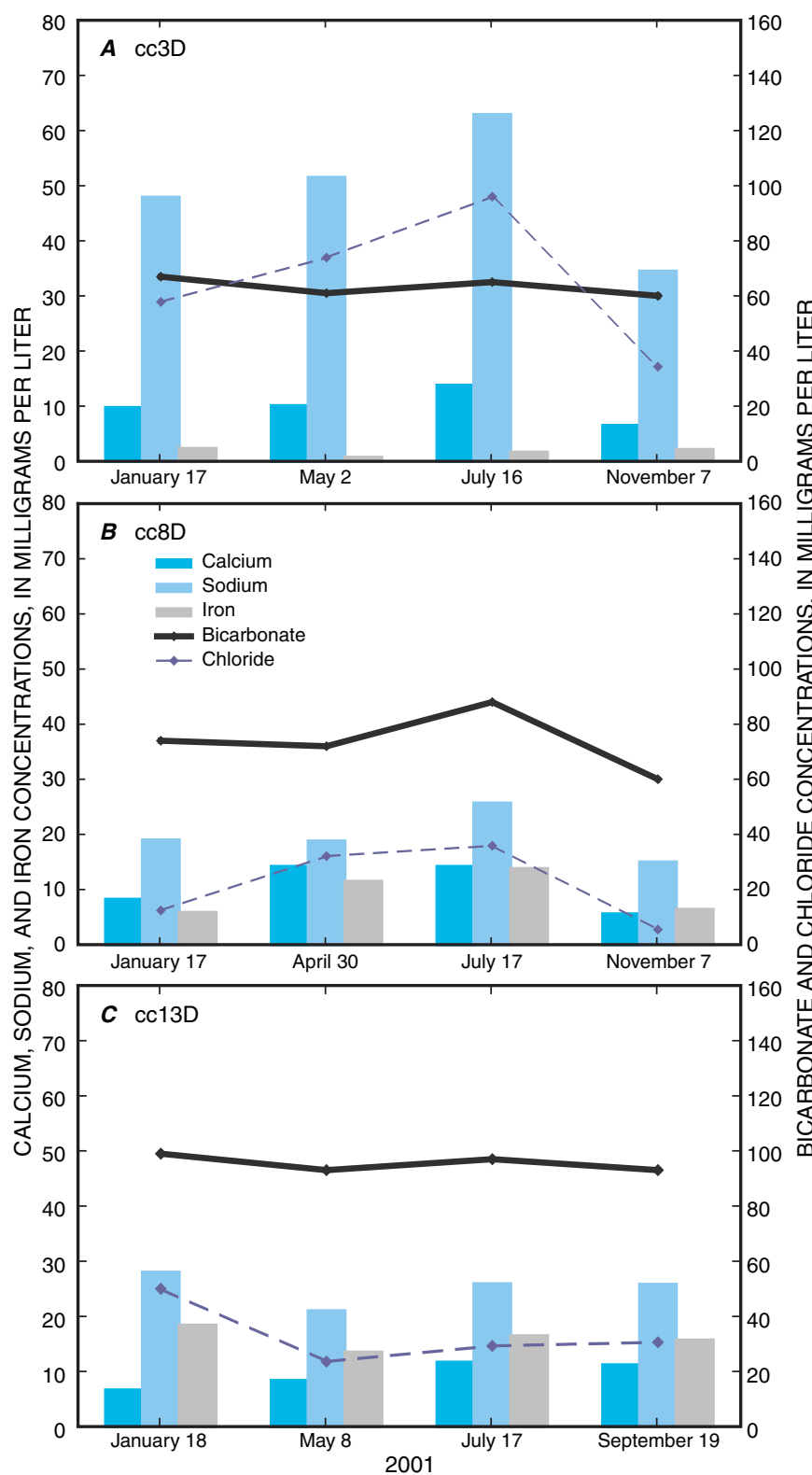

Figure 21. Graphs showing trends of major dissolved constituents in ground water from deeper sand and gravel in the area of Cattlemans detention basin prior to and during its construction, January to November 2001. 

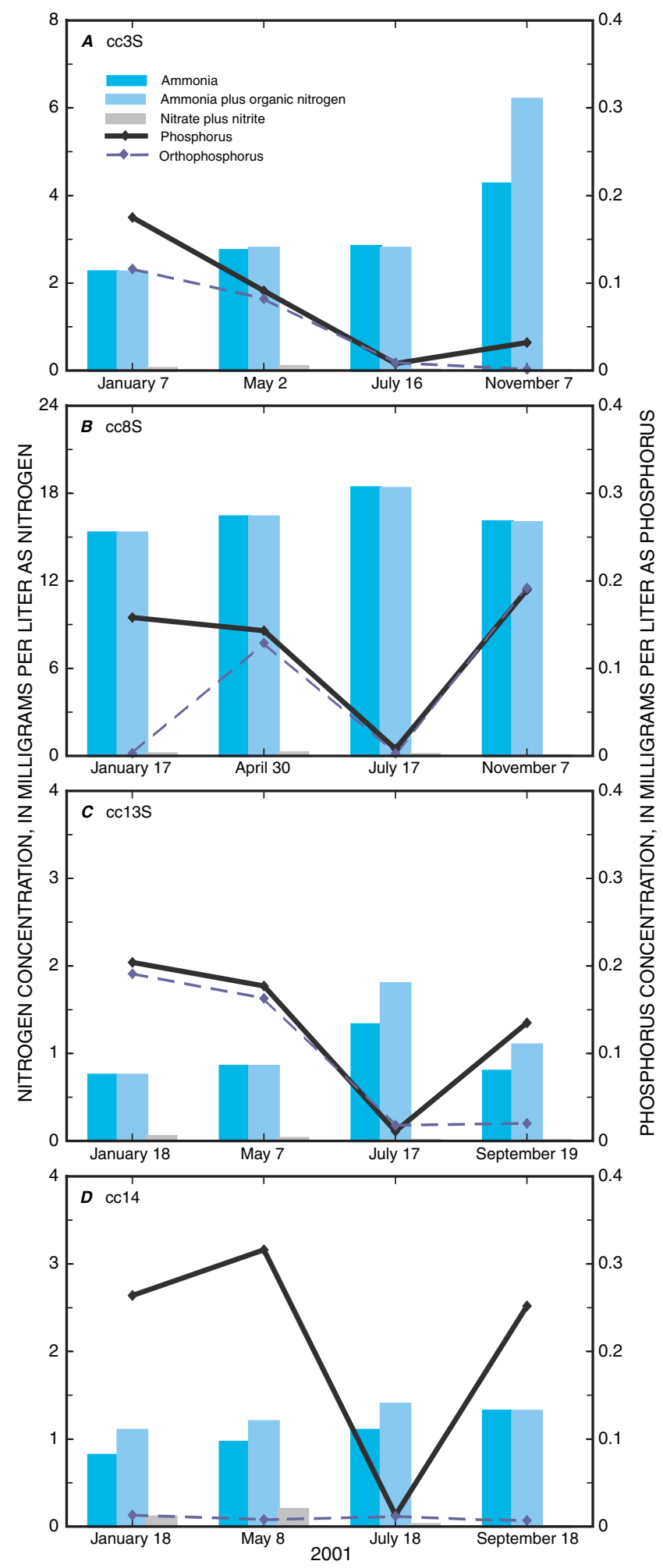

Figure 22. Graphs showing trends of dissolved nitrogen and phosphorus in ground water from meadow deposits in the area of Cattlemans detention basin prior to and during its construction, January to November 2001.

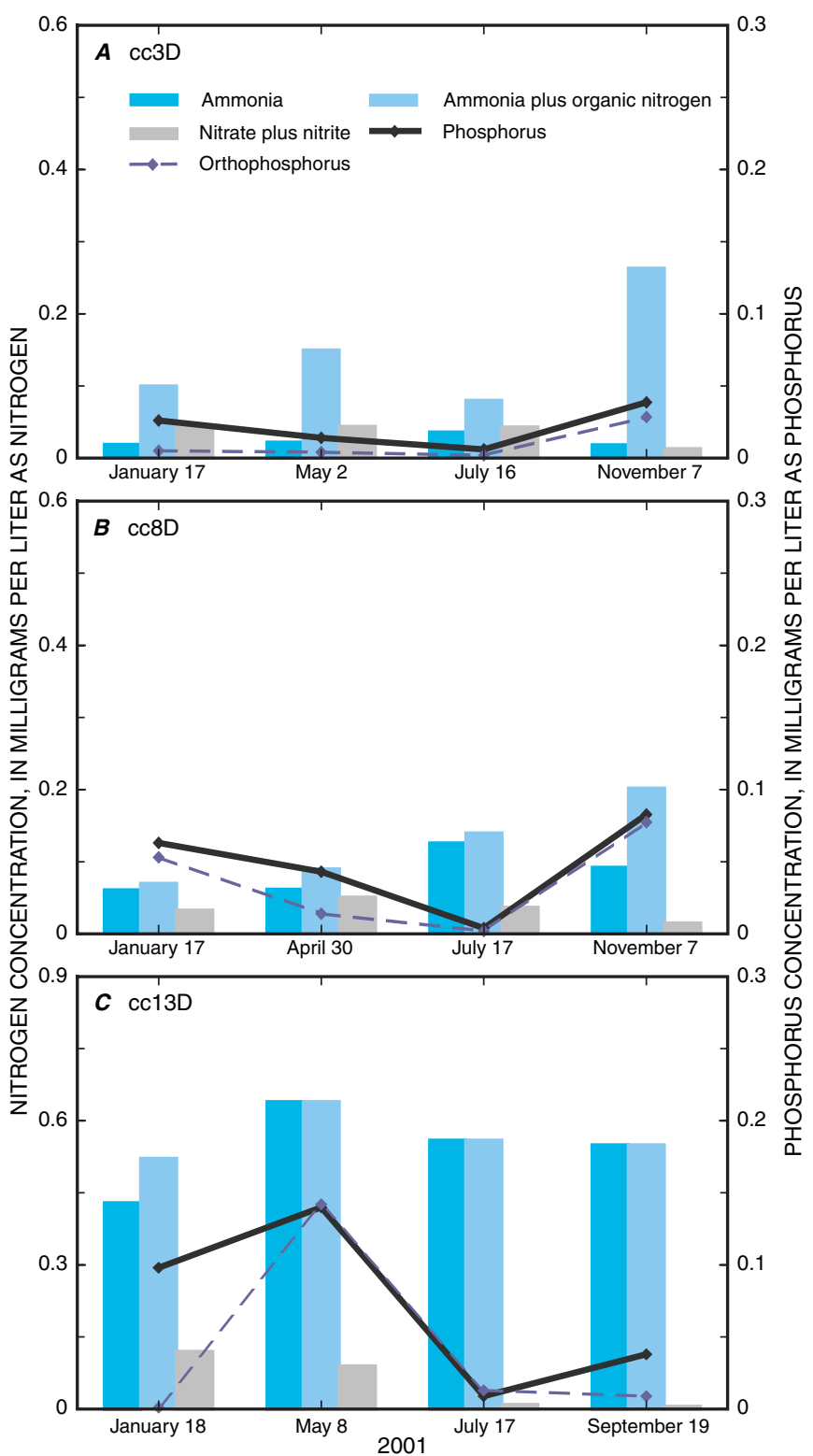

Figure 23. Graphs showing trends of dissolved nitrogen and phosphorus in ground water from deeper sand and gravel in the area of Cattlemans detention basin prior to and during its construction, January to November 2001. 
Dissolved organic carbon concentrations were highest in November 2001 at wells cc3S, cc8S, and cc3D (fig. 24). The higher organic carbon concentrations in wells cc3S and cc3D coincided with higher dissolved ammonia and organic nitrogen concentrations compared with samples collected earlier (figs. $22 A$ and $23 A$ ). The wells were sampled after the construction of the detention basin and following one storm that produced runoff from Pioneer Trail and Montgomery Estates subdivision on September 25, 2001. The runoff produced a rapid increase in water levels in wells cc3S, cc8S, cc3D, and cc8D (fig. 11A). The quality of the runoff that entered the newly constructed basin was unknown because the automatic flow meter and sampler had not been installed. It is possible that this water may have resulted in an increase in both dissolved organic carbon and nitrogen concentrations at wells cc3S and cc3D; however, dissolved ammonia plus organic nitrogen concentration decreased from July to November 2001 at well cc8S, which is inconsistent with the increase in dissolved organic carbon. Variations in concentrations and changes in concentrations of nutrients in ground water beneath the detention basin suggest that factors other than the transport of nutrients from the detention basin through ground water to Cold Creek may be important in evaluating the effectiveness of the detention basin.

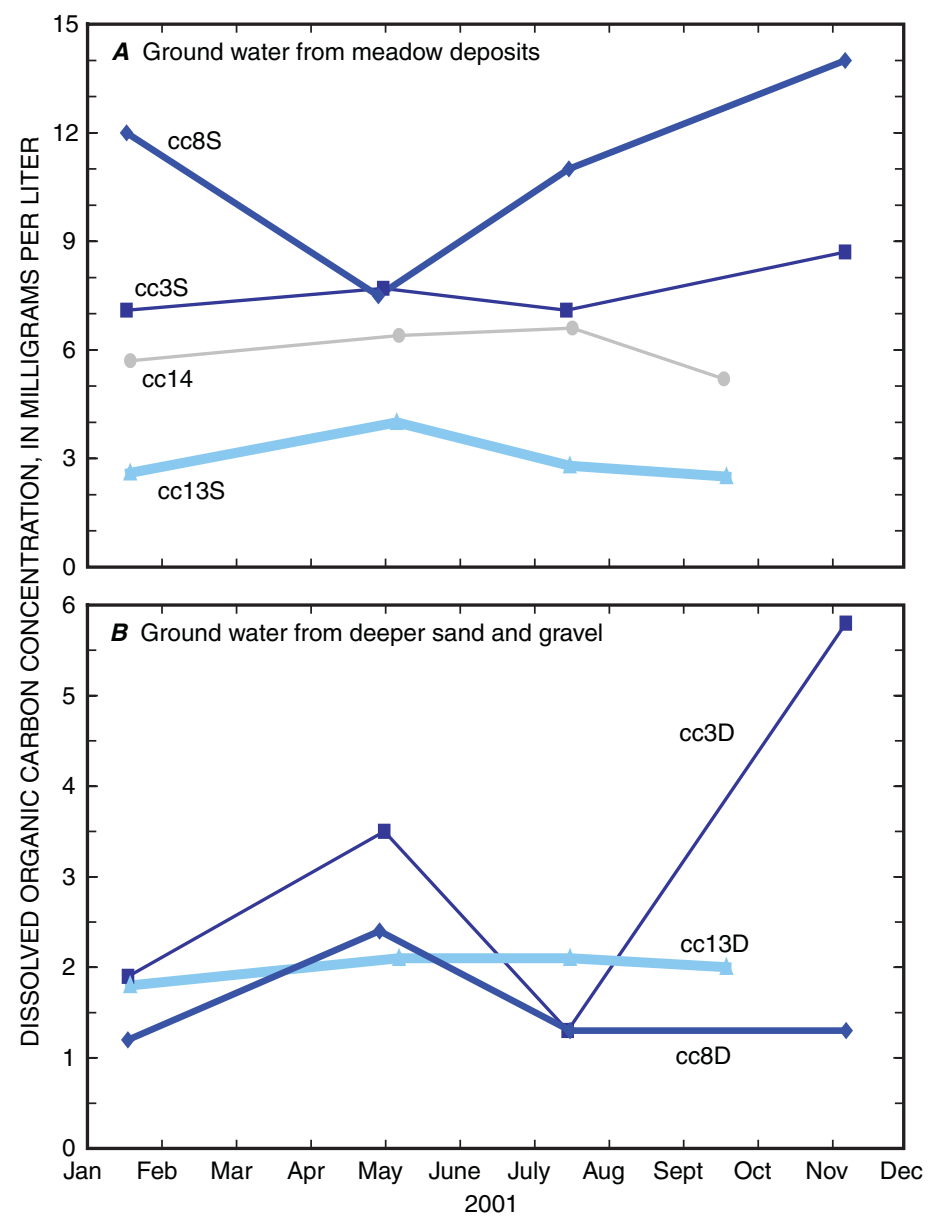

Figure 24. Graphs showing trends of dissolved organic carbon in ground water in the area of Cattlemans detention basin prior to and during its construction, January to November 2001.

\section{Summary and Conclusions}

Detention basins are used in the Lake Tahoe area to reduce sediment and nutrient loads from urban runoff. Ground water beneath detention basins may provide avenues for transport of dissolved nutrients to nearby streams and thence to Lake Tahoe. A study was initiated in November 2000 in cooperation with the Tahoe Engineering Division of the El Dorado County Department of Transportation to determine if nutrients in a detention basin are transported by ground water to a nearby stream. The area being studied is the Cattlemans detention basin, which was constructed in a meadow adjacent to Cold Creek in South Lake Tahoe, California. This report summarizes data collected prior to construction of the detention basin.

Thirty wells were installed in the area of the detention basin during November and December 2000, 10 months prior to construction of the detention basin in late August and September 2001. The wells were used to determine the direction of ground-water flow and to collect samples for analyses of dissolved ions and nutrient concentrations. Nutrient and sediment loads also were determined from urban runoff. The data collected prior to construction of the detention basin provide a basis for evaluating changes in sediment and nutrient loads to Cold Creek resulting from the detention basin.

The area where the detention basin was constructed has been altered by human activity several times. These activities include: altering the channel of Cold Creek at least twice; placement of fill across the meadow in the area of the detention basin; and construction of residences in the upland areas adjacent to the meadow. Excavation of a new channel for Cold Creek in 1994 below the natural water table likely increased ground water exchange along the channel, particularly in areas where meanders were constructed perpendicular to the direction of ground-water flow. The placement of fill across the meadow during construction of the nearby residences in the mid-1970's likely affected runoff, infiltration, and groundwater chemistry in the area of the detention basin.

Unconsolidated deposits were categorized into three classes: (1) fill material consisting of a red-brown loamy sand with some gravel and an occasional cobble; (2) meadow deposits of gray silt and sand with stringers of coarse sand and fine gravel; and (3) deeper brown to yellow-brown sand and gravel with lenses of silt and sand. Ground water prior to construction of the detention basin generally flowed from Pioneer Trail in a west to northwest direction toward two meander bends on Cold Creek that trended perpendicular to the direction of groundwater flow. The direction of ground-water flow remained the same all year, although ground-water levels were higher during the spring and early summer than during the fall and winter.

Total dissolved solids were generally higher in ground water from the meadow deposits than from the deeper sand and gravel. The principle dissolved constituents are calcium, sodium, bicarbonate, and chloride. Dissolved iron concentrations in ground water from the meadow deposits can exceed 
those of calcium and sodium. Concentrations of dissolved constituents in ground water generally had a greater range in the meadow deposits compared with the deeper sand and gravel. Concentrations of dissolved iron and chloride were 500 and 30 times higher, respectively, in ground water from the meadow deposits than dissolved concentrations in Cold Creek. The high concentrations of dissolved iron (median concentration of $15 \mathrm{mg} / \mathrm{L}$ ) and the lack of dissolved oxygen (generally below the detection limit of $0.3 \mathrm{mg} / \mathrm{L}$ ) indicate that ground water in the meadow deposits is anoxic. The lack of oxygen is likely caused by microbial oxidation of organic matter. The source of chloride (median concentration in the meadow deposits of $32 \mathrm{mg} / \mathrm{L}$ ) is most likely from the application of a mixture of cinders and salt on the surface streets during winter.

Nitrogen concentrations were generally higher in ground water from the meadow deposits than in ground water from the deeper sand and gravel. Higher concentrations of dissolved nitrogen correspond to higher concentrations of dissolved organic carbon. Ammonia plus organic nitrogen were the dominant forms of dissolved nitrogen and ranged from 0.04 to $18 \mathrm{mg} / \mathrm{L}$ as nitrogen. Ammonia plus organic nitrogen concentrations were highest in the middle of the area where fill covered the meadow deposits. Nitrate plus nitrite concentrations were low $(<0.33 \mathrm{mg} / \mathrm{L})$ throughout the area. Dissolved nitrogen and organic carbon did not show a consistent change in the direction of ground-water flow. This suggests that nitrogen concentrations in ground water are controlled by chemical and biological reactions within the meadow deposits.

Dissolved phosphorus concentrations ranged from 0.004 to $0.4 \mathrm{mg} / \mathrm{L}$ and were similar in ground water from both the meadow deposits and the deeper sand and gravel. Concentrations of phosphorus generally increased in the direction of ground-water flow. Consequently, dissolved phosphorus was lower in ground water from well cc3S on the east side of the detention basin and higher at well cc14 on the west side next to Cold Creek. This suggests that the dissolved phosphorus concentrations in ground water are controlled by dissolution of minerals in the unconsolidated deposits. Dissolved phosphorus concentrations decreased throughout the area in July. This decrease may be the result of greater microbial activity in ground water or from the uptake by roots during the summer.

In conclusion, nitrogen, phosphorus, and iron are dissolved in ground water beneath the area of the planned detention basin in sufficient concentrations that could affect nutrient concentrations in Cold Creek or in the streambed sediments. Although the expected result of excavating a detention basin adjacent to Cold Creek is to reduce nutrient loads into Cold Creek from urban runoff by capturing sediments, the detention basin potentially could increase ground-water flow through the meadow deposits by inducing greater recharge whenever the detention basin is filled with runoff.

\section{References Cited}

Allander, K.K., 2003, Trout Creek-Evaluating ground-water and surface water exchange along an alpine stream, Lake Tahoe, California, in Stonestrom, D.A., and Constantz, Jim, eds., Heat as a tool for studying the movement of ground water near streams: U.S. Geological Survey Circular 1260, chap. 6, p. 35-45.

Barthelmes, A.J., 1946, Application of continuous profiling to refraction shooting: Geophysics, v. 11, no. 1, p. 24-42.

Bonham, H.F., Jr., and Burnett, J.L., 1976, Geologic Map, South Lake Tahoe Folio: University of Nevada, Reno, Nevada Bureau of Mines and Geology, Environmental Series Map 2Ag, scale 1:24,000.

Church, P.E., and Friesz, P.J., 1993, Effectiveness of highway drainage systems in preventing road-salt contamination of groundwater-Preliminary findings: Transportation Research Board, National Research Council, Washington, D.C., Transportation Research Record No. 1420, p. 56-64.

Crippen, J.R., and Pavelka, B.R., 1970, The Lake Tahoe basin, California-Nevada: U.S. Geological Survey Water-Supply Paper 1972, 56 p.

Fenske, J.P., 1990, Erosion control and water quality in the Tahoe basin, California-Nevada: University of Nevada, Reno, Mackay School of Mines, M.S. thesis, 155 p.

Feth J.H., Roberson, C.E., and Polzer, W.L, 1964, Sources of mineral constituents in water from granitic rocks, Sierra Nevada, California and Nevada: U.S. Geological Survey Water-Supply Paper 1535-I, 70 p.

Glancy, P.A., 1988, Streamflow, sediment transport, and nutrient transport at Incline Village, Lake Tahoe, Nevada, 197073: U.S. Geological Survey Water-Supply Paper 2313, 53 p.

Goldman, C.R., 1988, Primary productivity, nutrients, and transparency during the early onset of eutrophication in ultraoligotrophic Lake Tahoe, California-Nevada: Limnology and Oceanography, v. 33, p. 1321-1333.

Goldman, C.R. and Byron, E.R., 1986, Changing water quality at Lake Tahoe: The first five years of the Lake Tahoe Interagency Monitoring Program: University of California, Davis, Tahoe Research Group, Institute of Ecology, 12 p.

Granato, G.E., Church, P.E., and Stone, V.J., 1995, Mobilization of major and trace constituents of highway runoff in groundwater potentially caused by deicing chemical migration: Washington, D.C., National Research Council, Transportation Research Record 1483, p. 92-104.

Harrill, J.R., 1977, Hydrologic Map, South Lake Tahoe Folio: University of Nevada, Reno, Nevada Bureau of Mines and Geology, Environmental Series Map 2Af, scale 1:24,000.

Hydro Science, 2000, Bioavailable nutrient loading into Lake Tahoe and control opportunities with an emphasis on utilizing SEZS to treat urban runoff: Vacaville, California, Final Draft Report to Tahoe Regional Planning Agency, 93 p. 
K.B. Foster Civil Engineering, Inc., 1989, Ski run water quality improvement project: Carnelian Bay, California, Environmental Assessment Report, 70 p.

Martin, E.H., 1986, Effectiveness of an urban runoff detention pond-wetland system: Journal of Environmental Engineering, v. 114, p. 810-827.

Pakiser, L.C., and Black, R.A., 1957, Exploring for ancient channels with the refraction seismograph: Geophysics, v. 22, no. 1, p. $32-47$.

Reuter, J.E., Djohan, Tjut, and Goldman, C.R., 1992a, The use of wetlands for nutrient removal from surface runoff in a cold climate region of California-Results from a newly constructed wetland at Lake Tahoe: Journal of Environmental Management, v. 36, p. 35-53.

Reuter, J.E., Marzolf, E.R., and Goldman, C.R., 1992b, Water quality treatment of surface runoff in a natural subalpine meadow: Case study from the Lake Tahoe basin, California: Reno, Nevada, International Erosion Control Association, Proceedings of Conference XXIII, February 18-21, 1992, The Environment is Our Future, p. 17-35.
Rowe, T.G., and Allander, K.K., 2000, Surface- and groundwater characteristics in the Upper Truckee River and Trout Creek watersheds, South Lake Tahoe, California and Nevada, July-December 1996: U.S. Geological Survey Water Resources Investigations Report 00-4001, 39 p.

Scott, J.H., 1993, SIPT2-A personal computer program for interpreting seismic refraction data using modeling and terative ray tracing techniques: Golden, Colorado, Rimrock Geophysics, Inc., 12 p.

Scherger, D.A., and Davis, J.A., 1982, Control of stormwater runoff pollutant loads by a natural wetland and retention basin: University of Kentucky, Lexington, Proceedings, International Symposium on Urban Hydrology, July 27-29, 1982, Hydraulics and Sediment Control, p. 109-123.

Telford, W.M., Geldart, L.P., Sheriff, R.E., and Keys, D.A., 1976, Applied geophysics: Cambridge, Cambridge University Press, $860 \mathrm{p}$.

Yu, S.L., Earles, T.A., and Fitch, G.M., 1998, Aspects of functional analysis of mitigated wetlands receiving highway runoff: Washington, D.C., National Research Council, Transportation Research Record 1626, p. 21-30. 
Since 1879, the U.S. Geological Survey has been providing maps, reports, and information to help others who manage, develop, and protect our Nation's water, energy, mineral, land, and biological resources. We help find natural resources, and we supply scientific understanding needed to help minimize or mitigate the effects of natural hazards and the environmental damage caused by human activities. The results of our efforts touch the daily lives of almost everyone. 